F 1130

.D33

Copy 1

( 


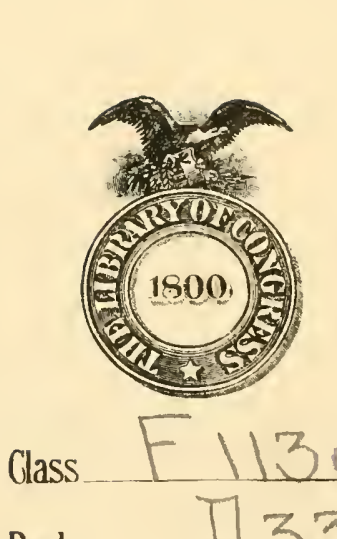






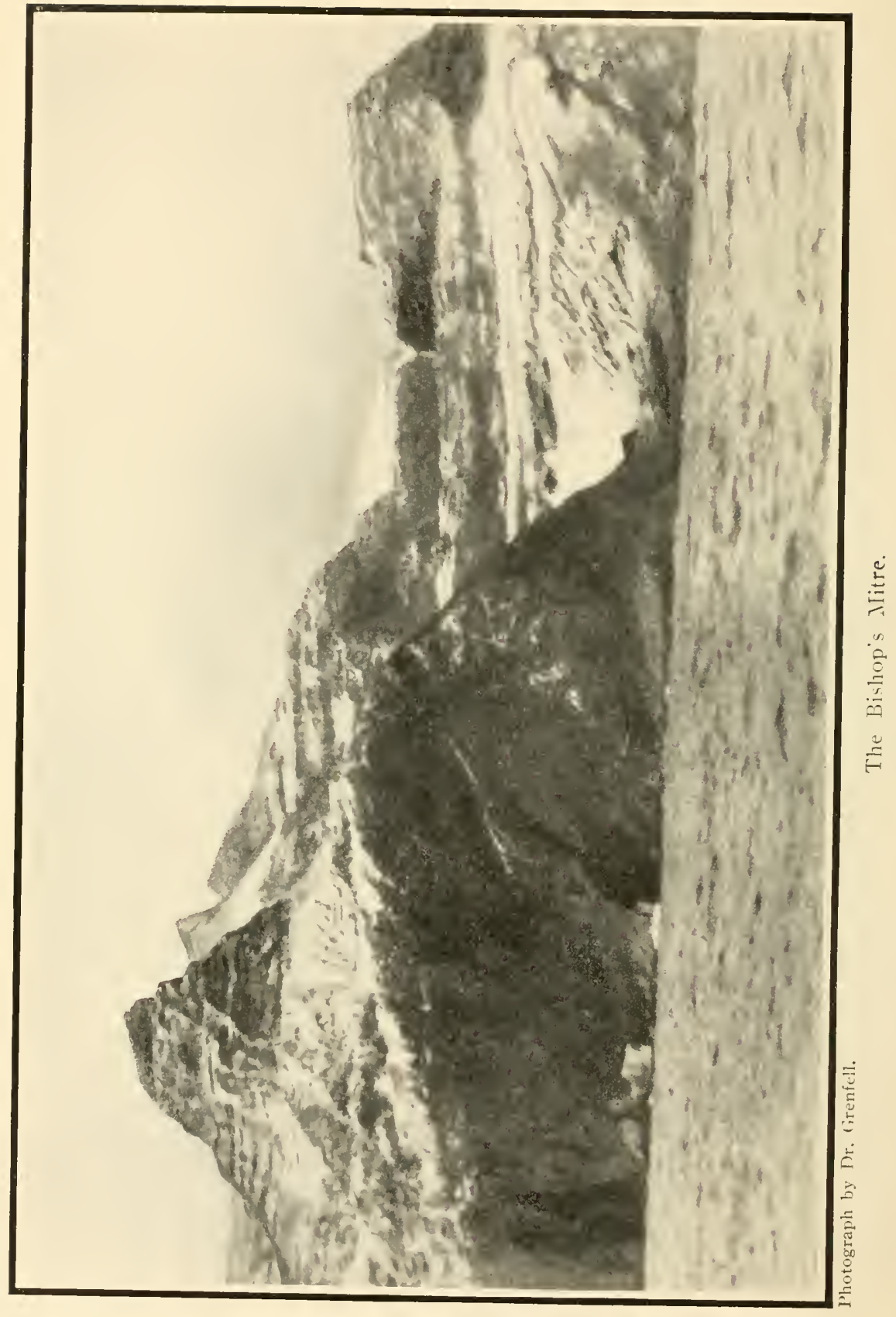




\section{REPORT}

OF THE

\section{Brown-Harvard Expedition}

TO

Nachvak, Labrador

I 900

BY

E. B. DElabarRE, Ph. D. 
F 1136

.1 33

367852
27

$\because \vdots$ 


\section{BULLETIN OF THE \\ Geographical Society \\ OF PHILADELPHIA}

VOL. III

APRIL, 1902

NO. 4

Report of the Brown-Harvard Expedition to

Nachvak, Labrador, in the year 1900.

BY

E. B. DELABARRE, PH. D.,

Professor of Psychology in Brown University.

Introduction. - I. Outline of the Voyage. - II. Summary of the Voyage, and Meteorological Conditions.-III. Overland from Hebron to Nachvak. - IV. Nachvak Bay and the Ascent of Mount Faunce. V. Scenery of the Atlantic Coast of Labrador.-VI. Life on the Labrador Coast.-VII. Scientific Results of the Expedition.-VIII. Report on Botany.-IX. Report on Ornithology.-X. Report on Geology.

INTRODUCTION.

This is the record of an expedition of very modest proportions and aims. As explorers none of the party had had previous experience; and only two were experts in the line of work they undertook, both of them young in their respective professions. These facts account for much that must necessarily appear as of a more or less amateurish character in our work and report. The results accomplished in spite of these disadvantages, however, which have largely exceeded our anticipations, show how large a field for further profitable research still awaits the explorer. Large sections of the coast are still without a first crude charting of any degree of accuracy; and the entire coast is much in need of thorough work of this kind. Great ranges of the loftiest mountains on our 
Atlantic seaboard offer a tempting and untrodden ground for topographical and geological investigation. The botanist, the zoölogist, and doubtless the scientific worker in many other lines, may confidently expect many important discoveries to reward his labors.

Some of our results have already been published. Mr. Bigelow's report on Ornithology appears in $A u k$, I902, Vol. XXVII, pp. 24-3I ; and Dr. Daly's account of the geology of the coast in the Bulletin of the Museum of Comparative Zoölogy at Harvard College, 1902, Vol. XXXVIII, pp. 205-270. Each of them has contributed a section to the present report, briefly summarizing his results. Dr. Daly's report is accompanied by a number of illustrations, for the most part of a more purely geological interest than those given herewith. It embodies by far the most important results of our expedition; and it emphasizes at greater length than I have done the need of further exploration.

Local names and their spelling, as given in this report, cannot in all cases be taken as final and authoritative. There is need of revision in this whole matter, and the final solution must be left to the future. This is true particularly of the names of the less prominent rivers, mountains, and localities in the more northerly parts of the country. It is not unnatural that a considerable variety in usage should have arisen. Some names are due to the Newfoundland fishermen, of English descent. Some were given by German missionaries, and these have been Anglicized to some extent. A large proportion are of Eskimo origin, and their orthographic rendition is due partially to English sources, more largely to the German missionaries, whose spellings in some cases have been variously and doubtfully modified to suit the demands of English 
phonetics. Our authorities for the names were the various charts, the Nerufoundland and Labrador Pilot, Mr. George Ford, of Nachvak, and Rev. Wolf Stecker, of Ramah. Dr. Daly, in his report, has used the versions of the latter, whom he regards as "the only one I have come across who can give authoritative opinions on Eskimo." I should have preferred to have used the same spellings and forms in all cases as Dr. Daly : but unfortunately his report has come to me too late to make the necessary changes in my text, and I was previously unaware of the names as given by Stecker. The differences are not numerous, and apply almost exclusively to the region about Nachvak, for which $I$ have used names as given by Mr. Ford. I call attention in footnotes to the most important of the variations.

To Professor Packard and President Faunce, of Brown University, and President Eliot, of Harvard, I apologize for the use of their names as designations of mountains. The exaggerations of certain unauthorized newspaper accounts soon after our return may have given them unpleasant associations, but I trust that these may have long since disappeared. Dr. Daly, in his map of Nachvak Bay, reproduced herewith, shows two of these mountains, but does not use their names; and he writes me that "the mountains are really not sufficiently prominent even in Labrador to merit those particular names." It is true that there are loftier summits in Labrador, and that had we found and climbed them we should have reserved these names for the worthiest of them. But they were the highest unnamed peaks with which we came into intimate contact; as will be seen from my frequent descriptive and botanical references to them, it was essential to give them some distinctive label; and we hope that the 
men whom we, as college students and professors, honor and esteem most highly, will not resent the liberty we have taken in a spirit of sincerest admiration and respect.

I gladly express my indebtedness to the many who have been of aid to me in connection with the preparation and material of this report. Mr. Henry G. Bryant very kindly allows me to reproduce his map of Labrador. The generosity of Dr. Daly and of the Museum of Comparative Zoölogy at Harvard College make it possible to present Daly's Map of Nachvak Bay. To Dr. Daly and Mr. Adams I owe the privilege of including some of their photographs with my own; and to Dr. Grenfell that of making use of the photograph given as frontispiece. To the publishers of Outing I am indebted for the cuts showing the Eskimos at Pangnertok, and the party on the overland trip from Hebron to Nachvak. The editors of the Providence Journal and of the Brunonian permit me to use again in two of my sections material which was contributed originally to their publications. To Professor Bailey and Mr. Collins I cannot sufficiently express my gratitude for their aid in the identification of botanical specimens. Without the large amount of time and energy they have willingly devoted to this task, my own work on the expedition would have been valueless. To a large degree, also, I am under obligation to Professor Cummings, Professor Farlow, Professor Packard, Professor Robinson, and Professor Rowlee for similar services.

Finally, and not the least heartily, I express my grateful appreciation to the Geographical Society of Philadelphia for its courtesy in permitting the use of its pages for my report; and to its Secretary, Mr. Greene, for his invaluable help and advice in the work of publication. 
OUTLINE OF THE VOYAGE.

The coast of Labrador is distant from us only about a week's journey, and in its southern parts is easily accessible by aid of regularly running steamers. Its brief summers possess the attractiveness of our own autumnal season. Its scenery is magnificent, full of beauty and grandeur, distinguished by including the highest mountains on the entire Atlantic side of America, and in other ways also rivaling that of many more frequently visited regions. Its reputation as a cold, forbidding, desolate, and dangerous country is unjust. Though forests are lacking near the coast, yet it has the charm of an abundant vegetation, giving it color and life without concealment of the glory of form belonging to its rocky and lofty mountains. It supports a considerable population, both native and white. It is visited annually by hundreds of fishermen from Newfoundland, to some of whom it is familiar even to its northern extreme. It has been explored by scientists to a considerable extent, and traversed by them in various directions. Yet, in spite of these facts, it remains comparatively unknown to most people and attracts few visitors; and scientific expeditions can still add much to knowledge concerning it.

Huntington Adams, an undergraduate of Harvard, accompanied the expedition made by Mr. Taber in 1899 in search of Eskimos for the Paris Exposition of I900. He returned full of enthusiasm for the beauty of the country and eager to return to it for further exploration. He had learned that there was yet plentiful need of good scientific work throughout the peninsula. Much of the coast is still very 
inadequately charted. Almost all previous scientific expeditions have traversed the coast with such rapidity and touched at so few points that a large proportion of it has been very insufficiently examined, and its physiographic features and geological structure still lack accurate description. Interior exploration has been confined to comparatively few routes, and in particular the entire northern part of the peninsula, between Ungava Bay and the Atlantic, where exist probably the most elevated points of land on the eastern side of the continent, has never had its heights measured and other features determined. Mr. Adams's description of these opportunities for further research; his excellent photographs of the scenery; his representations of the game possibilities of the region; and a general desire to visit an unknown country and to lead an active, healthy, outdoor life for a short time, finally induced several other men to join him in an attempt to unveil some of the mysteries that still remain unsolved in connection with the Labrador peninsula.

The party, as finally organized, was composed of six members. Edmund B. Delabarre, Ph. D., Professor of Psychology in Brown University, was nominally leader of the expedition; in the absence of material sufficient to occupy him largely in his own specialty, he made a collection of plants and devoted his time for the most part to such examination of them as could be accomplished by one who is entirely an amateur in botanical work. Reginald A. Daly, Ph. D., Instructor in Geology in Harvard University, made a thorough and efficient geological and physiographical examination of the coast; prosecuted systematic studies of the temperature, salinity, and currents of the ocean, and sounded and charted Nachvak Bay. The other four men were all under- 
graduates from Harvard. Huntington Adams organized and provisioned the expedition most efficiently, kept the meteorological records, and studied the economic mineralogy of the regions visited. In the latter work he was assisted by Lewis B. McCornick. Henry B. Bigelow proved an excellent ornithologist. Henry W. Palmer engaged in no scientific work, but was attracted chiefly by the hope of sport and adventure.

On account of the limited resources of the party, the expedition was made in a sailing vessel instead of in a steamer. This subjected it to numerous delays and made the trip so slow that there was little time for the much desired exploration of the northern extremity of the country; but it proved a fortunate feature in that it insured a thorough and detailed examination of the coast greater than that of any previous scientific expedition.

The ship secured for the voyage was the "Brave," a forty-ton fishing schooner owned by J. M. Butler, of St. John's, Newfoundland. She had just been entirely rebuilt, and was therefore new and clean, and well adapted to the needs of our small party. Her captain was Abram Batten, of Bareneed, Conception Bay-a very efficient man, skillful and trustworthy, and thoroughly familiar with the Labrador coast. Besides him, our crew consisted of a cook and two seamen, to whose willing and able service we owe much of the success of the expedition. It may encourage other attempts similar to ours to know that all the regular expenses of the trip, including hire and provisioning of vessel, pay of captain and crew, and such extra equipment and provisioning as we ourselves furnished, anounted to only about $\$ 1,200$ for the entire party of six. 
We left St. John's at 2.30 in the afternoon of Monday, June 25 th. In beating out between the high cliffs that stand on either side of the narrow entrance to its magnificent harbor, the unsteady winds characteristic of the place nearly caused us to drift upon the rocks and thus end our trip at the very start. Outside we found a strong breeze from the south that sent us well along on our way before it began to fail in the evening. During the night and following day we made but little progress, and came to anchor in the harbor of Greenspond Island, in Bonavista Bay, at 8.30 in the evening of the 26th. A prolonged easterly gale detained us here five days. On July 2 d, at 3.45 A. M., we again got under way, anchored that night off Change Island, sailed through the next day and night, and at noon of July $4^{\text {th }}$ were off Cape Bauld, the northern extreme of Newfoundland. Fog and calms frustrated an attempt to continue across the Straits of Belle Isle, so we beat back and came to anchor in Kirpon Harbor, just to the west of Cape Bauld. The distance thus far from St. John's was about 330 miles.

At Kirpon Harbor we were imprisoned eight days by ice-floes. On the morning following our arrival we discovered that the Straits were filled with ice from one shore to the other, a width of some 25 miles, and in length as far as we could see. A day later the harbor also was blocked. A large number of other vessels-probably as many as three or four hundred, according to Captain Batten-were also detained in this and neighboring harbors, awaiting an opportunity to cross to the Labrador fishing grounds. We occupied the time in excursions over the ice and about the neighborhood on shore, and in familiarizing ourselves with the details of our scientific work. 


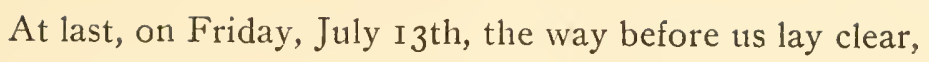
and we crossed to the Labrador coast, making our first anchorage that evening in St. Lewis Sound, between Hare Island and Little Caribou-a run of 43 miles. We went ashore at once on Great Caribou Island and made botanical and geological observations. Almost every subsequent evening during our trip, and many entire days, when unfavorable winds made it impossible to proceed, we had similar opportunities for work. Inasmuch as a summary of this work and a description of the scenery of the coast will be given in later pages, the chief features of the remainder of the trip may now be presented in very brief form, except when incidents of especial interest demand fuller detail.

July I 4.- Started at 5.30 A. M., but were unable to get outside of St. Lewis Sound on account of fog and of ice blocking the entrance. Return, and anchor off Assizes Island at 9.30 A. M., having sailed I 3 miles.

July I 5.-Ice-floes throughout the harbor. Remain at anchor, but row up St. Charles River for exploration and wood.

July 16.-No wind. Some of the party visit Battle Harbor.

July I7.-Start 4 A. M. and run 65 miles. Little ice, and much scattered. Anchor 6.30 P. M. in bight at southwest end of Seal Island.

July i 8.-Delayed by high north wind.

July 19.-North wind continues, and foggy. Some of the party row to Sloop Harbor and explore on the mainland.

July 20.-At II.30 A. M. again under way. Pass through considerable floe-ice. Much fog during part of 
day. Anchor in Gready Island Harbor, 53 miles, at IO.I5 P. M.

July 21.-Start 6 A. M. Anchor IO. IO P. M. in Pottle's Cove, on north side of West Bay, just to the south of the entrance to Hamilton Inlet. Much scattered ice. Distance, 42 miles.

July 22, 23.-At Pottle's Cove. Delayed one day by fog and unfavorable wind, the next by a desire to continue observations here. The sandy beaches in this vicinity are the only ones of any extent in Labrador. Daly discovers glacial strice, the first evidences of glaciation he has found.

July 24--Cross entrance to Hamilton Inlet, making run to Ice Tickle, between Ice Tickle Island and Rodney Mundy Island, 2 I miles, from 6.30 to IO.I5 A. M. Little ice passed, mucl visible ahead. Wind being also against us, further progress through the narrow channels is impossible. Our first display of aurora borealis in the evening. Explore neighboring islands and visit Indian Harbor.

July 25--Contrary winds. Remain at anchor.

July 26.-Make short run of only nine miles, because of shifting of wind to the north. Anchor in Sloop Harbor, between Brig Harbor Island and Sloop Island. Very little ice visible.

July 27.-Light and variable winds. Sail from 5 A. M. to 9.I5 P. M., passing Cape Harrison, and make 5 I miles. Anchor in Jigger Island Tickle. No ice encountered.

July 28.-Fog and unfavorable winds. Run 32 miles from I I A. M. to 9.25 P. M. Little ice. Anchor in an unnamed bight on mainland northwest of Conical Island, and, on account of the experiences of the following day, name it Mosquito Bight. 
July 29.-Light winds. Remain at anchor and get wood. Much trouble from mosquitoes.

July 30.-Almost calm. Drift on to Pomiadluk Point, making only Io miles in the entire day. Climb mountain above the Point, and establish its height as I, I zo feet. Many interesting geological features here-roches moutonnées, conglomerates, lunoid markings, etc.

July 3I.-No wind. Remain at anchor.

August I.-Still calm. Make about three miles in eight hours.

August 2.-Weigh anchor 10.30. Tow out off Pomiadluk Point, and thence, with occasional light winds but mostly calms, make slow and slight progress. At midnight drifting off Cape Mokkovik.

August 3.-Anchor, because of contrary winds, in Summer Cove, Aillik Bay, at 6 A. M. Distance from last anchorage, 14 miles. Adams, Daly, and Delabarre, attempting to land in the surf on a distant part of the shore, are dashed onto hidden reefs and wreck their rowboat. Are later rescued by fishermen who happen by. Boat is recovered and repaired the following day. Small auroral display in the evening.

August 4, 5.-Lack of wind during the morning of the 4 th and probability of its continuance, together with general disinclination of our crew to sail on Sunclays, decide us to remain here two days, explore Mokkovik Bay, and attempt to climb Mt. Altagaiyaivik (otherwise known as Mt. Misery or Monkey Hill, 2, 17o feet). Mokkovik Bay is badly and variously charted, and it was uncertain how far it might extend inland, and whether or not it might interfere with our attempt to reach the mountain. Bigelow, Delabarre, 
and McCornick started on this expedition in the early afternoon of the 4 th; sailed in a small boat four miles to the head of Aillik Bay, and thence walked to the south across an intervening neck to Mokkovik Bay and along the shore of the latter. We passed the night in our sleeping-bags on the shore, after walking a distance of about seven miles. On the following morning we continued along the west shore of Mokkovik to the southward for about seven miles, being then nearly opposite the southern end of Altagaiyaivik, which lay. across the bay on the eastern shore. It was then evident that the bay stretched on for at least four miles further in a southwesterly direction, and that it would be impossible to get around it, climb the mountain, and return to the ship before nightfall. We therefore turned back, returning by nearly the same route as that by which we had come, and reached the ship again at 7.30 P. M. It was evident from our observations that from Cape Mokkovik the bay stretches inland, with several curvings, at least 25 miles. Its general directions are: south, for six or seven miles; southwest, about five miles; south, about six miles; southwest, five miles or more. Near the beginning of the first turn to the southwest is a recently established Moravian Mission station. The bay is surrounded by picturesque hills, of which Altagaiyaivik, 2, I70 feet, is apparently the highest. Its shores in many places are well wooded, the spruce growing to the height of about 50 feet.

August 6.-A fair run of 42 miles, between 5 A. M. and 6.30 P. M., brought us to the Moravian station at Hopedale. We were courteously received by the missionaries, and found our first mail awaiting us.

August 7.-Start at 5.30 A. M. and run 53 miles, anchor- 


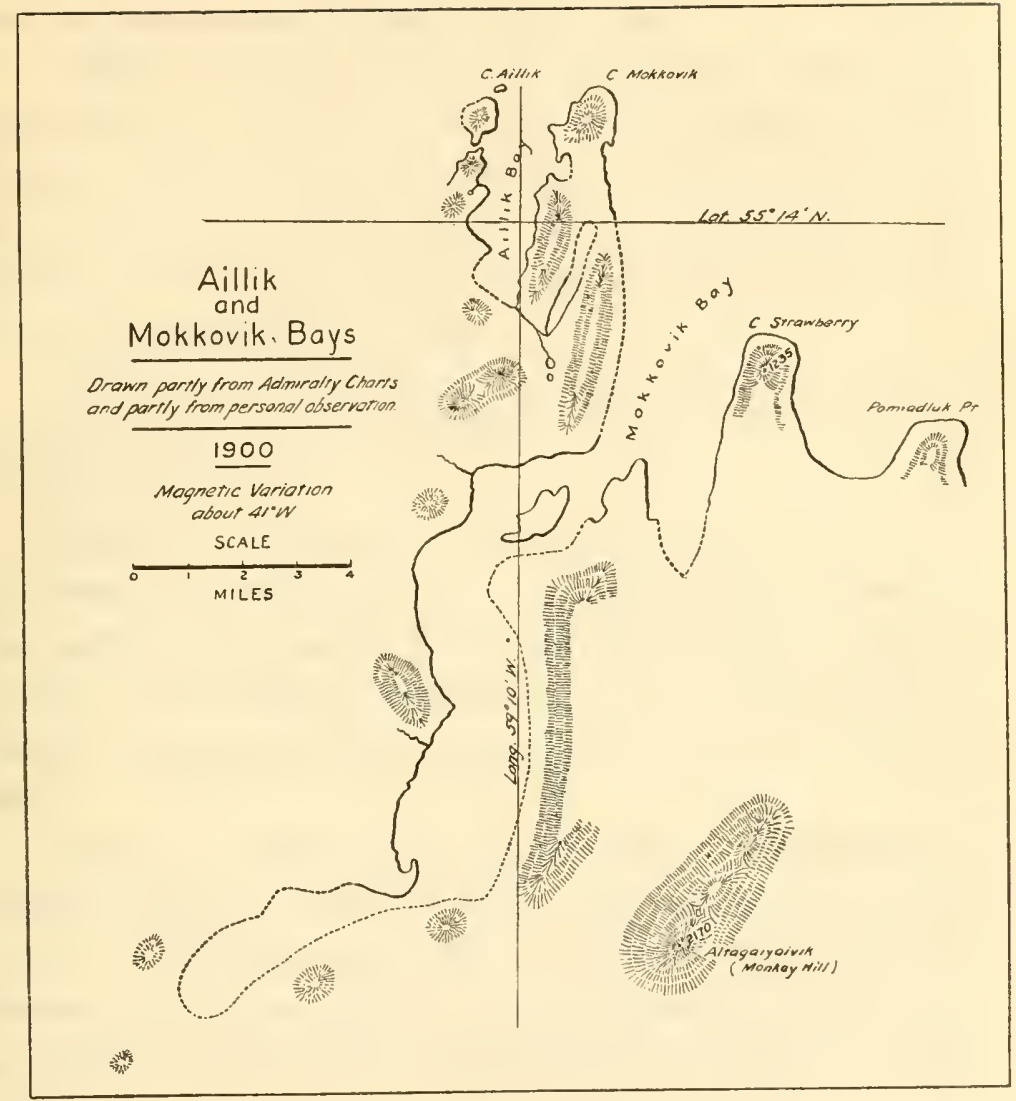

The accompanying chart embodies the results of our observations. Although not based on a careful survey with accurate instruments, but constructed by the cruder methods of visual impressions, compassdirections for the shore-lines traversed, and estimate of distances by the rate of walking, yet it is given as being more accurate than hithertopublished charts. Comparison of this with others, as, for instance, Bryant's map of this section (adapted from Proceedings of the Royal Geographical Society, I888), published with this report, will show how varied and unauthoritative the latter are, and how great is the need of careful work of this sort. Even such a cursory survey as ours could greatly improve the recorded outlines of the islands and coast in hundreds of places; and accurate work by experienced men would be of much value to the numerous vessels that frequent this coast. 


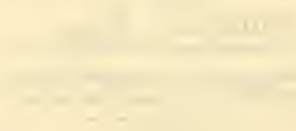


ing at 6 P. м. in Quirk (or Draw Bucket) Tickle, a little to the west of Kikkertaksoak (Spracklings Island).

August 8.-Leave 6.15 A. M. Light winds, becoming almost calm. At 5.I5 P. M. anchor in Ford Harbor, Paul's Island, 26 miles. Mr. Ford informs us that the northern end of the ice-sheet passed here about a week ago. We ourselves have seen no floe-ice since July 28 , and encounter none during remainder of trip.

August 9.-Almost absolute calm. Drift about all day, and make only about three miles. Anchor just outside of Ford Harbor.

August ro.-Start 7 A. M. Calm in morning, light wind in afternoon. Anchor at 8 P. M. at Black Island, 20 miles. Two settlers here, George Webb and Chestry Ford, arrange to take us on hunting expeditions, one on Black Island, known to contain a herd of caribou, and one near Port Manvers.

August is.-Day opens calm and foggy. Bigelow and Palmer start early with Ford to hunt on Black Island. Adams and McCornick set out in skiff with Webb for Port Manvers. Schooner starts II.I5, overtakes and picks up second party, and anchors in Port Manvers, 5.30 P. M., I8 miles.

August 12.-Adams, Delabarre, McCornick, and Webb hunt on mainland. Secure a black bear and a caribou before noon. Other party arrives from Black Island at 9.I 5 P. M., after a wet, cold, and difficult all-day sail in a trap-skiff and a narrow escape from shipwreck.

Angust r3.-Bigelow and McCornick decide to stay in a small hut at Port Manvers until our return from the north. We land supplies, then start I0.45 A. M., sailing 28 miles to Cutthroat Tickle, where anchor at 8.45 P. M. 
August 14.-High northwest wind, diminishing in force. Start II.I 5 A. M. Complete calm after 7 P. M., and tow the ship from 8.30 P. M. to I2.20, when we anchor in bight on south side of Mugford Tickle. Distance made, 28 miles.

August I5.-Absolute calm. Remain at anchor.

August 16, 17.- Start 9.30 A. M. Light wind through Mugford Tickle, calm almost all the rest of the day and the following morning. Northerly gale arises about noon of I 7 th, making it impossible to round Cape Saglek, so we put into Hebron Harbor, anchoring 3.30 P. M.. 45 miles from Mugford. Visit missionaries at the station.

August 18.- Northerly gale continues. Remain at anchor at Hebron. Missionaries tell us of a practicable route overland to Nachvak, about a hundred miles distant. Adams and Delabarre decide to take it, leaving Daly and Palmer to continue in the schooner.

August 19.-Adams and Delabarre start on their overland trip, which is specially described later (in Section III). Ship remains at anchor, with wind light and unfavorable.

August 2O, 2I.-Ship starts I0.30 A. M. Wind light and often failing, and remain out all night. Wind still light the following day, and finally towing is necessary. At 6 P. M. anchor in bight on north shore of Nachvak Bay, three miles west of the narrows, having sailed 76 miles from Hebron.

August 22.-Start 9.45 A. M. and proceed with light winds 15 miles west through Nachvak Bay to Kipsimarvik, where is a station of the Hudson's Bay Company, of which George Ford is agent. Anchor here 4.30 P. M.

August 23 to September 3, inclusive, I2 days, the ship remained at anchor close by Mr. Ford's house, in Nachvak Bay. We were received with great cordiality by Mr. Ford, 
and we owe much to his kindly hospitality during our stay. This was the most northerly point reached by the expedition. Adams and Delabarre arrived August 26th. The time was spent in making as thorough an exploration as possible of the bay and its surroundings. In particular, the bay was sounded and charted, geological and botanical examinations were made of the surrounding country, and measurements of the heights of some of the neighboring mountains. Lowlying clouds, which prevailed during most of our stay, unfortunately made it impossible to accomplish as much of the latter kind of work as we desired. A description is given later (Section IV) of the bay and of the most important ascent made. September Ist was set as the date for our departure, but lack of favorable winds delayed us until the 4th. We would gladly have remained longer in this region, so grand and impressive in its scenery and affording so many opportunities for exploration of value; and we also strongly wished to push on the short distance further to Cape Chidley, and to make a careful study of the interior between it and Nachvak. In fact, this had been one of our strongest desires in undertaking the expedition. But the long time consumed in the outward voyage and the necessity of returning for college work obliged us to turn homeward.

September 4.-Start IO A. M. with light winds, and succeed by 6.30 P. M. in sailing only about four miles. Anchor in a small bight on the west shore of Ivitak (in Nachvak Bay).

September 5, 6.-Start 7.30 A. M. of the 5th. Remain out all night, and anchor in Hebron Harbor, 87 miles, at 2 P. M. of the 6th.

September 7, 8, 9.-Unfavorable winds delay us at Hebron. Snow falls all the afternoon of the 8 th. 
September Io.--Hebron (6 A. M.) to Cutthroat Tickle (5 P. м.), 7 I miles.

September II.-Start 7.30 A. M. At IO A. M. arrive off Port Manvers and attempt to beat in ; but outgoing tide and unfavorable wind prevent. Continue on, therefore, to Black Island, to inquire if $\mathrm{Webb}$ and Ford there have any recent knowledge of the two we left at Manvers. Return later to Port Manvers, anchoring therein at 5 P. M. Bigelow and McCornick rejoin the schooner. Their month here has been pleasant and uneventful. Distance sailed, to-day, 66 miles.

September I2.- Port Manvers (I I.30 A. M.) to John's Harbor, near south end of Aulatsivik (8 P. M.), 30 miles.

September 13.-John's Harbor (7 A. M.) to Nain (5 P. M.), 23 miles. We put into Nain instead of continuing directly southward, for the purpose of visiting a mine of labradorite on Taber's Island, a dozen miles from Nain. At Nain we found Dr. Grenfell, of the Labrador Medical Mission, who kindly offered to take us in his steamer, the "Strathcona," to Taber's Island on the following day. Of Dr. Grenfell and his splendidly conducted mission I shall speak again (Section VI). The generous courtesy he showed us is characteristic of the man, and was a great saving of time to us.

September 14.-Schooner proceeds to Ford Harbor, 20 miles. Members of expedition accompany Dr. Grenfell to Taber's Island, where specimens of labradorite are secured, and rejoin the schooner in the afternoon at Ford Harbor.

September I 5.-Ford Harbor (5 A. M.) to Quirk Tickle ( 5 P. м.), 26 miles.

September I6.-Quirk Tickle (6.30 A. м.) to Hopedale (4 P. м.), 53 miles. Secure our first mail and papers since our previous call here, August 6th. 


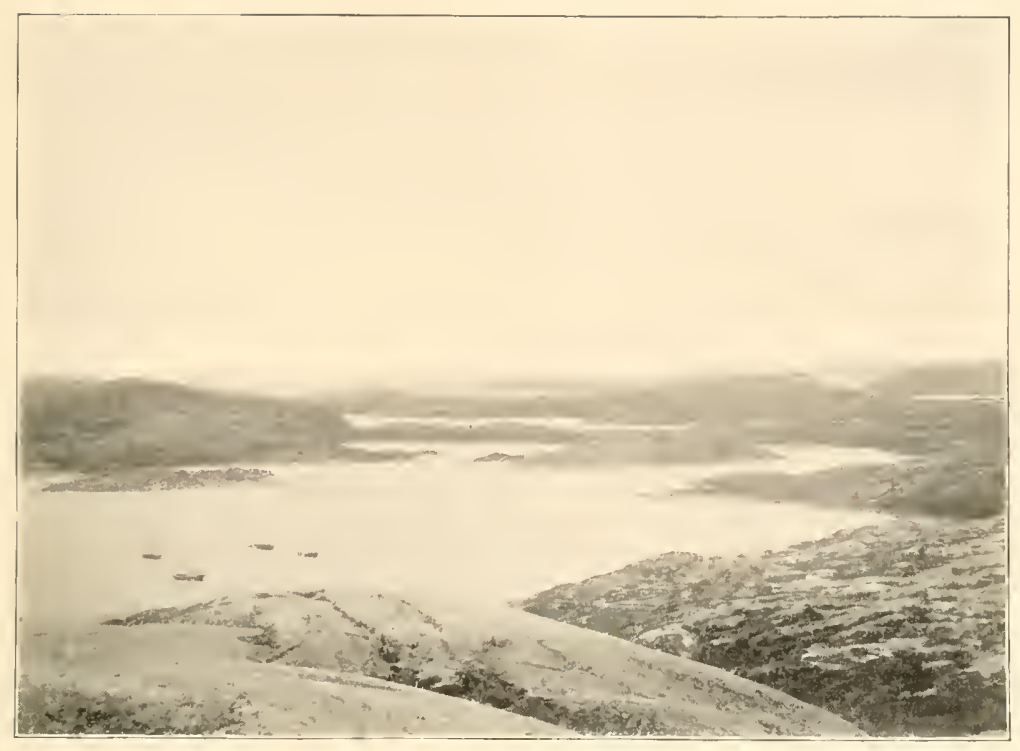

View to the North from a Hill above Hopedale: a typical southern landscape.

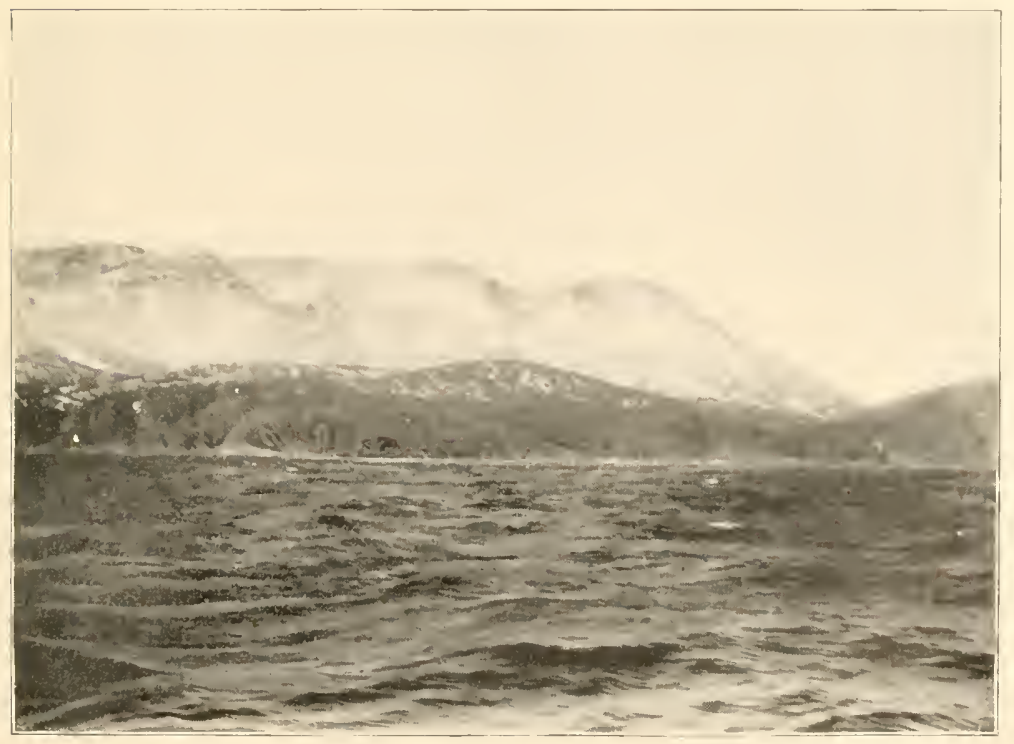

The Kiglapait. 

September 7 7 -Remain at anchor at Hopedale.

September i 8.- Hopedale (6 A. м.) to Sloop Harbor, off Brig Harbor Island (9.45 P. M.), I 25 miles.

September 19.-Sloop Harbor (5.30 A. M.) to Mullin's Cove, on mainland south of Gready Island (7.30 Р. м.), 63 miles. The distance covered during these last two days required i 7 days during the northward voyage.

September 20.-Mullin's Cove (5.45 A. M.) to American Tickle, Seal Islands (3.30 P. M.), 49 miles.

September 2I.-Southerly winds keep us at anchor.

September 22.-American Tickle (5 A. M.) to Cape St. Francis Harbor (4 P. M.), 42 miles.

September 23. 24.-Detained by unfavorable winds.

September 25, 26.-Leave Cape St. Francis 6 A. M. Cross the Straits of Belle 1sle. Wind drops in afternoon, and we beat along off Cape Bauld and White Islands all night. Fresh wind from the south causes us to anchor at Grand Brehat, Newfoundland, at 7.30 A. M. of the 26th. Distance, 78 miles.

September 27.-At anchor.

September 28.-Leave Grand Brehat 7 A. M. At noon, on account of thick, foggy weather and other unfavorable conditions, anchor in harbor of Cape Rouge (or Crouse), 40 miles.

September 29, 30.-Detained by unfavorable winds.

October I, 2.-Start 2 A. M. and take six hours to get out of the harbor. A favorable wind is met outside, and we cover the 268 miles to St. John's in 40 hours. Are well within the harbor by midnight of the $2 \mathrm{~d}$, and come to anchor there a half hour later.

It was with great surprise that we learned, soon after our 
arrival, of the undue prominence that had been given to our expedition in the newspapers. They had taken advantage of our lateness in returning, and of a hurricane that had recently wrought much havoc on the Newfoundland coast, to proclaim that we were probably lost. There was no foundation whatever for their sensational accounts. We had not encountered the hurricane, nor otherwise been in peril.

The voyage on the whole was one of great pleasure and profit. The wild, mountainous scenery of the coast alone would have repaid us. The slowness of our progress made impossible of accomplishment some of our original projects; but it really interfered with very few of them, and, on the other hand, it helped far more than it hindered. To it is due the fact that we examined the coast in a more thorough and detailed manner than had previously been accomplished, and thus made a considerable number of observations and discoveries of scientific interest, particularly along geological lines. The results of our work will be given in Section VII and following.

\section{II}

SUMMARY OF THE VOYAGE, AND METEOROLOGICAL CONDITIONS.

A considerable portion of the data about to be given is derived from observations of such a nature that there can be no question as to their accuracy. But others depend upon the records of more or less faulty apparatus, and the tables summarizing these records cannot lay claim to any high degree of value. They may serve to give a fairly good general idea of the conditions under which the trip was made; 
but they cannot be used as a basis for calculations or deductions where a close approximation to absolute accuracy is essential. None of the members of the expedition had had previous experience in the taking of meteorological records; there was no opportunity before the start to visit Washington for the purpose of obtaining reliable instruments and instruction in their use; and the time of the members during the trip was so often devoted to other scientific interests that there was a considerable amount of irregularity in making these observations. Records were kept, however, with such regularity as was possible, in spite of the imperfection of the instruments, mainly for the satisfaction of the members of the party. Realizing that they contain a high and indeterminable degree of error, I have had some doubt as to the expediency of publishing them. It has been suggested, however, that they may not be absolutely without value, and so they are given out with these words of caution as to their reliability.

The expedition left St. John's in the "Brave" on the afternoon of June 25th, and re-arrived at St. John's just after midnight of the morning of October $3 \mathrm{~d}$. The voyage was thus finished on the Iooth day after the departure. On the northward journey, I 8 days were passed in Newfoundland; 4I days, from July I $3^{\text {th }}$ to August 22d, in going along the Labrador from the Straits of Belle Isle to Nachvak Bay. On the return, 22 days, from September 4th to September 25 th, were passed on the Labrador, and seven days on the Newfoundland coast. It thus took 59 days to make the northward journey; 12 days were devoted to the stay at Nachvak; and 29 days were required for the return. The southward trip was accomplished in about half the time of the north- 
ward. During one day of the return (September I8th), a distance was covered that had occupied, on account of unfavorable winds alone, I d days in going north; and on the following day a distance to which six days had previously been devoted. The other gains were smaller.

The total distance sailed was about 2, IOO miles, of which not far from I, 400 were along the Labrador coast in the two directions. The rate of travel, counting only the days on which some progress was made, averaged $33 \frac{1}{2}$ miles a day on the way north, 55 miles on the way south, and about 42 miles for both together.

It was possible to sail at all on only about half the days devoted to the voyage: and very nearly the same proportion held for both the outward and the return voyage. Of the days during which some progress was made, from one-third to one-half were so unfavorable that a distance of less than 25 miles was covered. Thus, on the journey north, of the 59 days, only 3 I permitted any sailing at all (and two of these were without any real advance), only 25 saw a greater distance covered than 15 miles, and only 22 more than 25 miles. On the return, during I9 days of the 29 , some distance was made, during 16 more than 15 miles, during only i 4 more than 25 miles. Going north (59 days), detention was due: to ice-floes, 9 days (the ice proving a serious obstacle to progress on several other days also), to unfavorable winds, I7 days, and to voluntary delay, 2 days. On 6 other days a distance of less than 15 miles was covered. This makes a total, not including the two days of voluntary detention, of 32 unfavorable days (more than half) on which it was impossible to progress at least I 5 miles. Going south (32 days, counting 3 at Nachvak, on which it had been planned to sail), 
unfavorable winds prevented sailing on I 3 days and prevented progress of at least 15 miles on 3 additional days-a total of 16 unfavorable days, or exactly one-half.

The two chief obstacles to progress were thus the large floes of ice streaming southward along the coast, and winds contrary in direction or insufficient in force. The last trouble from the ice was on July 24, at Ice Tickle; the last day on which we saw any floe-ice at all was July 28 ; and Ford, of Paul's Island, said that the northern end of the ice-sheet passed Ford Harbor about the ist of August. The prevailing winds were from the northerly and southerly quarters. During the northward voyage, nearly half the winds (44 per cent.) were northerly, and only 25 per cent. southerly. During the return, about 30 per cent. were from the north and 3 I per cent. from the south.

According to the Newfoundland and Labrador Pilot, "gales are stated to be frequent and violent" on the Labrador coast. The expedition encountered but one or two of any considerable force, during which it was safely in harbor. The Pilot further says that calms are of short duration, "rarely lasting more than one day." About I4 per cent. of the observations taken during the entire trip recorded no wind at all. If we group among the calm days those on which less than 5 miles could be sailed, as well as those when the wind was insufficient to permit any sailing at all, then 25 per cent. of all the days during the northerly voyage were calm, and there were many more when it was calm during a portion of the day. About the same proportion held for the voyage southward. These calm days came quite as frequently several in succession as singly.

The following table gives in their order from St. John's northward the different harbors at which we touched, the 
date of our arrival (except St. John's outward and Hudson's Bay Post, Nachvak, homeward, when it is the date of the departure), and the approximate distances from the last previous station (to be read downward for the outward and upward for the homeward trip) :-

TABLE I.

LOCATION OF THE "BRAVE" THROUGHOUT THE VOYAGE.

\begin{tabular}{|c|c|c|c|c|c|c|c|c|c|}
\hline & \multicolumn{4}{|l|}{ STATIONS * } & $\begin{array}{l}\text { OUT- } \\
\text { WARD }\end{array}$ & \multirow{2}{*}{$\begin{array}{c}\text { DIS- } \\
\text { TANCE } \\
\\
.\end{array}$} & \multicolumn{2}{|c|}{$\begin{array}{l}\text { HOME- } \\
\text { WARD }\end{array}$} & \multirow{2}{*}{$\begin{array}{c}\text { DIS- } \\
\text { TANCE } \\
268\end{array}$} \\
\hline I & St. John's, N. F., . . . . & & & & June 25 & & Oct. & 2 & \\
\hline 2 & Greenspond Island, N. F., . . . & & . & & June 26 & 109 & . . & & \\
\hline 3 & Change Island, N. F., . . . . . & & . & & July 2 & 60 & & & \\
\hline 4 & Cape Rouge, N. F., . . . . . . & & . & & $\therefore$ & & Sept. 2 & & 40 \\
\hline 5 & Grand Brehat, N. F., . . . . & & . & & & . . & Sept. 2 & & 78 \\
\hline 6 & Kirpon Harbor, N. F., . . . . & & . & & July & 150 & 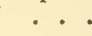 & & . \\
\hline 7 & Hare Island, Lab., . . . . . . & & - . & & July I 3 & 43 & . . & & \\
\hline 8 & Assizes Harbor, . & & . . & & July 14 & $\cdot$. & . $\cdot$ & & \\
\hline 9 & Cape St. Francis Harbor, . . . . & & . & & . . . & . . & Sept. & & 42 \\
\hline 10 & American Tickle, . . . . . . . & . & . . & & .. & & Sept. 2 & 20 & 49 \\
\hline I I & Seal Island, . . . . . . . . . & & . $\cdot$ & & July $\mathbf{I 7}$ & 65 & . . & . & . \\
\hline 12 & Mullin's Cove, . . . . . . . . & & - . & & & & Sept. & 19 & 63 \\
\hline 13 & Gready Island, : . . . . . & & . & & July 20 & 53 & . & . & \\
\hline 14 & Pottle's Cove, West Bay, & & . & & July 2 I & 42 & . - & . & \\
\hline 15 & Ice Tickle, & & - . & & July 24 & 21 & . $\cdot$ & & - $\cdot$ \\
\hline 16 & Sloop Harbor, Brig Harbor Island & & - & & July 26 & 9 & Sept. & 18 & 125 \\
\hline 17 & Jigger Island, & & $\cdot \cdot$ & & July 27 & $5 I$ & . & & \\
\hline 18 & $\begin{array}{l}\text { Mosquito Bight (unnamed on cliart } \\
\text { of Adlavik Islands), . . . . . }\end{array}$ & & wes & & July 28 & $3^{2}$ & & & \\
\hline 19 & Pomiadluk Point, . . . . . . . & & . & & July 30 & 14 & . . & . & \\
\hline 20 & Aillik Bay, . . . . . . . . . . & & . & & Aug. 3 & I4 & . $\cdot$ & & . . \\
\hline 21 & Hopedale, . . . . . & & - . & & Aug. 6 & 42 & Sept. & 16 & 53 \\
\hline 22 & Quirk (or Draw Bucket) Tickle, & & - . & & Aug. 7 & 53 & Sept. & I 5 & 26 \\
\hline 23 & Ford Harbor, . . . . . . . . . & & • & & Aug. 8 & 26 & Sept. & I4 & 20 \\
\hline 24 & Ford Run, . . . . & & - $\cdot$ & & Aug. 9 & 3 & $\cdot$ & . & . . \\
\hline 25 & Nain, . . . . . . . . . . . & & . & & . $\cdot$ & . . & Sept. & I3 & 23 \\
\hline 26 & John's Harbor, . . . . . . . & & - & & . . . & . $\cdot$ & Sept. & 12 & 30 \\
\hline 27 & Black Island Harbor, . & & . & & Aug. Io & 23 & (Sept. & I I) & \\
\hline 28 & Port Manvers, . . . . & & & & Aug. I I & I8 & Sept. & II & 28 \\
\hline 29 & Cutthroat Tickle, & & & & Aug. 13 & 28 & Sept. & Io & 71 \\
\hline 30 & Mugford Tickle, . . . & & & & Aug. 14 & 28 &. & & \\
\hline $3 \mathrm{I}$ & Hebron, . . . . & & - & & Aug. 17 & 45 & Sept. & & 87 \\
\hline 32 & Skynner's Cove, Nachvak Bay, & & & & Aug. 21 & 76 & - & • & \\
\hline 33 & Ivitak, Nachvak Bay, . . - . & & & & . . & . . & Sept. & 4 & 4 \\
\hline 34 & $\begin{array}{c}\text { Hudson's Bay Post (Kipsimarvik), } \\
\text { vak Bay, . . . . . . . . }\end{array}$ & & Nach & & Aug. 22 & 15 & Sept. & 4 & \\
\hline
\end{tabular}

* The authoritative spelling of some of these names is doubtiul. Different charts do not always agree with one another, nor with the Ncrefoundland and Labrador Pilot. 
Sun, Rain, and Snow'-There was a fairly even proportion of sun and rain. About one-fourth of the days were wholly sunny; only about one-third of them were without any sunshine at all. Very nearly half of the days had some rain, though of these only 6 were rainy ail day. The amount of rain that fell was not large. Usually there occurred only light showers or drizzle, and there was not a single really heavy rainfall. Snow fell only once at sea-level, on September 8 th. There were no thunder showers, though once or twice single faint claps of thunder were heard, no lightning being visible. The first half of the trip was more rainy than the rest of it. Of the 49 days to August I2th, only I 5 were without rain, and 3 of these were overcast. The longest periods without rain were 9 days from August I 3 th to August 2Ist, 3 of which were overcast; and 7 days from September 9 th to September I 5 th, none of them wholly overcast. The longest period of overcast skies consisted of Io successive days, from August 28th to September 6th, on 4 of which there was rain, and on 2 a very small amount of sun.

These observations compare with others accessible to us as follows: The Pilot speaks of "the few fine days of summer." Low (Explorations in the Labrador Peninsula, I886, p. 29), remarks: "During the summer season the precipitation, if not great, is constant, as a day rarely passes without drizzle, or thunder showers, which lower the temperature." Yet Bryant (Journey to the Grand Falls of Labrador) speaks of only IO of the 4I days from August 4 to September I3, I89I, as rainy, 3 as having occasional showers, and one as cloudythe remaining 27 being presumably largely sunny. During the same period as Bryant, we, on the coast to the north of Hamilton Inlet, had 5 days with more or less rain, though of these 6 had a large proportion of sunshine; and there were 
Io others that were wholly or predominantly cloudy. Low's observations were made in a part of the country for the most part very different from that of our own expedition. In r893, between August I 3th and September 3oth, his journeyings corresponded most nearly with our own, covering the territory from the Upper Koksoak to Chimo, around to the Atlantic coast, and south to Rigolet; and of the 48 days, 5 had rain and about 20 others were overcast (clouds 7 or more on a scale of IO). In I $\$ 94$, between July Ist and August 24th, he was on the Upper Hamilton, among the lakes, and on the Romaine River south to Mingan; of the 55 dlays, there was rain on 36 and 7 were overcast. In 1895 , July rst to September 2d, in the vicinity of the Manicouagan River, of the 64 days, 46 were rainy. All authorities agree as to the small amount of annual precipitation.

These comparisons are summarized in the following table. In considering the comparisons, one must remember that the observations of Low and Bryant were made for the most part in the interior, in the localities above mentioned, while ours were made on the coast; and that some error may arise from my interpretation of their records, the terms used by them not being identical with those given here:-

TABLE II.

SUNNY, OVERCAST, AND RAINY DAYS.

\begin{tabular}{|c|c|c|c|c|c|}
\hline & \multirow{2}{*}{$\begin{array}{l}\text { BRYANT. } \\
\text { Aug. 4- } \\
\text { Sept. I3, } \\
\text { r891. }\end{array}$} & \multicolumn{3}{|c|}{ Low. } & \multirow{2}{*}{$\begin{array}{l}\text { "Brave." } \\
\text { June 25- } \\
\text { Oct. 2," } \\
\text { 1900. }\end{array}$} \\
\hline & & \begin{tabular}{|} 
Aug.13- \\
Sept. 30, \\
1893.
\end{tabular} & $\begin{array}{c}\text { July I- } \\
\text { Aug. 24, } \\
\text { 1894- }\end{array}$ & $\begin{array}{c}\text { July } x- \\
\text { Sept. 2. } \\
\text { 1895. }\end{array}$ & \\
\hline $\begin{array}{l}\text { Days wholly or largely sunny, } \\
\text { Days largely overcast, without rain, } \\
\text { Days mainly sunny, with some rain, } \\
\text { Days mainly overcast, with some rain, } \\
\text { Days predominantly rainy, }\end{array}$ & \} $\begin{array}{r}27 \\
1 \\
3 \\
10\end{array}$ & $\begin{array}{l}23 \\
20 \\
. \\
5\end{array}$ & $\begin{array}{r}12 \\
7 \\
36\end{array}$ & $\begin{array}{l}18 \\
: \\
46\end{array}$ & $\begin{array}{r}30 \\
19 \\
16 \\
28 \\
7\end{array}$ \\
\hline Total days, . . . . . . & $4 I$ & $4^{8}$ & 55 & 64 & 100 \\
\hline
\end{tabular}


Our own observations can be presented best in another series of tables, as follows:-

TABLE III.

SUNSHINE AND RAIN.

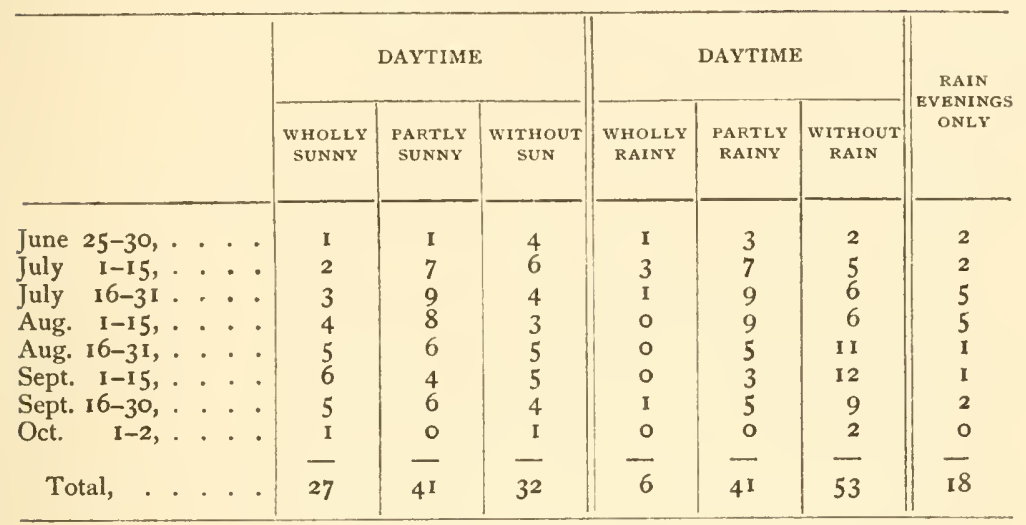

TABLE IV.

FREQUENCY OF CLOUDS.

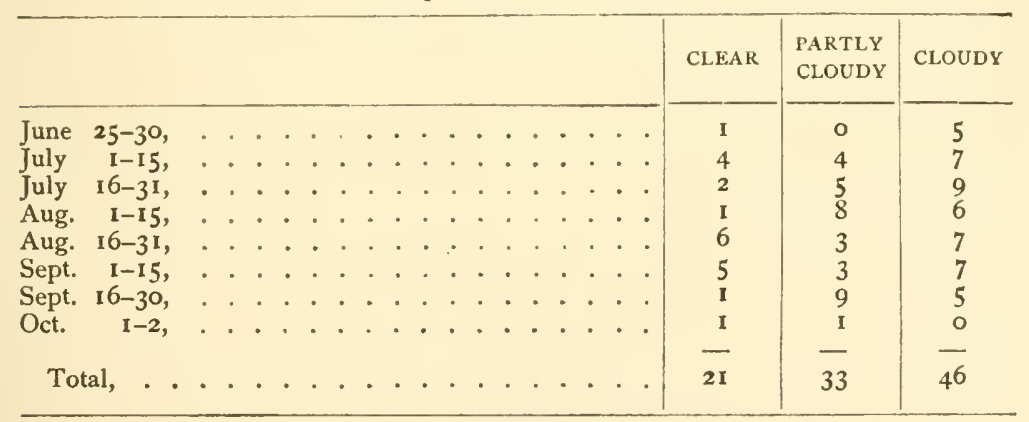

TABLE V.

NUMBER OF FOGGY DAYS (LABRADOR ONLY).

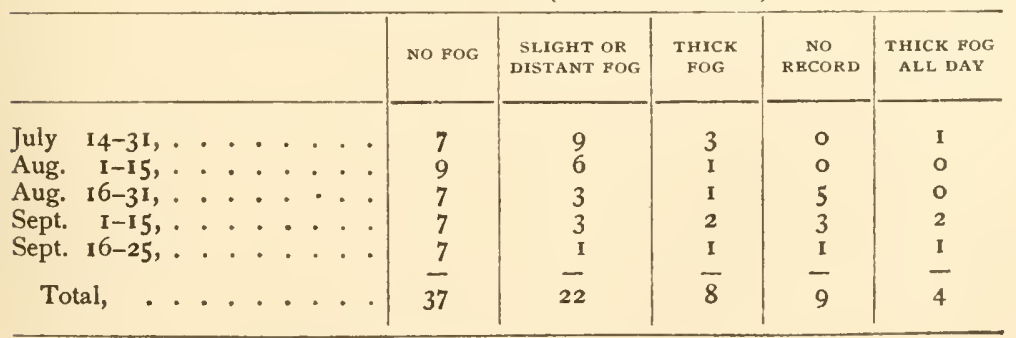

Total days, less repetitions of Column 5, 67 . 
Temperature.-In spite of the cold Arctic current that sweeps southward along these shores, the summer was, on the whole, very comfortable and fairly uniform in temperature. The observations made by the expedition suffered considerably in accuracy from the fact that the thermometers used were not wholly reliable, and from the impossibility of finding on the ship any situation where the instruments could be wholly shaded from the sun and have free circulation of air about them. To some extent the observations could be corrected by the aid of other observations made at irregular intervals for other purposes by Dr. Daly, using a thoroughly reliable thermometer. The results thus attained, while not entirely accurate, are yet of some value in judging the summer temperature of the Labrador coast. The highest temperature recorded by the instruments was $78^{\circ}$; the probably highest actual (corrected) temperature was $72^{\circ}$. The lowest temperature was $30.5^{\circ}$. The average was $46^{\circ}$. There were only five days recorded, and probably only one actually, when the maximum exceeded $70^{\circ}$. On about 33 days, or one-third of all, the maximum was less than $50^{\circ}$. On only 6 days was the minimum below $32^{\circ}$, but on 45 days it was below $40^{\circ}$. The average daily range of temperature was $13^{\circ}$, the highest range $25.5^{\circ}$, the lowest $4.5^{\circ}$.

Of the temperature in the interior, north of Lake Mistassini, Low says that $80^{\circ}$ is exceeded on only a few days during the summer season; that $45^{\circ}$ below zero appears to be the minimum winter temperature of most years; and that the mean temperature at the lake in 1885 was: for June 53..$^{\circ}$, for July $59.9^{\circ}$ (ours was $46.2^{\circ}$ ), and for August $56.7^{\circ}$ (ours $49.4^{\circ}$ ). Bryant found the minimum temperature for his journey $29^{\circ}$, the maximum $82^{\circ}$, the mean minimum $42^{\circ}$ 
(ours for about the same period was about $4 \mathrm{r}^{\circ}$ ), and the mean maximum $5^{\circ}$ (ours $57^{\circ}$ ). Wakeham (Report of Expedition in Steamship "Diana" in 1897), from June 27 to October 9, I897, found a maximum temperature of $79^{\circ}$, a minimum of $27^{\circ}$, and a mean of $43 \cdot \mathrm{I}^{\circ}$. According to the Pilot, the mean temperature in 1875 for the coast between Cape Porcupine and Nain was : in July $46.5^{\circ}$ (ours $46.2^{\circ}$ ), in August $50.3^{\circ}$ (ours $49.4^{\circ}$ ), in September $44.5^{\circ}$ (ours $43.1^{\circ}$ ).

Our daily temperature-readings are not possessed of a sufficiently assured and complete accuracy to make it desirable to give them in full. Grouped together by half-months, the records, corrected so that they are fairly reliable, yield the results seen in the following table. The maxima and minima were given by a recording themometer, a modification of Sixe's type (similar to the Miller-Casella instruments). The daily range of temperature was obtained from this instrument by determining the difference between its recorded maximum for the day and minimum for the night. Average (I) was obtained by determining the daily mean of the maximum-minimum records. Average (2) was calculated from three daily readings at stated hours. The corrections were made by comparison of the records of the regularly used thermometers with those occasionally taken with great care by aid of a fully-tested and corrected centigrade thermometer loaned to Dr. Daly by the United States Coast and Geodetic Survey, which, unfortunately, had to be used most of the time for other purposes, and hence was not available for these daily observations.

Comparison of our averaged results with those of other expeditions, as quoted above, seems to indicate that our degree of error was not so large as to destroy altogether the value of the table here given. 
TABLE VI.

TEMPERATURE.

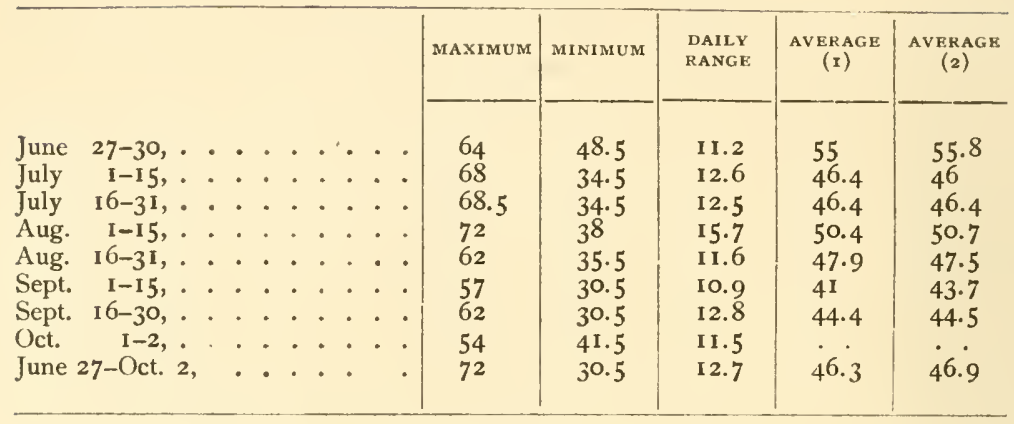

Relative Humidity.-The hygrometer at our disposal for the measurement of the relative humidity of the air was very imperfect, and its findings are uncertain as to their value. Its readings, however, corrected by later comparison of our hygrometer with another reliable instrument, furnish the following conclusions, which can be regarded as having only a relative value: The maximum humidity was 100 , the minimum 27.5, the mean 82. July was most moist, with a mean of 93. August was dryest, with 76 . September had a humidity of about 8 o. Of our 245 observations, only 37 were as low as 65 , and of these only eight were as low as 50 , and only two 40 or under; I 62 were 80 or more; i 27 were 90 or more.

Pressure.-The barometric pressure ranged from 29.28 to 30.75 , with a mean of 29.82 . Wakeham, in 1897 , between June 27 and October 9, experienced a range from 29.3I to 30.37 , with a mean of 29.82 . On only three occasions up to September 22 did the barometer rise above 30.20 , one of these occasions covering three days. From September 22 on, it was above 30.20 almost constantly, dropping below it 
for two short periods only. On six occasions, two of them covering three days each, it fell below 29.50.

The records from June 27 to July I5, inclusive, are from the ship's aneroid, which was neither compensated nor tested, and which reads from I-IO to 3-Io lower than the other. The records for these dates are therefore inclosed in parentheses in the table. Records after July I 5 are from a far more reliable compensated aneroid (Thaxter, Boston), reading to 5,000 feet. The latter was compared under widely varying pressures with the standard mercurial at Cambridge, Mass., from which it was found to vary but very slightly. It was also subjected to frequent tests by Dr. Daly during the trip, by means of comparisons with measured heights and with other barometers, and found to possess a high degree of accuracy.

TABLE VII. PRESSURE.

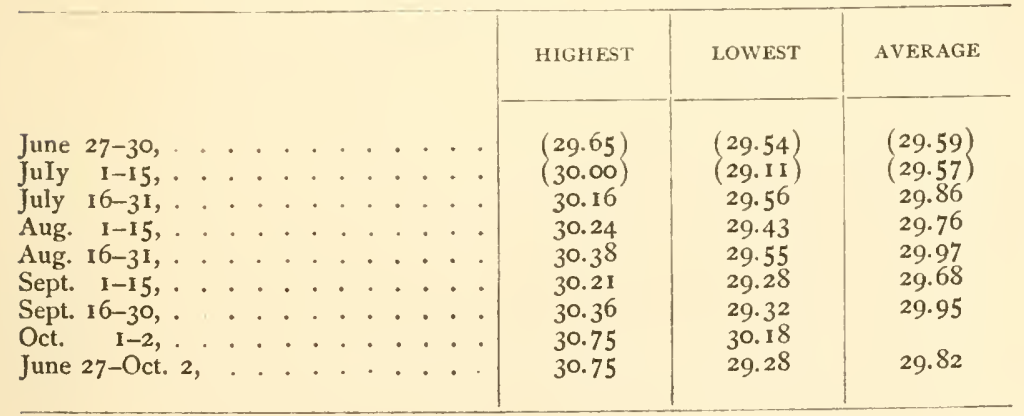

III.

OVERLAND FROM HEBRON TO NACHVAK.

Hebron Harbor is situated near the entrance to Kangerdluksoak, a narrow bay extending many miles to the westward into the interior of Labrador at about latitude $58^{\circ}$ 
north. About a hundred miles north of it is Nachvak Bay, also long and narrow. Between them the coast is much indented, containing a host of small bays, and also two of larger size-Saglek* and Nullatartok. At the entrance to the latter is situated Ramah, the most northerly of the Moravian Missions in Labrador: The intervening country is traversed never, probably, by white men, unless a portion of it in the winter by dog-sledge, $\uparrow$ but not infrequently by Eskimos, who have regular routes across it. Transportation across the bays is easy to secure because of a summer fishing settlement of Eskimos on the shore of Saglek, of the mission station at Ramah, and of the Hudson's Bay Company's post at Nachvak.

These facts we learned from Mr. Townley, one of the missionaries at Hebron. Adams and the writer, eager to do some interior exploration, decided to make this trip, leaving the schooner to go on when it could to Nachvak. We secured as guide Amandus, a young Eskimo, who knew the way as far as Ramah. For his services we were to pay fifty cents a day and provide him with food, tobacco, and transportation in the schooner back to Hebron.

The morning of Sunday, August 19, was devoted to preparations for departure. Of provisions we took enough for a week, consisting chiefly of compressed emergency ration and ship's biscuit. Our further equipment included

* More commonly spelled Saeglek.

$\dagger$ The dog-sledges for the most part travel on the ice along the coast. One white man, named Colley, is said to have walked, a number of years ago, along the entire coast from far south through Hebron to Nachvak, and thence across to George River. Nothing is known of his antecedents or real purpose; he claimed to be in search of a brother. $\mathrm{He}$ was probably mentally unsound, and at George River he committed suicide. 
sleeping bags, camera, aneroid barometer, thermometer, and rifles. At 2 P. M., local time (forty minutes behind St. John's time), we set out from the schooner. Our first ten miles were made in a trap-skiff, westward through Kangerdluksoak Bay, in order to get to the rear of Mt. Johannes, which rose in our way a little back of the mission house. Our crew, consisting of Amandus, his brother, and two small Eskimo boys about ten years old, were very merry, continually laughing, joking, and singing, and showing themselves sturdy. and willing workers. We found these excellent qualities in Amandus throughout the trip. All about the bay rose mountains, a few of them precipitously from the water's edge. Those near the bay attain a height apparently of about 2,500 feet. Most of them are rounded and glacier-worn, with numerous projecting and impressive knobs. Far off to the south a snowy peak was sometimes visible over the nearer heights, and to the west were other still higher summits.

At six o'clock we landed just beyond the furthest ontlying slopes of Johannes. From this point a low, wide valley, rising in the middle not more than 50 feet, stretched northward two and a half miles to a small bay called Iterungnek. Shouldering our packs, we walked through this valley. Back of us the sunset was lighting up the hills, the nearer ones with yellow, the more distant with violet hues. We soon passed what our guide said were Eskimo houses-rude walls of stone built under a projecting rock and forming two rough shelters. They looked black and old, but their sombre hues were relieved by pink masses of fireweed flowers growing thickly about them. Further on, on the shore of the bay, was a group of ancient Eskimo graves. We rounded the head of the bay, skirted the shore for a little distance further, and at 
7.35 made our camp for the night, about four miles from our starting point, near a small brook of clear, cold water. The dead branches of two-foot willows furnished us with firewood, and Amandus soon had our pots boiling over a very diminutive fireplace. As we crept into our sleeping-bags, after writing up our notes by the dim firelight, the sky was brightly illuminated by a fine display of northern lights, centered chiefly in the magnetic south.

The night was chilly. At 4.20 , when we arose, the temperature was $47^{\circ}$, and it rapidly became warmer. We had a flood of bright sunshine all day long. Our route was up and down hill all the way. The highest point was attained toward noon, at I,560 feet. From this elevation we caught a glimpse of a group of bold mountains to the north, across Saglek Bay, some of them apparently of the so-called "houseroof" formation. When we stopped for lunch a little later, the temperature was $63^{\circ}$. In the early afternoon we continued for several miles at a general elevation varying from I,O5O to I, I 60 feet, and then made a steep descent to a river flowing northeastwardly into Kajuktok, a portion of Saglek Bay. A line of hills, I, 300 feet in height, then lay before us, between the river and the bay. We had but just forded the river and begun their ascent, when we were fortunate enough to shoot a doe. Amandus concealed the carcass, intending to return for it after he reached home again; and we took with us a leg, which added greatly to our larder during the rest of the trip. Then we continued up the hill, walked on for a couple of miles along its nearly level summit, and at seven o'clock stopped for the night near its final crest. We had walked during the day about 16 miles. Mosquitoes were thick, and prevented sleep for some time. A wonderful 



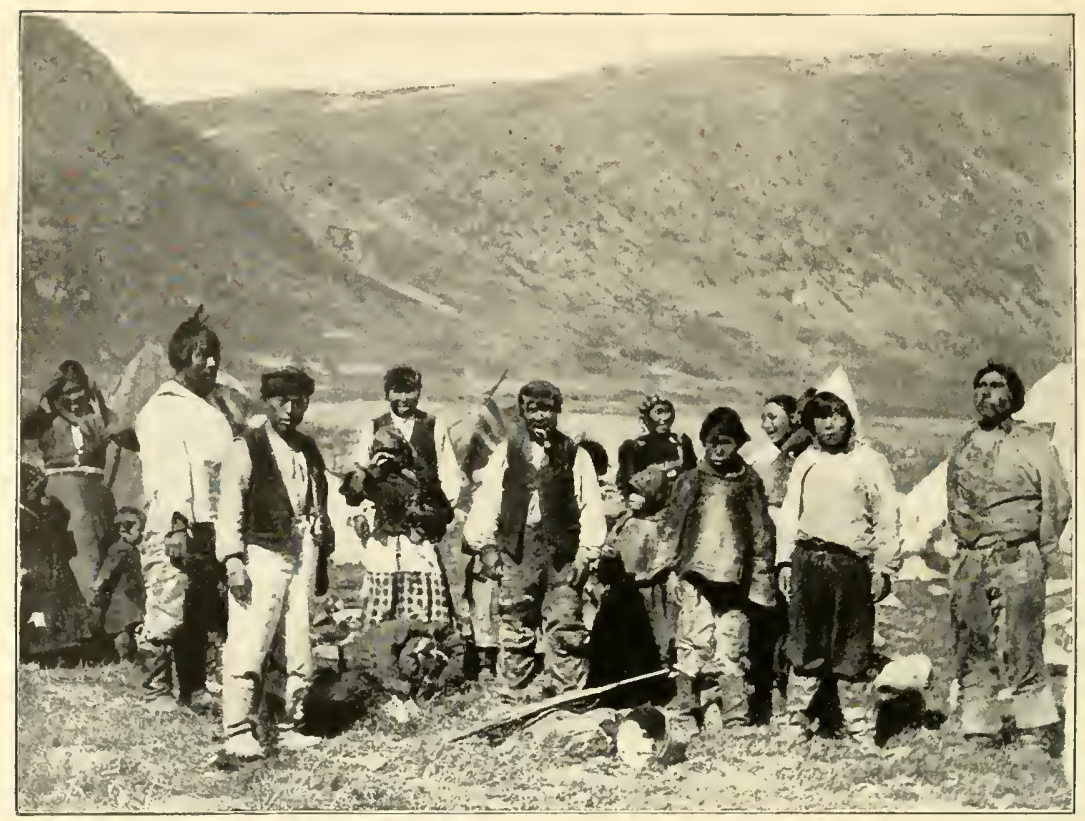

Eskimo Encampment at Pangnertok.

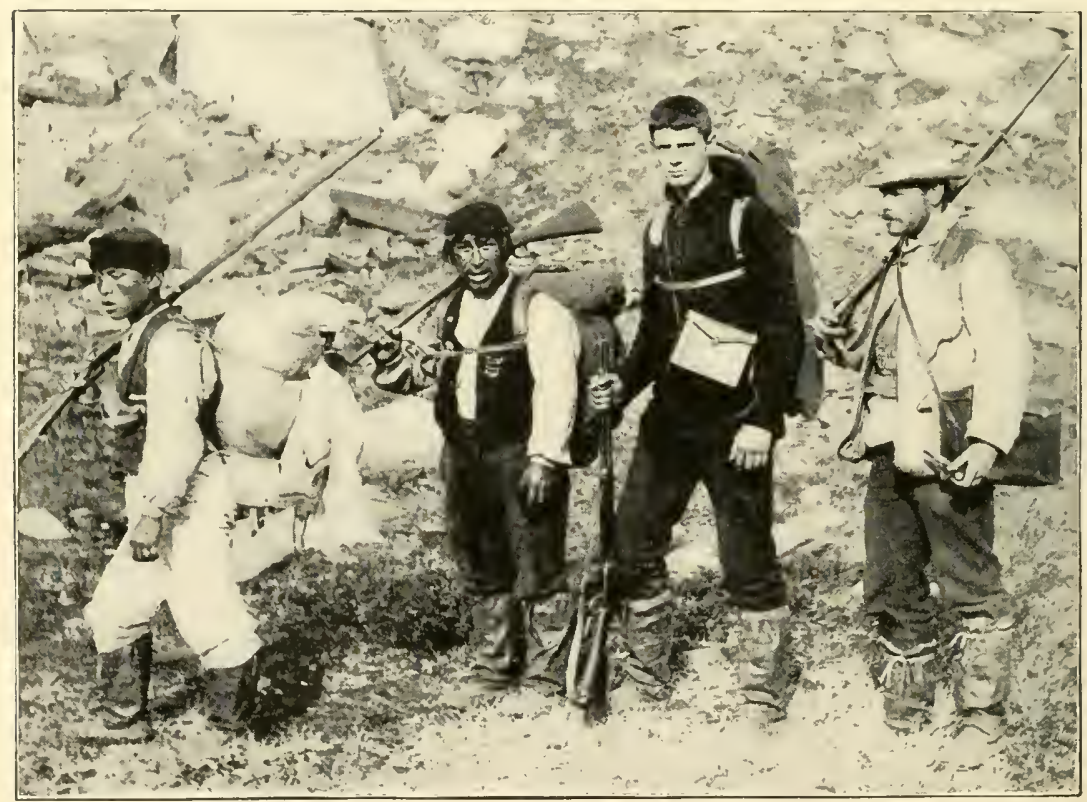

Members of the Party on the Overland Trip from Hebron to Nachvak. 
auroral display was some compensation for our wakefulness. Its mild light swept over the heavens, for the most part taking the form of curved vertical bands, changing and wavering.

Our third day, August 2Ist, was another one of bright, warm sunshine. At 8.30 , just before our start, the temperature was $63^{\circ}$. From the crest of the hill, which we soon reached, we had a beautiful view toward Saglek Bay. Just below us was a wide, level stretch, reaching from the foot of our slope to Pangnertok, a branch of Saglek. To our right a brook tumbled down, and to the left a considerable river emptied into the head of Pangnertok. Beyond lay the waters of the bay, from whose further shore rose up the rooflike mountains we had first seen the previous day, with their almost vertical sides seamed with gullies and bare of vegetation. On the flat near the mouth of the river was an Eskimo encampment. We hastened down and reached it at ten o'clock. The little settlement consisted of two canvas tents and two skin topeks. The fishermen who live in them are Hebron Eskimos, spending the summer here for the sake of the trout in the nearby streams. They welcomed us with much hospitality, invited us into their tents, and otherwise showed their interest and good-will. It was nearly 2.30 before the tide had risen sufficiently to allow their trap-skiff to get out of the river into the bay. Then we set out and had a delightful sail, down Pangnertok under the steep face of Mt. Pinguksoak on the further shore, past Kajuktok, the bay into which empties the river crossed yesterday, into the main bay, and across it past the islands of Aulatsivik and Saglek to the northern shore. The scenery of the bay was strikingly beautiful, far surpassing in its wild grandeur any that we had seen. The mountains were everywhere 
crowded down close to the water, from which most of them rose up precipitously except for a short talus at the bottom; and similar steep cuts extended up into the tributary valleys. The heights varied probably from 3,500 to 5,000 feet. We sailed and rowed for four hours through this gorgeous scenery, under a sky entirely clear except for a few high, fleecy clouds. Our Eskimo crew were friendly and interesting. At the end they demanded but one plug of tobacco apiece for their services. We landed at 6.30, and were soon again on the march. We had not proceeded far, however, before we sighted two caribou, a doe and a fawn. We dropped our packs and went in pursuit; but darkness intervened before we could overtake them, and so they happily escaped. A hard walk through soft bog and over rough talus brought us back to our packs, where we camped for the night. The auroral display was the finest we had seen. It covered almost the entire sky and gave a light almost as brilliant as moonlight. There was a great variety in the patterns it formed, with an uneasy, restless play and quivering of the bands, as though a light wind were blowing with enormous rapidity through a bright, thin mist.

On Wednesday, the $22 \mathrm{~d}$, we arose at five o'clock. A thin, chill fog was in the air, and after a little it began to sprinkle. At 6.20 the temperature was $45^{\circ}$. At 6.30 we were started on our fourth day's journey. The valley that lay before us, running up into the mountains northward from Saglek Bay, was wide and level for the first two miles, formed of alluvial deposits, and then ascended gradually in a narrow line between steep slopes of talus. Its bottom formed the bed of a mountain torrent. Its eastern border was a single huge mass whose summit towered probably four to five thou- 
sand feet above the bay. On the west were two peaks, presenting smoothly curving faces toward the valley. Their great bases were somewhat convex vertically also, and were distinctly marked by alternating strata of different material, as if they were of sedimentary origin. At the head of the valley was another peak, similar to those on the west.

We passed through the level plain, by a couple of small lakes, and then climbed slowly up the valley. Our way was sometimes over moss and soil, but more often over broken heaps of rocks of all sizes, piled in confused masses. At the height of 980 feet we reached a very peculiar formation. Between low cliff walls, thirty or forty feet apart, a smooth floor of flat-topped, level boulders had been formed, descending in a series of terraces for two or three hundred feet. It was doubtless formed by the pressure of slowly moving ice constrained within rigid walls. The surface was as flat and almost as compact as that of a macadamized road. A little beyond it the valley, which had been trending true north and south, turned sharply to the right. Just beyond the curve we stopped for lunch, about seven miles from our starting point.

Our surroundings were marvelously beautiful. All about us towered the massive bare cliffs of the mountains. At the bend of the valley a foaming stream of water descended in almost vertical falls and rapids from a height far above. Another stream came down the upper stretch of the valley into which we had turned. At our feet lay a deep, clear pool, fed from a snowbank lying between narrow walls of rock. Here we were well sheltered from the wind, which had been strong and chilling all the morning. While we were lunching the sky cleared and the sun came out, and the 
rest of the day was warmer and more pleasant. At 12.20 the temperature was $53^{\circ}$, and the barometer indicated a height of I,OIO feet.

On resuming our journey, we deserted the valley and attacked the mountain to the north directly. First we scaled a precipitous cliff at a break in its wall, then mounted over a steep, soft talus of shale, and thus gained a considerable level of smooth soil. Beyond the latter we climbed another steep wall, crossed a plain of shale fragments, climbed along a gradually mounting series of smooth, slanting rocks, gained and passed over a long, ascending bank of snow with a precipitous drop at its right, then crossed a long series of small serrate ridges, and finally attained the pinnacle of the pass, 2, I50 feet above the sea. The summits that had become familiar to us along our route thus far still towered above us, probably to double our own elevation. Beyond, to the north, lay a new series, extending as far as we could see.

Our course next lay down through a wide valley, bare and rocky, all ridges and huge loose boulders, with high, bare-sided peaks rising out of it on all sides. Once we passed a picturesque cascade, two separate bands of water leaping over the upper rocks and then joining into one for another plunge. Within an hour we had descended to $\mathrm{I}, 580$ feet, whence our work was alternately up and down over similar series of boulders. To these succeeded a short grassy level. Then we climbed up diagonally over a great field of snow, at whose base the boulders were flattened out into a smooth floor like the one we had seen in the valley of the morning. From the top of the snow drift we crossed a long level, covered over with small fragments of sharp, broken slate, at a height of about I,400 feet. Beyond that a long, 
gentle descent, cut across by two or three rivers flowing through deep gorges, led toward a fertile-looking valley running east and west. One of the river gorges had deep snow drifts lining each side, with high, vertical walls facing each other. Another was completely filled in with snow and ice, under which the river forced its way through a tunnel. The roof of the tunnel made a smooth, easy bridge for our crossing.

When we reached the bottom of the new valley, whose narrow river flows eastward into Sorviluk Bay, we forded the stream and made our camp on its further bank, just below a picturesque waterfall. Our height here was 800 feet. It was then 6.I5, and we calculated that we had walked about I6 miles since morning.

We had much difficulty in finding firewood, and a strong, chilly wind was blowing, so that our supper was prepared and eaten under conditions of considerable discomfort. The sunset, as usual, was not brilliant. There was little or no aurora. The mountains were all capped with clouds. Especially striking was one noble mass that lay just east of the middle part of our afternoon's route, with a huge curved amphitheatre on his side toward us, and a crown of fleecy softness resting on his majestic head and streaming off far beyond it toward the south. A broad peak lying east of us, and north of our valley, was doubtless Mt. Blow-me-down.

The night was rendered uncomfortable by the heavy wind. It was still blowing hard when we arose at 6.20. At 7.35 the temperature was $40^{\circ}$. An hour later we began the fifth day's march. It was first an easy climb over slaty ground up to a general level of about I,200 feet, over which, with slight dips and rises, we marched for several hours. 
Our progress was slow, and we were chilled by rain and fog and by a piercing northerly wind. At one point we passed a large lake, at an elevation of about I,ooo feet, full of little islands and jutting peninsulas, and stretching away apparently for several miles into the fog. The slate deposits continued, and in a few places we found sandstones and conglomerates or breccias. We finally descended from this plateau into a gorge at a height of 850 feet, then climbed rather steeply against a bitterly cold wind, turned slightly westward, and at noon stopped for lunch in a gully where we were sheltered from the wind, at a height of 2,000 feet. A light snow fell about us, the temperature was $37^{\circ}$, and we had to shiver vigorously to keep warm. Our gully was one of the level-floored formations that had interested us the day before. We crossed it, climbed up slightly higher, and then began to descend slowly, having passed the summit of the pass. At our left lay a long valley, far below us, stretching off toward the western end of Ramah Bay, which soon came into sight. A succession of curving summits lay before us, on the right of the valley, and along the flanks of these we marched, keeping at a high level. The summits were all concealed in the fog. We continued walking over long reaches of slate, which finally became smoother. At 4.30 we stopped to take a photograph of the picturesque grouping of mountains across the bay. Three sharp peaks lay to the right, and broader, more rounded ones rose massively further west, with the waters of the bay at their feet. Soon after we stopped again to photograph the mission house. Back of it lay a mountain, ending toward the east in two abrupt cliffs, their feet bathed in the waters at the entrance of the bay, the nearer one bright in sunlight that struggled through 
the thick clouds, the other curving behind it in deep shadow. From these cliffs banks of thin fog were blown out, against which a rainbow was formed, arching from the mission house entirely across the mouth of the bay. Thence we went straight down the remaining 800 feet or thereabouts, reached the beach at 5.30 , and fired two shots to summon a boat from the other side. Our distance thus far for the day we estimated at about I 7 miles. While we were waiting, Adams examined the rock formations near the shore. He found them everywhere composed of slate, containing quartz veins and much iron pyrites.

A couple of small Eskimo boys soon appeared in a boat, and rowed us across the mile-wide bay to the mission house. We were warmly welcomed by the missionaries, who had been wondering greatly over our approach. They were so urgent in their hospitality, so intelligent and sympathetic in their interest in our investigations, and the warm and comfortable shelter they gave us was in such welcome contrast with the conditions of the previous days, that we remained with them until the middle of the following afternoon.

At Ramah we secured an additional guide, Philippus by name, for the rest of the way. We left the mission at 2.20 P. M. of August 24, were rowed about four miles to near the head of Nullatartok or Ramah Bay, and thence started again northward. Our route was at first up easy, grassy slopes, then westward around a high crest, with one of the sharp peaks we had seen in a group of three the day before blocking our direct way to the north. We circled the latter, gradually rising, with a few short descents, into wide and fertile valleys adorned with lakes or watercourses. We were still on shaly ground until toward the last, when we had a 
long stretch of marching over heaps of rocks. Toward seven o'clock we reached a little oasis in this sea of stones, at an elevation of I, 530 feet, and stopped to camp for the night. There was no wood in the vicinity. Our guides gathered heaps of the four-cornered heath-like growth of the Cassiope tetragona, which, being somewhat resinous, made a smoky and ill-burning fire, over which we slowly cooked our supper of venison, emergency ration, and tea. At 8. I 5 the temperature was $39^{\circ}$. Our beds were rather stony, and the fog was settling thickly around us as we crept into them.

On the following day we were up at six. The temperature was then $37^{\circ}$. Disgusted with our experience of the evening before, we made no fire, but breakfasted on raw ration, and started off at 6.30. For some distance we traveled at a general level of about 1,600 feet, between the remaining two of the three sharp peaks. Thence we began to descend through a long valley leading to Nachvak Bay, between a series of summits flanking either side. The first nine miles of our way were over stones; the succeeding four miles were more grassy. At noon we reached the shore of a bight, called Tinutyarvik or Shoal Water Cove, projecting from the bay southward. Finding plenty of driftwood here, we stopped for two hours and cooked a bountiful lunch, using up the last of our venison.

Our guide had hoped to find Eskimos encamped in this bight, who might take us in boats to Ford's. There was no trace of them, however, and we were obliged to travel along the bay westward until we should find them, or, failing that, arrive opposite Ford's house. We rounded the first headland, walking near the shore, covering a distance of three miles, to a second bight. Finding no one there, we crossed 
a river, climbed the hillside west of it, attaining $\mathrm{I}, \mathrm{I}$ oo feet, marched along between the hilltops for three miles, descended again to the shore at a point about four miles from the last bight, and then continued for three miles along the shore. Here we entered a third deep bight, called Ivitak or Brick Bight, the last mile being a stony torture on account of our weary limbs and sore feet. At 6.30 we came to a freshly deserted camp. We afterwards learned that the Eskimos we sought had left there that very day. So our last hope of getting aboard the "Brave" by night was proved vain. We therefore encamped on the spot, cooked a supper of ration and tea, and roasted some dried caplin that we had found on the shore. There were numerous black flies about, but they fortunately seemed to prefer the abundant refuse of the Eskimo camp to ourselves. During our entire stay in Labrador we had hardly any trouble from the flies. Mosquitoes had been a terrible nuisance for about a month, but we had our last unpleasant experience with them during the night of August 20.

On Sunday, August 26, the eighth and last day of our march, we arose at early daybreak, a little before five o'clock. A white frost, the first of the season, covered the grass about us. At 6.15, when we started, the temperature was $37^{\circ}$. The sun was just lighting the tops of the hills east of us, ushering in a splendid day. After proceeding to the head of the bight and crossing the delta of a river that came down through a narrow valley between long series of hills, we climbed the hillside west of it. Our route lay for several miles on high ground, gradually rising in the valleys between the summits to successive higher levels until we were at I,300 feet. Then we went down rapidly to the shore, coming 
out onto a sandy point, near which a tumultuous brook foamed down the hillside. We were then just opposite Ford's house, and the "Brave" lay moored in the shelter of a projecting point near it. Our distance for the morning was about eight miles, and we came to the end of our long tramp at IO.I5. We gladly threw down our packs, fired two shots, and soon again two more, were answered by a flash from the ship, and then were soon again on board.

It thus took us just seven days to complete our trip. Our progress was naturally slow. The walking was, for the most part, over loosely aggregated heaps of stone that filled the narrow valleys and covered the mountain tops; our packs were fairly heavy; and our thin seal-hide native boots, adopted because of the much-worn hobnails of our own shoes, were ill-adapted to so long and rough a journey and needed frequent repairing. We estimated the distance that we had traversed as about 30 miles by water and 90 to 95 by land. The distance from our landing place on Kangerdluksoak (Hebron) Bay to Saglek Bay is about 22 miles; from the north shore of Saglek Bay to Ramah very nearly 35 miles; from Ramah to Nachvak Bay, at the point where we came out, nearly 20 miles; and along the shore of Nachvak to a point opposite Ford's house about 18 miles. The highest point we reached was 2, I50 feet above the sea. We climbed up in all and again descended some I I, 000 to I 2,000 feet. In its general topographical appearance and formation the country we passed over was of two kinds: surrounding the bays on which Hebron and Ramah are situated, the mountains rise more gradually and to lesser heights; on the borders of the fiords of Saglek and Nachvak they are very lofty, and rise often in perpendicular cliffs directly out of the 
water and the tributary valleys. In both sections they are piled up in picturesque and confusing abundance. Their summits and slopes are worn and broken. About Saglek and Nachvak they are more wild and rugged. In the slate region about Ramah they have a softer tone and gentler slopes. Geologically also we traversed sections of different nature and origin: at the extremes of our route the rock. formations are of gneiss cut by dykes of trap-the characteristic rock-materials of the country; in the middle section, beginning about seven miles north of Saglek and reaching beyond Ramah for a distance of at least four or five miles,a total distance of not far from 30 miles, - the rocks are sedimentary, being for the most part of slate, with ocasional sandstone and breccias. Since no fossils have yet been discovered in these deposits, their age is still undetermined.*

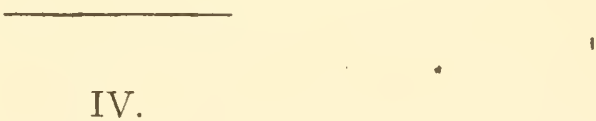

NACHVAK BAY AND THE ASCENT OF MOUNT FAUNCE.

Nachvak Bay $\dagger$ is a deep and wild fiord not far from Cape Chidley, the northern extreme of Labrador, at the entrance to Hudson Strait. Probably there is no wilder and grander scenery anywhere along the coasts of the two Americas than that afforded by the lofty mountains and dark, narrow bays in this vicinity. I should imagine that the famous fiords of Norway must present a very similar appearance. This

* A. P. Low (Annual Report, Geol. Surv. Can., Vol. VIII, 1896. p. 249 L), on the authority of Dr. Bell, calls them Huronian schists. with.

†Compare Daly's sketch-map of Nachvak Bay, reproduced here- 
has the advantage of being more accessible to us Americans, and must surely be as fully worthy of a visit. The bay extends in a narrow body for about 20 miles inland, and then divides into two graceful arms that proceed in south-trending curves for six or eight miles further. We sounded its cold waters in several places and found them attaining a depth of over a hundred fathoms. High mountains surround it in intricate clusters, crowding close down to its shores on every side. At places they rise in perpendicular cliffs directly out of the water; our anchorage was in the shadow of one possessed of the impressive height of 2,500 feet. There are no trees to veil the wonderful beauty of these huge masses, though an abundant and many-hued low vegetation clothes their lower slopes.

The northern shore is comparatively featureless and unindented. Only two coves are known to afford safe anchorage, on one of which is the post of the trading company. Elsewhere the cliffs drop steeply under water to a great depth. The south shore has a larger number of reëntrant bights, into each of which flows a stream of goodly size, fed from the lofty heights to the south and tumbling through a bouldery trough until it spreads into the U-shaped alluvial plain at its mouth. In several of these bights it is possible to find holding-ground for anchors and protection from heary blows. A prominent scenic feature of the north shore is a considerable waterfall, about two and a half miles east of Ford's house. It begins at a height of 700 feet to leap down in short cascades with long reaches between. From the height of 525 feet there is a continuous series of cascades, and all this part of the fall is visible from the middle of the bay. Its final almost vertical plunge is 375 feet in height. 
Steep up from the shores of the bay rises a series of mountains, which attain very nearly the greatest height of any in all of Labrader. North of them, on the coast, no great distance beyond, and northwest in the interior, are the very highest of all, the highest, in fact, of any mountains of the Atlantic coast of North America. They form two classes in their general formation, the two often mingling, sometimes in different portions of the same mountains. Some rise steeply, with talus-covered sides except on the higher parts, to long, sharp, dentate ridges. The others have more gently curving sides and rounded tops, though one or more of their faces may be cut away, leaving perpendicular cliffs, often of great height. The rounded form predominates on the immediate shore of the bay, the former lying further back from its waters.* The curves and outlines of the more rounded are usually of great simplicity, yet possess a massive and vigorous majesty and grandeur. They often hide wild gorges in their folds, where torrents dash down the thinlysoiled slopes; and their cliffs, some of them of great height, are wonderfully imposing. At a distance the rounded sides and summits of these mountains appear smooth and easily accessible, in great contrast with the more rugged outlines

* "All agree in emphasizing the wild, ragged, alpine nature of the relief. From end to end of the (Torngat) range, razor-back ridges and horns abound. These are separated by lower rounded hills and yet more conspicuously by numerous deep fiords and glaciated valleys or glens, the near relatives of the fiords. . . I It would be a mistake, however, to attribute a glacial origin to the rounded profiles of many of the dome-shaped mountains that alternate with the horns. The former are to be regarded as the result of atmospheric erosion and their slopes as the graded surfaces of mountains normally subdued to relatively tame form by that agency. The same stage of development awaits their more acuminate neighbors."-Daly's Geology, p. 224. 
of the sharper peaks. But on closer view their rocky framework is seen to project everywhere, bare and greatly weathered, while their higher portions are concealed under a rough covering of the angular fragments into which their surfaces have been rent by the powerful forces that are at work in their slow transformation.

At the entrance to the bay are two bold headlands, rising outward to the higher summits of Mt. Razorback on the north and Gulch Cape on the south. Thence inland, high, often cliff-broken mountains closely line either shore.* The highest range occurs probably somewhat westward of the furthest waters of the bay. It is penetrated by several rivers, flowing eastward and draining into Ramah, Nachvak, and other bays. Those reaching Nachvak Bay turn after piercing the mountain range, and thus flow into the bay from north and south as well as west. These rivers have their rise in a comparative lowland, covered by an extensive forest, some fifteen to twenty miles from Nachvak waters. Beyond this low watershed is a gentle slope westward toward Ungava Bay, cut by a river large enough to be navigable by small boats.

The alluvial plains on the shore at the ends of the valleys, which are never of any great extent, and the valley sides and bottoms wherever they are not filled in with coarse detritus, are thickly clothed with vegetation. Grass, moss, curlew, berry-bearing Ericacex, are mingled together in a continuous complex-patterned carpet, rich in color and in intricacy of design. Mingled with the greens and autumnal

* The statements that follow in this paragraph are on the authority of George Ford. 
reds of their leaves, and with the greens, reds, browns, and grays of the mosses and lichens, are the isolated bits of yellow of arnica and golden-rod, the blue of the harebell, the pink of lychnis and of the fireweed. Willows growing to the height of seven or eight feet and less, and birches and alders of lower growth, thickly line the borders of ponds and streams. On the lower parts of the mountains the same growths are intricately interspersed with the protruding masses of rock, which themselves vary in color among the softer and harsher tones of black, brown, and gray. The ascendancy in this combination of struggling life and rigid earth is gradually gained by the latter as the elevation becomes greater, until, toward the shattered tops, there occur only rare, isolated specimens of the more ambitious and hardy plants. The steep cliffs and talus grades are destitute of any trace of vegetation, but in many places, especially toward the upper ends of the two arms of the bay, they show a magnificent wealth and variety of coloration, in which shades of red and yellow occur among the more frequent tones of brown and gray.

In spite of their height, none of these summits are buried beneath the weight of eternal snows, and no glaciers plow through the foldings of their sides. Scattered banks and patches of the previous winter's snow linger here and there at all heights, but they constitute a comparatively subordinate motif in the total harmony of the landscape. At this season, freshly-fallen snow may at any time cover the mountain tops. Water, also, except for the great bays and the blue stretch of the ocean itself when these are visible, forms but a minor element of scenic beauty. The rivers are usually hidden among the irregular curvings of the mountains, or conceal themselves among the boulders of their beds. 
Where the valleys widen sufficiently, they hold small ponds or lakes, but this is of comparatively rare occurrence. Only an occasional beck streaks the hillsides with a line of foam. Thus the softening influence of water, snow, and vegetation play a minimal part in determining the appearance of this country, and leave unveiled the beauty of its huge masses. On this account the absence of forests is a boon rather than a detraction. The grandest scenery of Labrador begins with the ragged shapes of the Kiglapait near Port Manvers, continues nobly with the groups at Cape Mugford, and culminates in a magnificent climax at Nachvak.

Nowhere can the student of geology and of the causes of scenery better study his problems than here where nature lays bare the manner of her working, without concealing its stages and effects under the hindering veil of snow or of vegetation. Clear and sharp stand out the evidences and nature of glacial action ages ago, and of the alternate sinking and rising of the land with reference to the level of the sea. Beautifully plain appear the effects of denudation by frost and water, as seen in the shattered summits, the forms of the mountain masses, the accumulations of talus, and the great curves and complexity of the valleys. Standing on one of these heights, one can almost trace out the whole history of the diversification of the original simple ridges into the intricate system of varied peaks and valleys that now exist.

Evidences of the former glaciation of this country are abundant.* Dr. Daly established the fact that the main ice-

* Low (Annual Report Geol. Surv. Can., Vol. VIII, I896, p. 309 L) reports, on the authority of his own investigations and those of Dr. Bell, that there was no glaciation at Nachvak above 340 feet. 



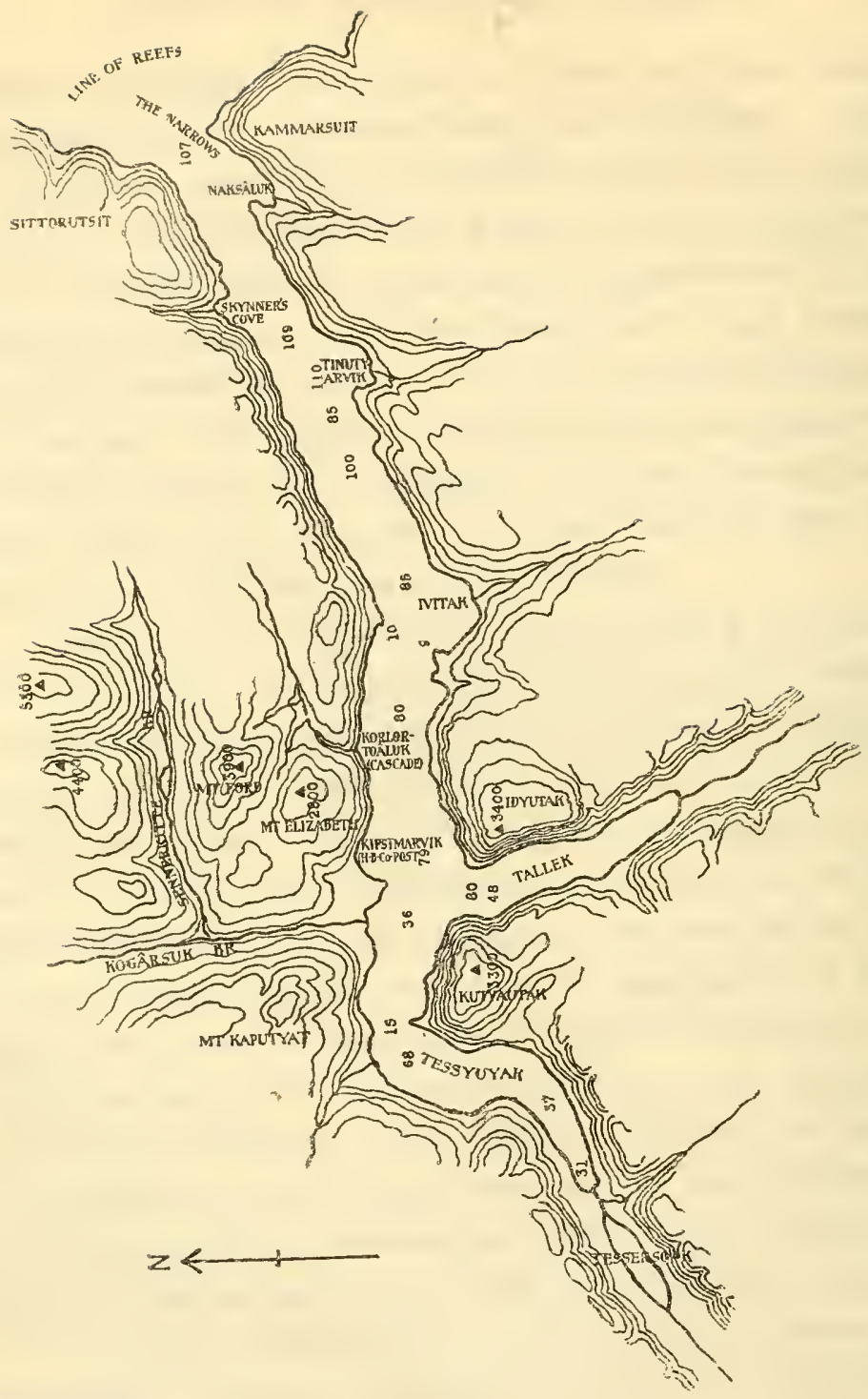

Sketch Map of Nachvak Bay.

Scale: 6 miles to I inch. Contour interval: 500 feet.

Reprinted from R. A. Daly's Geology of the Northeast Coast of Labrador, by permission of the Museum of Comparative Zoölogy at Harvard College. 
sheet did not reach above the level of 2, Ioo feet above the sea, though smaller local glaciers existed in all the side valleys. Below that height he found all the marks of former glacial activity: ice-worn boulders, roches moutonnées, striæ, terminal and lateral moraines: while above it these marks are absent. He found also over twenty hanging valleys, some of them magnificent examples of this feature of the ice work. The movement of the ice-sheet followed the trend of the bay and of the adjacent valleys. He discovered here also, as in previous places, raised beaches and similar results of the postglacial submergence of the country underneath the sea. The highest beach line is at about 250 feet above the bay.*

The bay itself is a typical fiord, in that it is deeper within than at its entrance. Dr. Daly made over twenty soundings in it, going over 45 miles in a small boat for the purpose, and testing all its principal points. The greatest depth he found is I IO fathoms, and it is thus the deepest measured bay in Labrador.

Unfortunately, the days we passed at Nachvak were almost all of them heavily overcast, with thick clouds low down and concealing the tops of the higher summits, so that it was profitless to attempt to scale them. We climbed and measured several peaks, however, and the following pages give an account $\dagger$ of our chief ascent.

On a narrow alluvial flat on the northern shore, just where the two arms of the bay diverge, are the house and stores of the Hudson's Bay Company, which carries on a flourishing trade in furs and fish with the native Eskimos. George Ford, the agent, has lived for over twenty years with

* Low (loc, cit.) places the upper limit at i8o feet.

$\uparrow$ Reprinted in part from the Brunonian, May, Igor. 
his family in this solitary place, far away from his nearest neighbors, the Moravian missionaries at Ramah to the south, and rarely cheered by the sight of visitors. Closely north of his house is a mountain whose height, according to our measurements, is 3,900 feet. Since it was without a name, so far as we could learn, we called it Ford Mountain in honor of our kindly host. Its western flanks abut upon a valley in which flows southward into the bay a river called by the Eskimo the Goratsuk.* Some five miles from its mouth it receives from the eastward a tributary stream, the Shenukatik.* The Shenukatik, therefore, lies in a valley just to the north of Mt. Ford, separating the latter from a series of higher mountains beyond.

Saturday, the Ist of September, dawned with low, thick clouds covering the tops of all the mountains visible from our anchorage. The same unwelcome conditions had prevailed for several days past, interfering considerably with our mountain climbing. We had been at Nachvak now for a week, and had decided that it was time to turn our faces homeward. The day, however, proved unfavorable for sailing, the winds being light and directly into the bay. The barometer was rising, nevertheless, and thus gave promise of an agreeable change in the heavy weather. As the morning progressed the sun came out brightly and the clouds became higher and thinner. Adams and I, who had come to Nachvak together overland from Hebron, had long gazed yearningly at the lofty summits above us, and, therefore, welcomed eagerly

* These names are given by Daly, on the authority of Mr. Stecker, as "Kogârsuk" and "Sennerkitte," respectively. The names used in the text are as given by Mr. Ford, but probably the others should be preferred. 
what seemed to be a favorable opportunity to conquer some of them. To be sure, we would not have time in one day to reach the mightiest peak of Eastern America, though we were certain that it was not far away from us. But we could at least attempt the highest mountain in the immediate vicinity, and thus climb probably higher than any one had ever been in Labrador, and certainly establish a record for the highest measured peak.

It was already late before we decided that the ship could not start, and that it would be a good day for our enterprise. It took but a few minutes to make our preparations for departure, and to get together all that we would need for the trip: a camera, two well-tested aneroid barometers, and a meagre lunch of hard ship's biscuit and compressed "emergency ration." We rowed over to Ford's house, and set out from there at 9.50. The first mile of our way was to the westward, across the alluvial flat at the base of Mt. Ford. Its rich, moist soil, and the lower slopes of the mountains rising out of it, were covered thickly with a sub-arctic autumnal vegetation. The poverty of animal life was in great contrast with this wealth and variety among the plants. We had seen during our stay hardly anything except noisy ravens and hawks, and a small brown-and-white variety of owl.

Our route led us over the boggy level, around numerous diminutive ponds, along a slightly higher and drier grassy mound, through thick willow clumps lining a brook, and thence to the beginning of the uplands of the Goratsuk valley, where we turned to the north. A much-beaten trail, leading to Komaktorvik, another bay farther north, guided us over a part of the way, but we lost it in a short stretch of boggy land and rocks. Beyond us the valley rose gradually 
for a couple of miles, where it was blocked by a group of hills of considerable height. These we might pass either by keeping close to the stream, flowing in a deep gorge to their left, or by following up a secondary valley to a depression on their right, connecting the hills with a flank of Mt. Ford. At first we chose the former alternative, passing over a gradually rising plain corered thickly with grass and moss. But, after nearly reaching the base of the hills, we concluded that we would probably gain by taking the pass to the right. So we cut across in that direction, crossed a small brook, and then went up onto a low shoulder of the hills; whence we turned again north up the new valley, keeping on the slopes some distance above the stream. At the head of the valley was a steep, stony incline, rising to a narrow boulder-strewn pass, a col between two peaks, low-lying offshoots from Mt. Ford.

We climbed the westward peak in order to get a survey of our further route. Its height was I,350 feet, its distance from our starting point about five miles. Behind us, the Goratsuk valley stretched down to Nachvak Bay. In front, the further slope of the col descended steeply as a short, stony valley, debouching into the valley of the Shenukatik. The latter lay stretched out to our right, separating Mt. Ford from another, which, because of a prominent waterfall near its base in the middle of the flank it presented toward us, we afterward named Fall Mountain. This was broad and rounded at the top. Above and beyond it rose two or three snow-sprinkled and cloud-capped peaks, one of which we hoped to climb; though it was now evident that we could not tell which would best serve our purpose without first ascending Fall. On the farther side of the Goratsuk, to the north- 
west, the land rose in a series of remarkable terraces. These were afterward discovered by Dr. Daly to be of glacial origin.

From our lookout we descended across the col and then crossed diagonally, up and down over low, outlying spurs of Mt. Ford, in the direction of the waterfall. A few snowbuntings flew about, and were the only signs of animal life. We had here just the right mingling of rocks and vegetation to make walking easy and rapid. We reached the river, whose height at that point was I,200 feet. Below us it tumbled over rapids and through a narrow rocky bed. Where we were, and for a long distance above, it spread out wide and shallow, with an archipelago of small flat-topped stones projecting just above its surface and lying so close together as to form easy stepping-stones across. To our right, at the eastern end of the valley, was a picturesque series of jagged brown mountains. It was not far from there, over slightly rising rocky ground, to the foot of the waterfall, which we judged to be about two miles from our recent outlook point. Here we stopped for half an hour for lunch. The waterfall was just above us, dashing in one sweep down about 250 feet, and thence in a series of little tumbles into a pool of the clearest and greenest possible water. A little further up the valley we could see a large lake, apparently about a mile in length, so shallow in its middle portion that a group of boulders projected above its surface.

On resuming our journey, we crossed the brook and scrambled straight up the cliffs for two or three hundred feet. Then we climbed slowly, diagonally, toward the eastern end of Fall Mountain, over steep, rocky slopes, a mass of frosthewn fragments of varied sizes. There were no large boulders until we found a group of them near the end. For 
some reason, either because of the nature of the materials, or because of the greater severity and longer action of the frost, the mountain tops here are broken into much smaller fragments than any with which I am familiar in New England, as, for instance, the summits of the Presidential Range in the White Mountains. At 2.30 we reached a point at a height of 3,000 feet, whence we could see the peaks toward which we had been struggling, and which until now had been hidden from us by the curving sides of Fall Mountain. We could see now that there were two of them lying close together. Between them, and between Fall Mountain and the more easterly of them, was a bare valley at whose bottom met the talus slopes from both sides. It rose to a high col just between the peaks themselves, beyond which black, jagged ridges were visible; and descended toward the south into the Shenukatik. The western peak, which we afterward named Mt. Faunce, lay almost directly north of us, most of its lower portions hidden by the curve in Fall Mountain. The eastern peak, to which we gave the name Mt. Eliot, was higher, and descended southward in a long, gradual slope down to the Shenukatik valley. In the latter we could see a series of lakes lying beyond the one we had discovered before. At its eastern end was a very picturesque grouping of serrate and of round-topped mountains.

The tops of our peaks were most of the time obscured by fog. The day was turning out not so propitious as we had hoped. We determined, however, to continue on our way, for, if we could accomplish nothing more, we could at least establish the height of the mountain. Mt. Eliot, as the higher of the two, was the one we preferred to ascend. But it lay farther off, the hour was late, and between us and it 
was a deep valley into which we would first have to descend. Ve could not yet see what would be the conditions in attempting the other. So, before deciding on our final plans, we moved on a little further, rounding the obstructing curve, until we stood near the edge of a precipice that dropped abruptly into the valley far below us. Here we could see that it would be a matter of great difficulty to get down into and across the valley to Mt. Eliot; but that Mt. Faunce was connected with Fall Mountain by a very sharp and narrow bridge-like neck lying but very little below the summit of the latter, and still above us. This decided us to select Mt. Faunce as our objective point. It turned out later that this was much the wiser plan; for from the slightly lower peak we were able to estimate closely the height of the other; the view we obtained from the summit was without doubt very similar and in no way inferior; and had we taken the more distant one we would have been left at dark far from home, with no protection from the coldness of the night, and in a country where it would have been highly dangerous to continue walking in the darkness to keep warm.

It was now about 3 o'clock. We climbed up steeply over the boulders on the projecting shoulder of Fall Mountain, around its summit, and onto the narrow bridge to $\mathrm{Mt}$. Faunce. The height here was 3,400 feet, and the summit of Fall was not more than a hundred feet higher. Thence we went up a series of not very difficult slopes along an exceedingly narrow ridge that fell almost perpendicularly on the west into a deep valley 2,00o feet below, and on the east in sharp talus heaps to the valley separating it from Mt. Eliot. The surface was of finely broken stone. Very little scattered vegetation grew on it, and this was almost exclu- 
sively moss and lichen, with occasional individual plants of grass and very rarely a small flowering plant. Of the latter I found not more than half a dozen varieties. Here and there were patches of freshly fallen snow, but none of great extent.

We attained the summit at 4.30 . The barometer recorded the height as 4,400 feet.* Mt. Eliot, east of us, must probably exceed 5,000 feet in height. The sky was wholly overcast with low-lying clouds. At first we were completely enveloped in fog, but this blew off occasionally, only to be replaced by fresh banks of it rolling up from the south. There were fortunately sufficient breaks to enable us to get some photographs, and to give us glimpses of the magnificent scenery about us.

The material of the mountain is the same as that of which most of Labrador is formed: mainly hornblende gneiss, cut here and there by dykes of darker trap. The summit is of almost knife-like sharpness and very jagged. It is nearly level for about a hundred yards, descends then slightly to the north for a short distance, and then turns sharply eastward, and goes down by a series of steps to the valley. Southward it descends gradually by the slopes we had ascended. The whole of its mass is a narrow ridge, falling with great abruptness in dizzy precipices on the east and west. Mt. Eliot is apparently almost exactly similar in its nature, with a long slope to the south and sharp serrate ridges descending northward from its summit and curving somewhat westward, extending far beyond the limits of Mt. Faunce.

* The barometric pressure at sea-level remained constant throughout the day until after our measurements were taken; the latter, therefore, required no correction. 



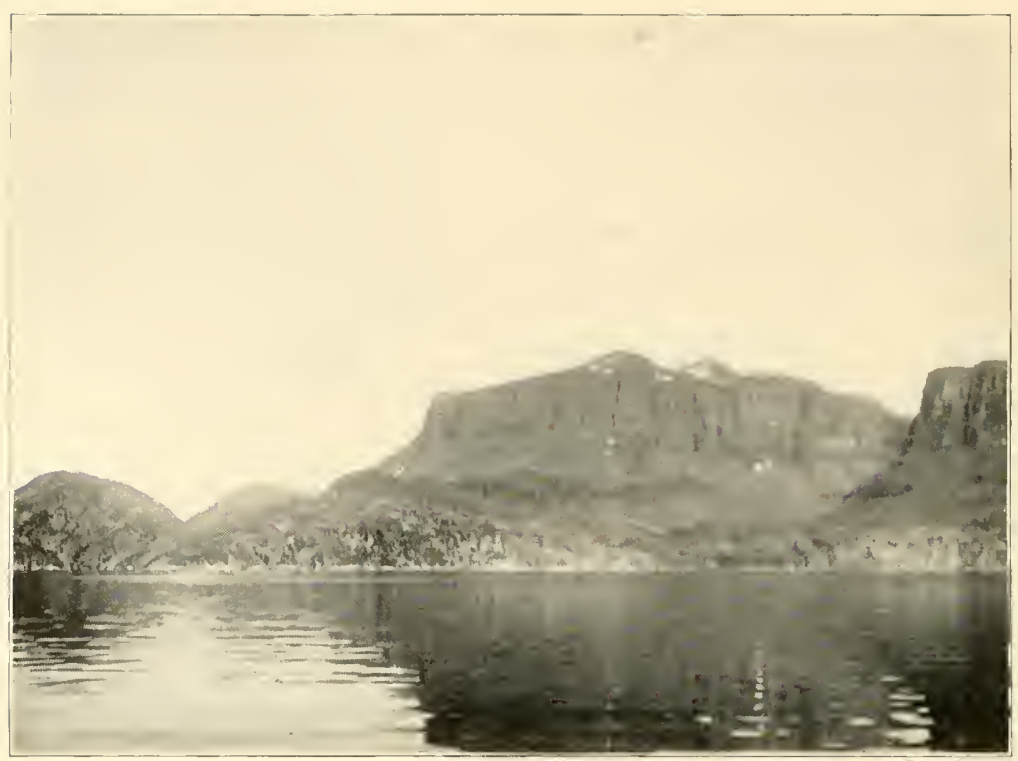

At Mugiord Tickle.

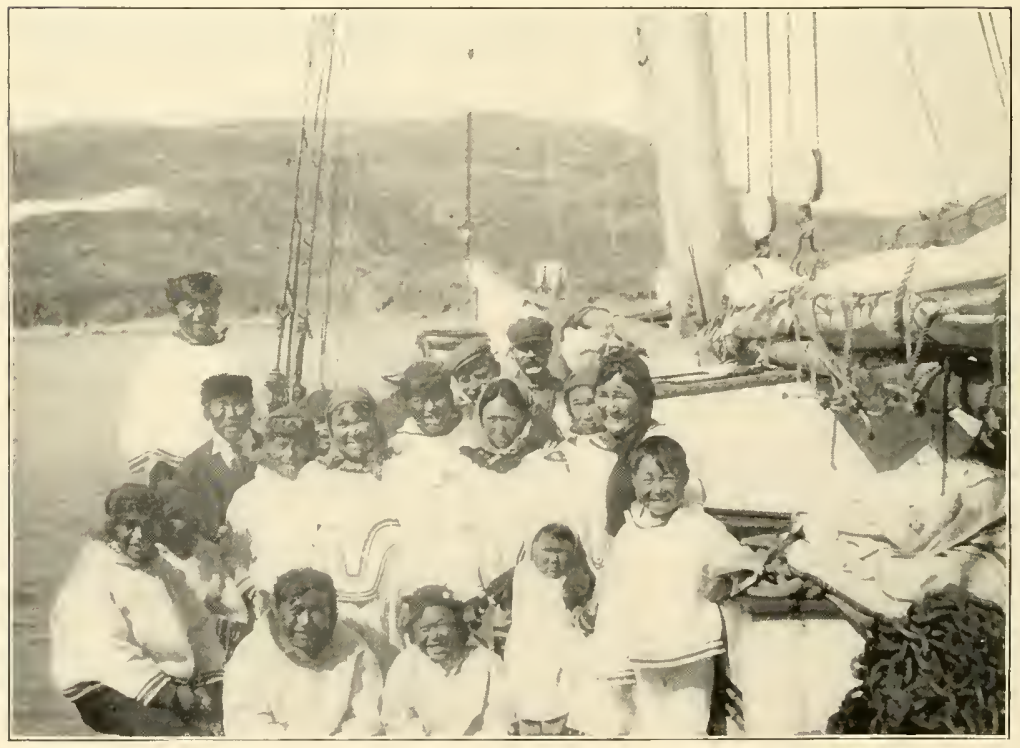

A Group of Eskimos at Hebron. 
North of us and eastward, much nearer apparently than Nachvak, was the beautiful indented and island-broken bay of Komaktorvik. From the head of the bay a broad valley, holding a large river in its midst, extended far to the west. A little west of north, not far beyond us, and cutting off a portion of the valley of Komaktorvik, was another detached lofty mountain. Beyond this and the valley on the north were peaks whose summits were concealed by a continuous low blanket of clouds. Far off to the northwest was the Torngaets range,* stretching from the Atlantic side across toward Ungava Bay, its beatty similarly half-concealed. An enormous raised plateau lav between the Komaktorvik valley and it. To the westward, beyond the Goratsuk valley, and again more to the south, were impressive groups of mountains, some of which seemed to us to rise probably to the height of seven or eight thousand feet. Immediately south, a thousand feet below, was the broad mass of Fall Mountain, and beyond it Ford Mountain, and still beyond the grand collection of mountains on the other side of Nachvak, with some of which we had made close acquaintance on our walk from Hebron. East of Ford, southeast and east from us, a range, at first round-topped and further on more sharp and jagged, limited our view and doubtless bordered on the sea.

At last we turned regretfully away and started to retrace our course. It was then 5.30. We went down the ridge, up around the summit of Fall Mountain to the right, across its broad top, and down over its broken rocks as rapidly as

* So designated on Weiz's map, for which see Packard's Labrador Coast, p. 226. Daly proposes the appropriate term "Torngat Range" as the name for the entire mountain system between Hebron and Cape Chidley, which he regards as a structural and orographic unit. 
we could. On the way I found a pair of caribou antlers that had been shed far up the mountain side, and took them along with me. A brown Arctic owl flew about us in the twilight. We passed the waterfall on its right bank at seven. We had soon crossed the river on the stepping stones, and then hastened rapidly, with much climbing up and down over intervening ridges, to the col at our outlook point of the morning. Thence we retraversed our path to the broader Goratsuk valley at the end of this branch, often almost running in order to cover as much distance as possible before dark. We had not reached the end of this valley, however, before it became so dark that we could no longer direct our course by distant landmarks, and had to go slowly and carefully because even the ground at our feet was but dimly distinguishable. We tried to regain the beaten trail, but were unsuccessful. Bearing to the west end of the valley in the search for it, we got, as we thought, closer onto the bank of the Goratsuk than we had been on the outward journey, and among a difficult collection of unrecognized slopes, cliffs, and tributary brooks. So we climbed up a little higher again, away from the river, and then went on down over steep rocks until we thought we were near the bay. At one place we came to the edge of a vertical cliff, down which we had to lower ourselves with great care by aid of hand-holds and foot-holds far apart. It was exciting work, made doubly interesting because in the darkness it involved a considerable element of danger. Before we were entirely off these rock-ribbed slopes we caught the welcome gleam of a lighted window at Ford's house, but soon lost it again as we descended.

Finally we decided that we were low enough down, and so turned eastward, guiding our course by the summits on 
the farther side of the bay, which were now clearly outlined against the dark sky. We found ourselves immediately in a dense tangle of willows. Through these we struggled with great difficulty for a long while, frequently encountering new masses of them, and finding our way blocked at intervals by pools, around which we had to circle. It was hard and discouraging work, the worst of the entire day. But it was only an instance of that extremity of tribulation that so often precedes relief. We reached the grassy mound near Ford's at last, saw the guiding light once more, and at 9.40 had arrived at the house.

\section{V.}

SCENERY OF THE ATLANTIC COAST OF LABRADOR.

A detailed description has already been given of the magnificent scenery betwen Hebron and Nachvak, and in the vicinity of the latter bay. An attempt will be made here to give a general characterization of the scenic attractions of the country as a whole, and of its variety in different localities.

Labrador lies directly north of Newfoundland, the two being separated by the Straits of Belle Isle, which are 26 miles wide at the eastern end and nine and one-half miles at the narrowest part. It is comprised between the parallels of $5 \mathrm{I}^{\circ}$ and $6 \mathrm{I}^{\circ}$ of north latitude. The Atlantic coast line has an extent of about 800 miles. It is lined throughout its entire extent by mountains that approach close to the seacoast, often rising in steep cliffs directly out of the ocean. In the southern part of the country the heights increase as one goes inland, until they reach a tableland in the interior 
with an elevation of 1,500 feet or more, which forms the watershed for all the rivers.* Further north the mountains are highest close to the coastline itself, or but a very few miles inland. $f$ They begin at the south with heights of from two to seven hundred feet, increase gradually to a medium height of three to four thousand feet in the vicinity of Port Manvers, and then rapidly become still higher until the greatest elevations, of probably six to nine thousand feet, are attained at almost the extreme north, between Nachvak and Cape Chidley.: The height of these mountains, their immediate contact with the sea, and the absence of forests that might conceal their broken outlines, all contribute to make them the basal feature of a coastal region whose picturesqueness is rarely surpassed.

There are comparatively few rivers of any extent on this Atlantic side, most of the larger ones draining in other directions. The nearness of the mountain system to the water on the east prevents the merging of large numbers of mountain streams into one river of any size. A single exception exists in the case of the Grand or Hamilton River, which has its rise in the tableland of the interior and flows into Hamil-

* "The interior country is undulating, and is traversed by ridges of low, rounded hills, that seldom rise more than 500 feet above the general surrounding level. . . . The general level of the interior plateau, . . . near the central water-shed, varies from I,600 to 1,800 feet." (Low, Annual Report, Geol. Surv. Can., Vol. VIII, I896, p. 2I L.)

$\dagger$ "This mountain range appears to be confined to the coast region and probably is under fifty miles in width, the country on the western side sloping rapidly down to the level of the interior plateau." (Low, loc. cit., p. 23 L.)

$\div$ These highest elevations are differently estimated by different authorities. Koch (Deutsche Geogr. Blaetter, Vol. VII, No. 2, I884; see Science, Vol. XI, I888, p. $77 \mathrm{ff})$ gives them as 8,000 to 9,000 feet; Bell (Report Geol. and Nat. Hist. Surv. Can., Vol. I, I885, p. 8 DD) as 6,000 feet. Low (loc. cit.) follows Bell. 
ton Inlet. Its fame rests chiefly on the fact that on it are situated the Grand Falls, over which an enormous volume of water drops a distance of over 300 feet.* Henry G. Bryant, of Philadelphia, who explored them in I89I, writes concerning them: "The Grand Falls of Labrador, with their grim environment of time-worn, archaic rocks, are one of the scenic wonders of this Western world, and if nearer civilization would be visited by thousands of travelers every year. They are nearly twice as high as Niagara, and are only inferior to that marvelous cataract in breadth and volume of water."

Numberless shallow lakes, tarns, and pools are scatiered all over the country, covering, it has been estimated, at least a quarter of the entire surface. $\dagger$ The coastline is exceedingly irregular, indented by many deep harbors and fiords, one of which, Hamilton Inlet, extends for I 50 miles inland. Countless small, rocky islands line the greater part of the coast, extending out from it to a distance of five to twenty-five miles, and affording safe inside runs and secure harbors for the fishing fleet, as well as adding greatly to the attractiveness of the scenery. The soil is everywhere thin and unadapted to the purposes of agriculture, although the missionaries who live here always succeed in raising some of the hardier vegetables and flowers at the expense of great labor and care. But the country is by no means all bare. A plenteous vegetation adorns the land in summer, composed of grass, moss, and a

* Low (loc. cit., p. I4I L) gives the height as 302 feet; Bryant (Journey to the Grand Falls, Phila. Geogr. Club, Bulletin No. 2, p. 32) as 316 feet.

† Low (loc. cit., p. 23 L); but this applies to the whole country extending west to Hudson's Bay, instead of being confined to the limits of Labrador proper as they are now defined. 
large variety of Arctic flowering plants, some of which are of great beauty.

Glaciation, submergence, and erosion have together molded into their present form the original rock-masses of the country. These are almost everywhere composed of the so-called Laurentian gneiss, cut by intrusions of volcanic trap. In some places, however, sedimentary rocks appear, as in the vicinity of Pomiadluk, of Mugford, and of Ramah. The ice of the glacial epoch ground down these rocks, rounded the summits, and furrowed out deep valleys and fiords. "The movement of the ice followed the general slope of the country outward in all directions from a central gathering ground, or névé, and the thickness of the ice was such that in its flow it passed over ridges and valleys unchanged, or with only slight deflections."* The higher summits alone, in the northern part of the country, were unaffected by the ice-sheet. After or during the glacial period, the whole country sank, and the sea consequently rose to a higher level on its shores. Now the land is rising again and stands from two to four hundred feet higher than at the period of its greatest submergence. This gradual uplift has left on all the lower slopes clearly marked evidences of the former levels of the sea. Meanwhile the surface has been broken up and diversified by frost and flood. To a large extent these activities have left the hills and mountains with rounded summits and gradual slopes, both among the lower elevations of the south and the more massive structures of the north. Sometimes, however, other characteristic erosive forms appear, such as the roches moutonnées of Pomiadluk, the round or pyramidal summits bounded by vertical cliffs at Mugford,

\footnotetext{
* Low, loc. cit., p. 290 L.
} 
the "house-roof" formations near Saglek, and the narrow serrate ridges of the Kiglapait near Manvers, and of some of the ranges at Nachvak.

Particularly marked is the contrast betwen the lower surfaces of the south and the bolder, steeper, often more intricately-sculptured ridges that begin north of Port Manvers. In the more southerly portions the coastline, as we have seen, is broken into numerous irregular bays and indentations, its waters crowded with hosts of small islands, and its mainland rising into a continuous series of low elevations. These hills may slope up gradually from the water or present precipitous cliffs rising with sharp directness. In one or two rare localities sandy beaches take their place, smooth and hard, usually of small extent but attaining a considerable magnitude at the Strand near Cape Porcupine. The slopes are usually humpy with irregular projecting naked rocks in the midst of vegetation; but occasionally they take on special shapes, such as the frequently-occurring raised beaches, sometimes of small pebbles and rarely of large boulders, that give evidence of their former submergence; smooth, grassy ascents, that are seldom seen; or the roches moutonnées forms, so prominent at Pomiadluk. The seaward face is varied not only by these rough irregularities of structure and shaping, but also by the different coloring and behavior of its different materials. The grayish gneiss, which is the main rock of the country, softens into comparatively rounded contours; but the dykes of black volcanic trap that cut it everywhere are harder to the air and softer to the sea, and they break into more angular and wild-seeming fragments. Where other rocks occur, such as slates, sandstones, and conglomerates, the variety in coloring and contour becomes 
still greater. Gorges, chasms, sea caves, water courses, form other elements in the total make-up, and all the elements take on constantly differing groupings and variations.

Except for the sometimes precipitous sea walls, the hill slopes, more inland, are almost always gradual, though broken, scarred and seamed, affording a footing for an abundant low vegetation. The sky line is never jagged, angular, and steep. From the summits one looks inland over a country made up of elements similar to those on the shore, except that the steeper cliffs are absent.* Wide valleys stretch out, sometimes of considerable extent, their bottoms covered over thickly with soft, varicolored moss and other growths. Out of them rise low hills, their sides pitted and knobbed with projecting rock and plant-covered hollow. Often every little depression is filled with pools of reddish boggy water; small lakes and swampy bottoms fill in large portions of the valleys; and occasional ice-cold rills trickle or foam among the hills. Toward the north, owing probably to some difference in the perviousness of the soil, these pools become less numerous. The views from the hilltops are enchanting, embracing always a picturesque combination of the peaceful inland rolling country, the feeding-ground of the caribou; of distant mountain tops, row behind row, with snowy patches on their sides; of bays and harbors, capes and

* Compare the following description by Daly, on page 210 of his report: "From any commanding hill on island or mainland, the eye ranges far and wide over a surface showing everywhere the evidence of universal and profound glaciation. Unobscured by forest, soil, or thick drift, and singularly expanded because of the crystalline clearness of the atmosphere, the view typifies that which may be had in the Laurentian Highlands of Canada, or in the Archæan of the Scottish Highlands. It is a great wilderness of innumerable rounded, ice-worn hummocks, generally gneissic in composition." 



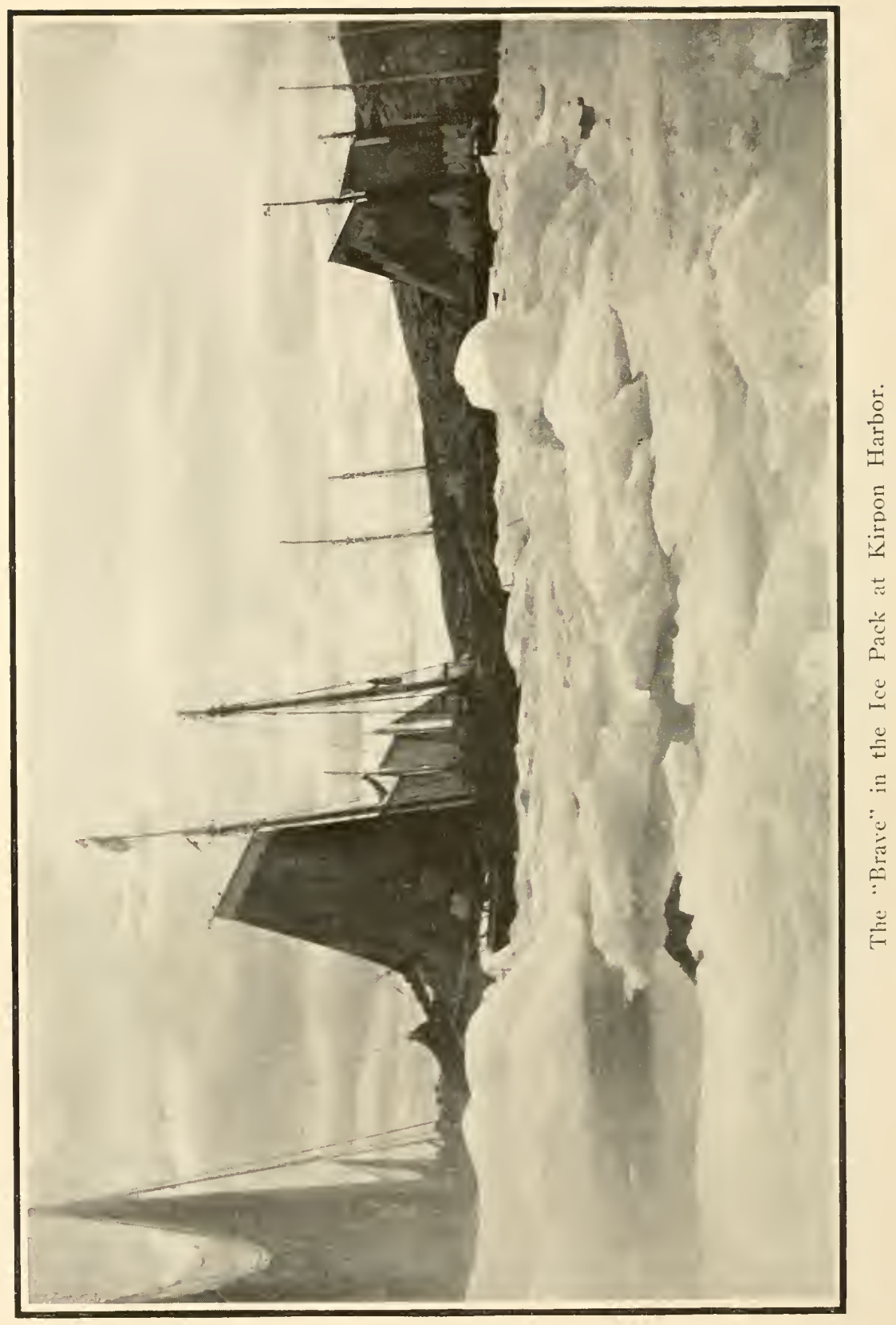


promontories, presenting a much broken and indented coastline; and of the sea, covered often with scattered bergs and ice-floes, and dotted with the numerous islands.

The interior is said to be well wooded and far from barren, even almost to the northern extremity. But near the coast one rarely see trees of any notable size. At Hopedale and Nain there are small groves near the mission stations; but elsewhere we met them only deep in the bays and in sheltered valleys a considerable distance-five or ten miles at least-inland.* Thus, when not entirely lacking, they form an unobtrusive feature in the usual landscape. The low vegetation that predominates clothes the country with a close green mantle, but leaves its shape and natural outline unconcealed. Inorganic nature reveals herself in her own primeval character, leaving all the strength and charm and variety that she can assume naked to observation. There is little of softness, little of the attraction that vigorous organic life can add; though the green of the low plants, the grays, reds, and browns of mosses and lichens, the blues and whites and pinks and yellows of the flowers add a suggestion

* According to Low (loc. cit., p. $3 \mathrm{r}$ L) the limits of trees are as follows: "The tree-line skirts the southern shore of Ungava Bay and comes close to the mouth of the George River, from which it turns southsoutheast, skirting the western foot-hills of the Atlantic coast range, which is quite treeless, southward to the neighborhood of Hebron, in latitude $58^{\circ}$, where trees are again found in protected valleys at the heads of the inner bays of the coast. At Davis Inlet, in latitude $56^{\circ}$, trees grow on the coast and high up on the hills, the barren grounds being confined to the islands and headlands, which remain treeless to the south of the mouth of Hamilton Inlet. These barren islands and bare headlands of the outer coast, along with the small size of the trees of the lowlands, have caused a false impression to be held regarding much of the Atlantic coast, which from Hamilton Inlet southward is well timbered about the head of the larger bays and on the lowlands of the small river valleys." 
of this, yet in a way that never interferes with the stern grandeur of the lifeless masses.

The more northern landscapes differ from those thus far described mainly in the facts that the greater heights attained lead to grander impressions of massiveness and strength, and involve greater ruggedness and variety of form; and that the softening infuences of soil, water, and vegetation are present to a far less degree. Here nature introduces us to her masterpieces of form. Deep fiords with steep, precipitous shores, break into the coast. Islands are few, and the high land contends directly with the unbroken force of the sea. The lofty summits are still often rounded, though quite as often the conditions of erosion have been such that they form long ridges of great sharpness and of jagged outline. The bays and streams have cut off huge portions of the mountain sides, which fall sharply to the narrow valleys, wherein masses of rough boulders are piled deeply, while heaps of coarse talus form a steep transition between mountain and hollow. The projecting buttresses of the flanks often inclose huge basins or amphitheatres. The summits are rent and shattered into bare heaps of broken stones and boulders of all sizes. Plant life is still abundant on the lower levels, but finds little hospitality on the bleak, higher slopes. Watercourses are rarely visible at any distance. Snow is seen in summer only in numerous large drifts and patches, never covering even the loftiest mountains continuously. From the high latitude of the country, its position on the cold side of the ocean, and the great altitude of its mountains, one might naturally expect to find the snow-line at a comparatively low elevation. The reason for its absence doubtless lies in the small amount of annual precipitation, the winter's snowfall not exceeding five or six feet. 
The more southerly part of the coast, with its lower hills and many islands, is full enough of beauty and attractiveness. But the northern part is indescribably magnificent. It is hard to imagine any coastal scenery possessing greater impressiveness and grandeur than is afforded by the serrate ridges and great rounded basins of the Kiglapait; the steep cliffs crowned by the rounded summits of Mugford; the strange symmetry of Bishop's Mitre; the intricate recesses of Saglek Bay, shut in by lofty walls that descend from the worn summits above it; and the massive mountains that crowd together in so great richness of form and grouping about Nachvak.

The charm of a landscape is never exhausted by the conformations of its surface alone, with its attendant growths and other accidents. There are subtler influences of atmosphere and sky, of changing brightnesses and shades, of shapes and colorings varying with the time of day, of transformations wrought by evening light, that are as important to its total effect as are the more delicate bouquets to the flavor of rare wines and fruit. Many of these finer elements are the same in nature and give rise to similar impressions in Labrador as elsewhere. A mere mention of them is enough to convey a realization of their significance. Some special words may be devoted, however, to the more striking and less commonly distributed among them.

The sea contributes a number of effects of especial interest. Thus, mirage is of not infrequent occurrence, and is said by the Nezefoundland and Labrador Pilot to be "characteristic of the few fine days of summer" off the Labrador coast. The fishermen call it "loom." It may be caused by distant low-lying mists, or by heated strata of air. The latter were sometimes clearly visible in certain directions over the 
water, distorting the horizon, or as a thin streak above the calm surface between us and some not far-off island. Schooners and icebergs frequently thus appeared doubled or tripled, in the latter case with the middle image inverted; and with the images sometimes overlapping or sometimes placed one high above the other. During a portion of the season ice-floes are abundant, adding greatly to the picturesque appearance of the sea. For the most part, they are low and flat, composed of pans of various sizes that may be crowded closely together, or at other times dot the water only here and there. Occasionally they are higher, and are then curiously carven by sun and sea into varied shapes, abounding in caves and pillars and overhanging shelves. The green of this ice when seen through the water, the deep transparent blue of its unsubmerged fresh surfaces, and the pure dazzling whiteness of all portions that have been exposed longer to the air, fully justify the enthusiasm of those who have described its coloring. Icebergs may be met with at almost any time and in any number. Their lofty, rugged shapes and great masses are full of variety and impressiveness. On sunny days the kittiwakes and other sea fowl may be seen resting on their sides. Once, as we drove rapidly through thick weather, the fog cleared suddenly and revealed an enormous castellated berg almost directly in our path, standing out against a rough, rocky island; and on many other occasions we met them, though rarely under such picturesque circumstances.

In the evening the phosphorescence of the water is often very marked and striking. The ship moved through streaks of cold fire and left a burning sea in its wake. Fish awakened by the disturbance darted off, invisible themselves, but leav- 
ing trails of dim, twinkling light. Occasionally a bird also would be aroused from his slumbers on the water and fly across in front like a dim shadow. When we were rowing, the water "burned" brightly at the bow and along the sides, and each dip of the oars made a spot as clear as moonlight.

Another beautiful phenomenon of the night time peculiar to these high latitudes is the aurora borealis. We witnessed a large number of brilliant displays, of some of which, occurring during our overland trip, descriptions have already been given. Of two others I have the following notes: "It started with a few faint streaks in the north and east. Then the streamers shot up further, in changing, quivering waves. Great curved ribbons of silvery light developed overhead, with long streamers reaching thence to the horizon in various directions. Then it gradually faded away." "There was another beautiful auroral display last evening, similar in its marvelous light and rapid activity to that of August 2I. The unearthly light danced quickly to and fro, weird and mysterious. It twisted itself into curves and spirals, shot out into bands and streamers, formed ribbons of vertical pickets. These were constantly forming fresh combinations, and along their varied lines flew waves of quivering, almost living, undulations." To these, to complete the impression of the evening splendors of Labrador, may be added this, descriptive of a row across the harbor at Nain: "It was one of the remarkably perfect nights that surely no more southern country can surpass. The moon, not yet three-quarters old, was just rising, sending a gleam of gold across the still water of the harbor. The stars shone brightly, a pale aurora glimmered across the sky, and the water burned under the oar strokes. With its setting of quiet hills the picture was ideal." 
The colors of sunrise and sunset that occurred during our voyage were rarely of any particular beauty. In general they were cold and gray, or, at most, appeared in yellow and violet hues on the hills, or in rosy streaks on the horizon. But of one remarkable sunrise I wrote down a description immediately after its occurrence, which I cannot forbear reproducing here. Its date was August I7, while we were sailing from Mugford to Hebron: "I was called at four o'clock to take my turn at the watch with Harry. We were rewarded by an exceptionally brilliant sunrise. The scene of the performance was framed in by two low islands. Between them lay a bank of clouds, tapering into a thin, long point toward the north, lying close down on the horizon. Above that was a clear space of sky, and then a large group of clouds that formed part of a general massing covering a large proportion of the sky. Directly overhead the clouds could be seen to be thin and fleecy, stretching downward so that their lower parts were at no great altitude. The first signs of the approaching splendors were already apparent when I came on deck. The lower edge of the upper of the two cloud banks was fringed with a reddish-purple, above which the dull slate of the unillumined surface stretched everywhere. Soon this purple brightened into a clear crimson, which gradually mounted higher on the bank until it reached the top, and thence shaded downward into orange hues. Meanwhile the lower bank had assumed the deep redpurple on its under edge, while all the rest of it was a very dark blue-purple. Immediately overhead the fleecy mists were white, and between them and the horizon, and here and there in the midst of the illumined field, dull slate prevailed. The orange band lining the upper bank brightened; the 
crimson spread forth wider; the red encroached upon the blue in the purple of the lower cloud, until it became a mesh of fire. The clear sky between the two banks assumed a light olive-green hue. In it small detachments from the larger clouds made stars and fleecy fringes of orange. A narrow bar of gold shone just above the lower purples. The dark masses of the two islands, curving together just underneath, framed in a picture of wonderful coloring. The crimson crept higher and wider, and lighted up the low-hanging edges of the clouds above us, reaching finally around to the farthest west. Broad bands of brighter light began to radiate out from the centre of illumination, exactly as the conventional picture always represents the rising sun, the reverse of the shadows on far-off mist that are popularly supposed to be 'the sun drawing water.' Into the struggle for supremacy of the two purples in the low-lying bank entered a new element, a tangle of living gold. After this the blues gained over the reds in the duller purples below; the crimson gave place to yellow; the line of gold on the higher bank broadened and brightened; the variety in coloring gave place to increasing illumination, until at five o'clock a narrow opening directly on the horizon, in the centre and bottom of the almost meeting curves of the islands, gave a glimpse of the sun's burning gold, and soon his disc had struggled above the lower obstacles and gleams of cold sunshine fell on the ship and the dark faces of the furrowed cliffs of the shore."

In concluding this characterization of the scenery of Labrador, I cannot better emphasize the preceding account of its peculiarities than by giving from my diary a few extracts descriptive of particular localities.

Of the islands north of the entrance to Hamilton Inlet, 
July 24: "The islands, as we approached, though not very high, yet presented a very picturesque appearance, mainly due to ragged, angular, narrow dykes of trap protruding through the rounded softer rocks. Packard says of this region: It 'is in places very high and rugged, owing to the presence of trap dykes and ancient volcanic overflows capping the hills of gneiss. Huge dykes of the black rock ran in ruffled crests over the hills of pale, gneiss-like, huge black walls. . . . Owing to the great outbursts of black basalt capping the light gneiss hills, and running in ridges or forming great splashes on the faces of the hills, and sometimes entire hills, like craters, the hills are transformed from what would otherwise be quite tame elevations into high, bold, wildlooking peaks.' Except for these black intrusions, with their irregularly broken outlines, the hills were rounded and green with vegetation; but the green was not that of our own wooded hills, but a close-lying tinge of color, with bare rocks and cliffs projecting through it."

Of a chasm on one of the Seal Islands, September 20: "After" anchoring, we went ashore on Long Island. Its most remarkable feature is a deep chasm extending almost the entire width of the island, narrow, with steep, straight walls, between which the breakers roll noisily at the bottom."

Of Pomiadluk, July 3o: "We found a country that well repaid us in its interesting features and wild grandeur. A mountain range rises up from the shore where we landed, and we climbed one peak which, by Daly's barometric readings, was I,I70 feet in lieight. It rises in two slopes: the lower one fairly gradual, with a level plain at its top half a mile in width at a height of 390 feet, and then a much steeper upper slope above it. The appearance of this mountain is 



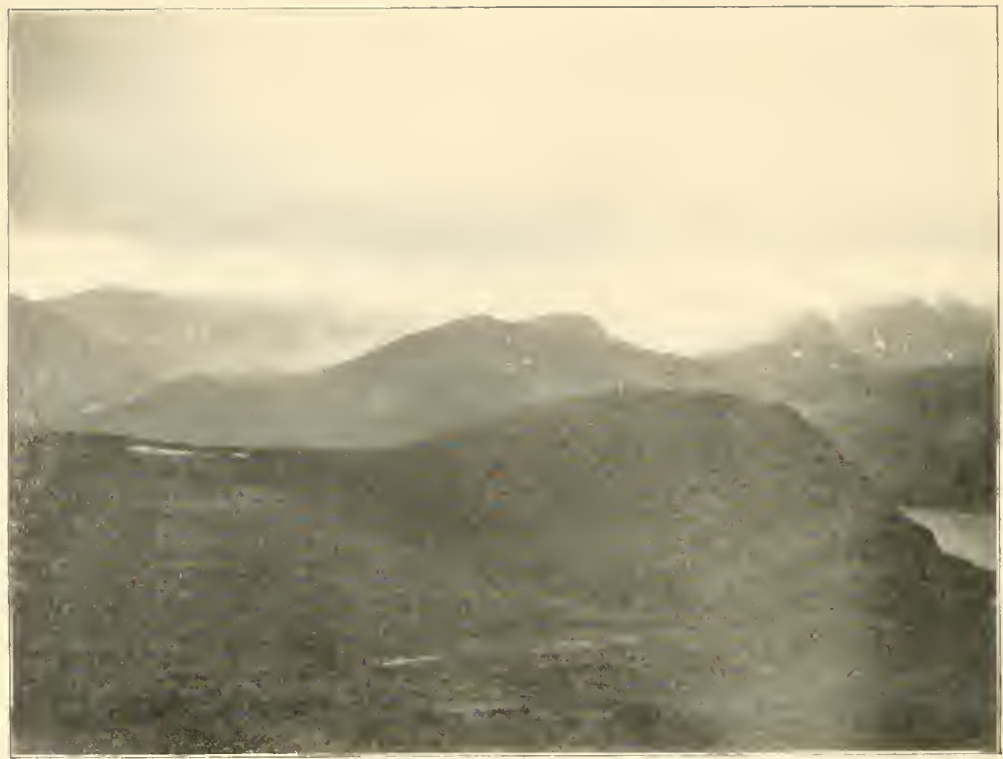

Mountain Group at Nullatartok (Ramah Bay): Jooking north.

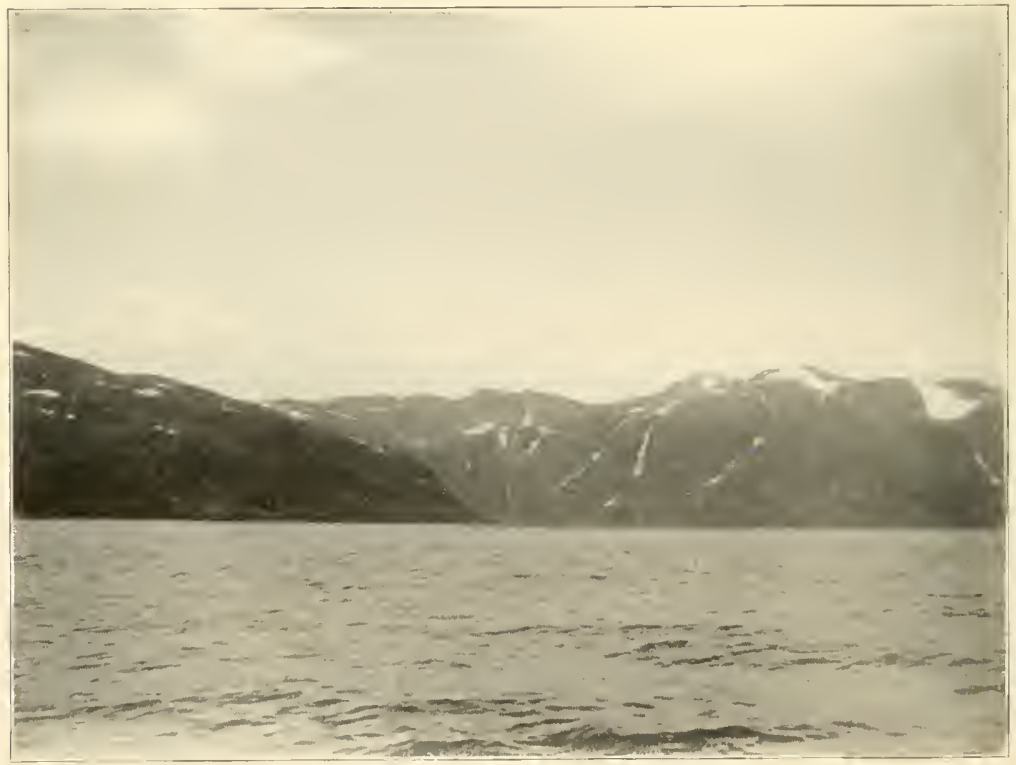

South Shore of Nachak Bay, near the Narrows. 
vastly different from anything we have previously seen. The whole lower slope is made up of long, smooth, rounded ridges of massive rock, absolutely bare of vegetation, with deep fissures between them in which soil and vegetation have gathered. The long axis of these rocks runs nearly northwest and southeast, sloping downward toward the southeast. A cross section at right angles to the long axis shows a gradual slope up the southwest side, a rounded top, and a steep dip toward the northeast. This is the shape characteristic of what are called roches moutonnées, and is due to glacial action, the ice having moved in the northeast direction down the slope of the mountain. We found many glacial strix marking its course, and an abundance of the lunoid markings mentioned by Packard, whose origin is still a matter of dispute. We found them even up to the very top of the peak, much higher than they have previously been seen. They run in little, straight groups, taking the same direction as the strix. . . The material of most of the rocks is of volcanic origin: diabase, granites, etc.; but there occurs also a large amount of metamorphic conglomerates, with beautifully exposed surfaces, the large green and pink pebbles within it having become greatly flattened under enormous pressure. These conglomerates are the first we have found in Labrador.

"The whole of the lower slope has been submerged, and the sea has washed out most of the glacial drift between the ridges of rock. Daly found raised beaches up to 360 feet, showing that this region has been raised up much higher than those further south. In one place is an enormous gorge with steep, wild cliffs on its sides, in which hawks have their nests, and with its floor covered with small boulders. It belongs 
to a beach 250 feet high. The extent of the slopes thus formed must be several miles in breadth, and a mile or more in upward direction. The higher rocks on this lower slope are more rough, broken, and weatherworn, interspersed with a great deal more of vegetation; and some large stretches exist where an abundant soil and its growths reach down close to the sea. But a very large proportion of these lower rocks are as smooth as if the sea had just receded from them, are almost as bare of vegetation, and are tumbled together in huge masses, ridge rising above ridge, of a perfect hummocky shape. This part of the mountain presents a magnificently impressive landscape.

"The intervening plain, perhaps half a mile in width in places, is composed of a pebbly floor covered with characteristic Arctic vegetation. A number of small ponds lie upon it. It may have been formed by sea action, thus marking the upper limits of submergence; or it may be the washings down from the higher parts of the mountain. From it the final peaks rise steeply. They are composed of rocks of the same hummocky formation as below, but have their outlines much softened, both because of the greater steepness and because the sea has never risen over them to remove the glacial deposits. We found a number of long, steep snow drifts, which were of assistance in climbing up. As we approached the top, a rosy tinge on dark leaden clouds showed that the sun was not yet set. A few gentle showers fell before we descended. From the top the view was a wonderful one. Just under the peak beyond us was a large lake, probably nearly half a mile in diameter, containing an island, and with a few jutting points reaching into it. In the northwest, though it was already nine o'clock, the sun was just setting in a bank 
of clouds, and other clouds above it were lighted with long bands of brilliant gold and rose. A ruddy light gleamed over the whole surface of the lake. To the north and west rose groups of higher mountains, range behind range, with an occasional lake or arm of the sea visible between them. The farther ones were covered with a purple haze. To the south and east was the sea, forming a long, irregular line at its juncture with the mainland, and covered with the numerous islands of the Adlavik group."

Of the view from a hill at Ford Harbor, August 8: "The view is one of the most enchanting I ever saw. High mountains most picturesquely grouped, islands without number dotting the sea, and a general combination that could hardly be surpassed."

Of Port Manvers, August II and I2: "The mountains hereabout are high and steep, very impressive in their appearance. They are made of very friable rock, forming coarse gravel at their bases, and beaches of fine sand in the protected bays. Mt. Thoresby, south of the Port, is 2,733 feet high. It rises gradually on its southern slopes, but falls very steeply, with much gullied sides, to the harbor. ... We traversed three miles of sandy beach, climbed a steep rise to an enormous gravel plain that was once a shallow bar connecting a rocky island to the mainland, but now lies I 70 to 200 feet above the sea; then up the course of a brook, across a damp, soggy level where our feet sank deeply into the soft moss and turf, and up steeply along another stretch of the brook into a narrow valley lying between two round, green hills perhaps 1,500 feet above the sea. . . Thence we climbed up the steep mountain side to the right, over a precipitous snow bank, and onto the top. On one side, 
across the Port and stretching on beyond its head, were the steep flanks and knurly sides of the Thoresby group; on another side the sea; and in front stretched out the deer country-a wide, level plain, filled with small lakes, and interrupted by numerous low hills rising out of it like islands. We could see around for many miles. A Labrador landscape has decided charms of its own, in spite of the lack of trees. Where the naked rocks project or cliffs fall steeply, they produce an impression of strength and grandeur. But the country is not all made up of mountains and bare rocks. Vegetation is abundant, and many of the rounded hills are green with moss and grass. The low, thick scrub relieves the closeness of the other growths, and produces a velvety impression at a distance. The hilltops here are not bestrewn with little pools, as we have found them in some places; but the lower ground has an abundance of water and thick, mossy growths of many colors."

Of the Kiglapait, August I3: "The most striking part of the coast we passed was the Kiglapait, a high ridge a little north of Port Manvers, which the Pilot says is not less than 2,000 feet in height. Daly, who is good at such estimates, believes it to be about 3,800 feet in height. Its summits are long and jagged, stretching out one after the other in a long series.* They fall sharply to a long, low, rounded hill lying in front of them on the seashore, and have

* See Daly, loc cit., pp. 218, 267: "The axis of the range runs due east and west, parallel to the coast line, which here has an exceptional trend. The sierra is not more than thirty miles in length, but, on account of its conspicuous position on the shore, is strikingly picturesque. Ten distinct and individual summits from two thousand five hundred to four thousand feet in height could be counted from the schooner... . The Kiglapait is unmeasured, unmapped, and absolutely unknown as to composition." 
a series of inmense amphitheatres scooped out of their barren sides."

Of Cape Mugford and of Bishop's Mitre, August 15 and I6: "We are in a bight on the south side of Cape Mugford, at the entrance to its Tickle. North of us lies a pair of remarkable peaks. One of them has two smooth, round summits, the other a more irregular one, about 3,00o feet in height. Below the summits the slope of the top ends abruptly in vertical cliffs, furrowed with perpendicular lines and showing horizontal strata that curve downward at the east end and dip steadily until they meet the sea. Except at this end, a long slope of talus lies at the foot of the cliffs, cliff and talus together measuring probably a thousand feet. At the lower end of the talus are other lesser cliffs, finally ending in comparatively low, irregular hills at the water's edge. . . . $\mathrm{W}$ e found the cliffs inaccessible. Adams and I climbed to I,225 feet at the far western edge of the peaks, up to the foot of the main talus. Between the two peaks we found an incurving gorge, the cliffs continuing throughout its whole extent and joining together the two mountains. At its inner angle a beautiful waterfall makes a drop of probably 250 feet, and then runs off in a curving brook through the short valley. . . Nothing can be more delightful than a sunny Labrador day in midsummer, especially at sea, away from the plague of mosquitoes, and with stupendous scenery to gaze at with its constant changes and developments. We got away about nine o'clock, with very little wind. Our course lay through the narrow Mugford Tickle, close by the foot of the cliffs described yesterday and northward beyond. The views we had of Cape Mugford on its different sides were grand beyond description. We passed under its cliffs where they 
drop most steeply directly into the sea. An occasional narrow waterfall foamed over their rugged sides. As we approached the northern end, the sea opened out again on either side, and we had a repetition on a larger scale of similar formations to those of the southern side. To the eastivard, four or five miles out at sea, lay the inaccessible peaks of Nanuktut or White Bear Island. The mainland stretched off irregularly to the northwest, with a multitude of sharp, snowy peaks crowded along its length. As we progressed, these came out one after another, showing deep gulches and ravines between them and giving a series of most majestic combinations. At the northern extreme of the Cape is the Bishop's Mitre, which, from every point of view, is deeply impressive. Its summit as we first saw it appeared to be a single bare pyramid, which reminded us of the summit of the Matterhorn. Up to its 3,000-foot base led in one place a continuous steep slope uninterruptedly from the sea; but elsewhere the descent, though various, was steeper. As we got further north of it the companion of the first peak became visible, the two together being responsible for its name. Toward evening it appeared to greatest advantage. We were then almost directly north of it, and from base to summit it presented an almost perfect symmetry. Above were the twin pyramids; on either flank was a massive buttress stretching forward and outward, with a sharp downward curve from the Mitre itself, and a shorter upward curve with jagged outlines to the lesser peaks at the side. These fell in sharp lines to the sea; and between them they held, backed by the body of the mountain, an immense hollow basin, from which, exactly in the middle, a line of snow ran up at the angle at the back to the notch between the pyramids." 


\section{VI. \\ LIFE ON THE LABRADOR COAST.}

The Atlantic coast of Labrador is probably ordinarily considered bleak and almost uninhabited. In reality, it supports a considerable population. In our brief voyage it was impossible for us to meet a very large proportion of the inhabitants, or to study them with any large degree of thoroughness. The present account lays no claim, therefore, to careful scientific accuracy and completeness, and does not pretend to contain any new contributions of value to knowledge. It aims rather to give the impressions we gained of the people both from our personal contact with them and also from the descriptions we received of them from missionaries and others whom we met. These impressions may be inadequate in some respects, in consequence of the inadequacy of our sources of information. Yet, even so, it will probably be of interest to give such account as we can of the conditions of life there as we found them or heard them described. A considerable portion of this section has already appeared in the Providence Sunday Journal, and is here reprinted with permission, with a considerable amount of additional detail.

A thousand miles or more of desolate seacoast stretch from St. John's, in Newfoundland to Nachvak, near the northern end of Labrador. In the summer time it is crowded with fishing schooners, whose crews toil laboriously for their scanty winter supplies. But in the winter, except for a few widely-separated and lonely settlements of hardy natives and whites, it is inaccessible, and given over to the undisputed sway of ice and snow.

The visitor to these shores finds much to interest him. 
If he be a lover of nature, he will find few more beautiful and attractive regions than this, with its irregular coastline, diversified by rocky hills, imposing cliffs, and island-dotted bays; with its many-hued Arctic vegetation; and in the north with its deep fiords and huge mountain masses. If he be a scientist, its plants, its geological formation and history, its animal life, will give him plentiful opportunity for study and new discovery. The sportsman will revel in brooks teeming with trout, or may haply discover big game worthy of his rifle. The mere traveler, seeking new sights and adventures, will come away enthusiastic over the novelties of a summer in the far north, where numberless icebergs, a brilliantly phosphorescent sea, a sky often alive with wonderful quivering displays of auroral light, a season of continuous autumnal comfort, and the strange, impressive landscapes of a sub-arctic country, have given him a bountiful reward for his journey.

Yet, after all, wherever one may go, it is the human life, with its varieties and occupations, its differences from ourselves, its triumphs, vicissitudes, and problems, that furnishes the study of most absorbing interest. This is certainly true of Labrador. Simple, rugged, and primitive, like the land they live in, its people present features of interest alike to the psychologist, the anthropologist, the student of social economy and conditions-and naturally, also, to the practical philanthropist.

Eskimos.-Of the aboriginal inhabitants, aside from the Indians of the southerly interior, there are now only about a thousand Eskimos along the Atlantic coast. From Hopedale southward most of them are of mixed blood; but north of there they are said to be almost entirely pure blooded. We 



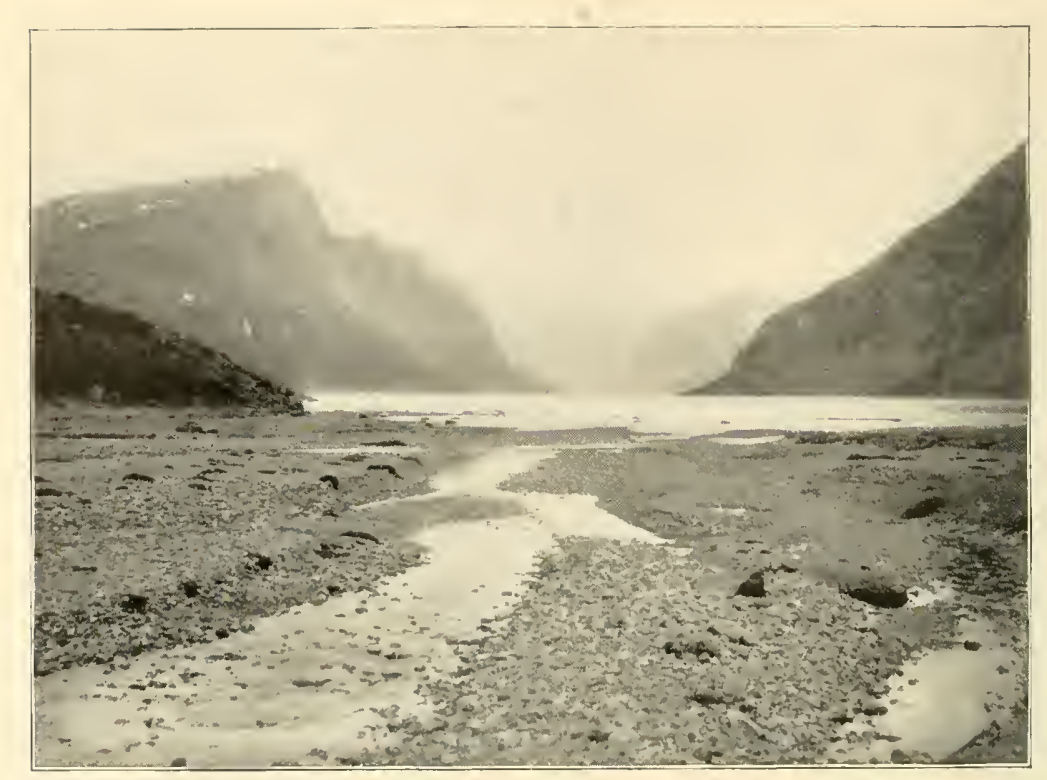

Mouth of Kogarsuk (or Goratsuk) River. Nachvak Bay; looking toward the Tallek.

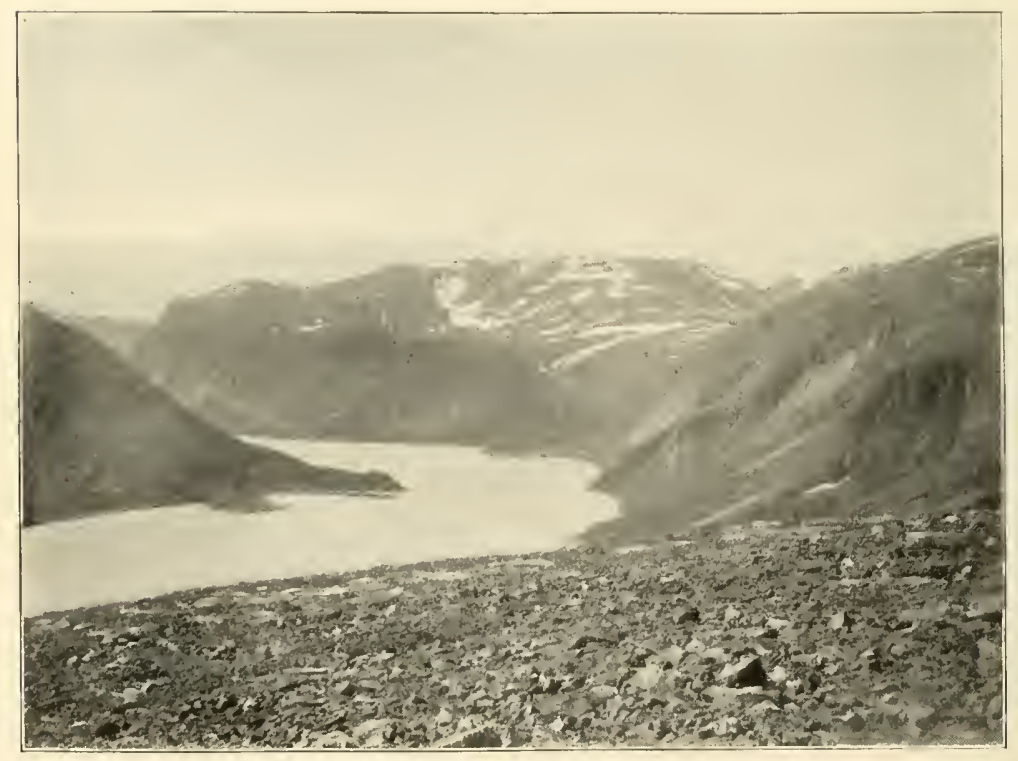

The Tessyuyak; the Southwest Arm of Nachvak Bay 
met them frequently north of Hopedale. Their present southern limit is Hamilton Inlet, though in former times they are reported to have spread as far south as Massachusetts. They swarmed over our schooner, peering curiously into all its recesses, and offering their simple possessions in exchange for tobacco and clothing; and we met many of them in their villages on shore. We find them here not in their original crude condition, but greatly modified in dress, manners, and customs by their long contact with white men. The Moravians sent missionaries to these coasts more than a century and a quarter ago. In consequence, the Eskimos who have come under their influence have adopted many features of civilized dress, implements, and beliefs. It is only further north or west than we penetrated that we find them unchanged.

The men look strong and sturdy. They are rather short, seeming to average about five feet and a half.* Their heads are very long from front to back, as compared with their breadth; the cephalic index, according to the anthropologists, averages about 75 . Their faces are broad and

* Statements vary as to their height. Low (loc. cit., p. $52 \mathrm{~L}$ ) says: "The males, as a rule, are quite as tall as the average white man, but owing to their broad, heavy build, they appear shorter than they really are; and this appearance is enhanced by their wide garments of hairy deer or seal skins. Where seen by the writer ... several of the men were six feet and upward in height, the average height being about six feet five inches." Deniker (The Races of Man, 1900, p. 578) gives the average height of twenty-six measured Eskimos of Labrador as five feet two inches. Robert Brown (Encycl. Brit., VIII, 543) says they measure five feet four inches to five feet ten inches, and in rare cases even six feet. The cephalic index (Deniker, p. 587) is 76.8 for the living subject, as measured on 6I4 Eskimos of Greenland; and for the skull has been found to be 72.4 for 31 cases from Greenland, 7 I.3 for 152 cases from Eastern America (measurements of Davis). They are said by Ripley (Races of Europe, I899) to be almost the longest headed race known. 
round, with projecting cheek-bones and prominent processes. at the upper end of the jaw. They are usually very fat. The jaws, or at least the lips, are very apt to be rather protuberant. The eyes are narrow. The forehead, usually covered over with hair, is of medium height. The hair is straight and jet black, except in the case of the old men, and is worn long, cut off straight below the ears and just above the eyes; though some of the younger men wear it close-cut. The beards are very thin, and often entirely wanting. When there is little fat in the face the prominent bones, and the deep wrinkles in old people, make it of very irregular outline. The eyes and the complexion are always dark, but the latter varies from the color of a moderate sunburn to a much deeper brown. Where the skin is not exposed, however, it is apparently as white or rosy as that of a white man.

The women closely resemble the men in their features. Their black hair is done up in a coil on the head. Most of them now wear skirts, especially when strangers are about, though some of them still cling to deerskin trousers. One feature of their original dress that they still retain, and that serves by its different form to distinquish the men from the women, is the jacket or attigi. It is a loose garment, furnished with a hood for both sexes. It is cut square across at the bottom for the men, but for the women ends below in a curve or tail both in front and behind, the rear appendage being much the longer. The hood is often bordered with fur, and in the case of the women bears more or less elaborate ornamentation. These garments were doubtless made originally entirely of fur, but this has now been supplanted, in sumner at least, by a white, thick, flannel-like cloth supplied by the missionaries. The hood of the women serves not only 
as a head protection, but also as a convenient receptacle for the babies.

These people are of an essentially sanguine temperament. Of course, they differ much from one another individually, but there are many traits that are true of them in general. They are naturally cheerful, merry, and light-hearted. They are fond of song and music, and have some skill in its production. They seem to be often joking together; are jovial and good-natured, with a well developed sense of humor. These sunny qualities give place at times to darker moods. Quarrels may arise; stealing may occur, though it is rare; murder may be committed, but Mr. Ford, of Nachvak, has known of the occurrence of only three cases. Their emotions are apparently not deeply seated or persistent beyond the immediate presence of the exciting cause. They are almost always honest and peaceable, and friendly to the stranger. Warfare is almost unknown among them. They naturally resent injury, as when, as too often happens, the Newfoundland fishermen encroach upon their fishing grounds or steal their wood for huts; but they rarely resort to violence, and when this occurs it is usually under the lead of some one with white blood in his veins. They have an excellent reputation for industry, are active, quick, enduring. Whenever we employed them, we found them willing and eager. They lay by little for the future. When they have plenty they are pretty sure to be generous, and a good hunter will support sometimes several families, the rest being content to live lazily by the exertions of the one. They can be just as greedy as they are generous, when circumstances are different. They have a good average degree of intelligence-a high degree, 
it would seem, when one considers the few solicitations to thought and ingenuity in their environment; but their intelligence is combined naturally with a great deal of superstition. They are easily led, and their special character and actions depend much on the nature of their leader. Yet they rarely have any sort of government, but live together in tribal amity with no chief or ruler unless one temporarily arises by virtue of his own unusual gifts of wealth or wit. Where their primitive ideas are not weeded out by the missionaries, however, they are largely in subjection to their medicine men or sorcerers.

Where missionary influences prevail the marital relations of the Eskimos are of the conventional civilized type, and their sexual morality is of a high order. But further north they vary much, each doing much as he likes and can. One man may have three or four wives; and at least one case is known where two men have one wife in common.

The life of the Eskimos is one of hunting and fishing. They live principally on a meat diet, consisting chiefly of seal, whale, caribou, and fish. Berries are almost their only natural vegetable food, though now they obtain also flour and bread with considerable ease. Formerly they did little cooking, but now the introduction of civilized kettles makes it easier. They place their main reliance on the seal, and it is hard to imagine how they could continue to get along without it. It gives them food, dog meat, clothing, boots, tents, dog traces, and harpoon lines, fuel for light and heat. They have little in the way of implements and possessions except such as are needed for their hunting and fishing, for clothing, shelter, and food. Once they lived very crudely, with no implements except of stone, of bone, and of skins, 
no fuel except seal oil, and no domestic animals except their magnificent dogs. One still finds in old graves specimens of these cruder implements formerly in use. But a hundred years of contact with the white man have given them many of his utensils and methods. A few useful articles remain much as in the days before they knew the white man and his ways. One of these is the kayak, a rapid and seaworthy canoe made of skin, entirely decked over except for the round hole in the middle in which its one occupant sits. Another is their remarkable harpoon, whose barb detaches itself from the handle when the animal is hit, and, being attached to a float and drag, prevents the escape of their game. Still a third is the komatik, or dog sledge, in which the only important change has been the substitution of iron runners for those of wood, bone or frozen mud formerly in use; though runners of ivory or whalebone are also still used.

Most of the Eskimos now live in small communities of not more than three or four hundred about the mission stations or the posts of the Hudson's Bay Company. Usually their crude houses are of wood covered over on the outside with turf; though in some places they are entirely of wood. In former times their central dwelling was constructed of walrus or whalebones covered over with skins, or of an underground excavation, or of a half-underground, half-over ground framework of stones covered with turf. One still sees remnants of such structures. They often leave these more permanent dwellings, however, and go off, in the summer for fishing, in the winter for hunting or sealing. It is only on these occasions that they now use their snow houses in winter, and in summer their skin topeks or canvas tents.

The conditions of their life, with the continual necessity 
of warm clothing and shelter, and the difficulties of obtaining warm water and soap, naturally render impossible any large degree of cleanliness. Yet they tolerate a rather unnecessary amount of filth and refuse in and around their dwellings, which, with their utter disregard of ventilation, while less offensive and less deleterious to their health than the same conditions would be in a warmer climate, are nevertheless harmful to a considerable extent.

Many of them have considerable skill in making carvings of the ivory of walrus tusks. They do not, however, possess the fine feeling for ornamentation and finish shown by their Alaska kinsmen. This, together with their music, seems to be their only art. Their language is highly polysynthetic, single words of complex structure taking the place of whole sentences. There is a remarkable similarity in its dialects everywhere, from Siberia to Greenland. They differ hardly more from each other than do English and broad Scotch (Keane, Man, Past and Present, I899), in spite of the separation of some of the tribes from each other for perhaps thousands of years.

Moravian Missions and Hudson's Bay Company Posts.The most important centres of population in Labrador are about these two classes of posts. The Moravians founded Nain in 1771 , Okkak in 1776 , Hopedale in 1782 . Later they established missions at Zoar, Hebron, and Ramah. Recently Zoar was given up, and in 1896 a new station was established at Mokkovik. This last has no Eskimos about it, but exists for the benefit of the settlers between Rigolet and Hopedale. Okkak is their largest settlement, with about 300 Eskimos. Aside from Mokkovik, Ramah is the smallest, with only 64 Eskimos. These stations carry on a consider- 
able amount of trading, in addition to their work of educating and Christianizing the natives. We made acquaintance with a number of the missionaries, at Hopedale, Nain, Hebron, and Ramah. They live two or three together, with their families, at each place. We found them kindly, earnest, helpful men, who are doing a good work among the Eskimos.

The Hudson's Bay Company maintains a number of posts along the Atlantic coast. We visited but one of them, that at Nachvak. There were but very few Eskimos encamped about the bay-there are only about 80 in all between Ramah and Cape Chidley. George Ford, the agent, has lived at Nachvak with his family since 1877 . He has few visitors. The company's steamer puts in twice a year. Captain Bradford, who maintains a fishing station at Cape Chidley, calls there occasionally, as does also Dr. Grenfell, of the Medical Mission. Visits are usually interchanged with Ramah each winter. But otherwise hardly any one ever comes. Ours was the first schconer that had been there for many years.

White Settlers and Summer Fishermen.-There are comparatively few permanent white settlers on the Atlantic coast, aside from those connected with the above-mentioned posts. The total number in Labrador, from Blanc Sablon, on the shore of the Gulf of St. Lawrence, to Cape Chidley, is given by the Newfoundland census of I891 as 3,106. But of these probably not more than one hundred live north of Hamilton Inlet. We met two as far north as Black Island, near Port Manvers, and none beyond. They support themselves by trapping and fishing. Their rude settlements, composed of a few rough shanties and fishing stages, with possibly a store and a church, are fairly numerous in the south; though 
more often there are only a few scattered houses, or, still further north, entirely isolated homes.

Their character is well depicted by Low (loc. cit., p. $44 \mathrm{~L}$ ), as follows: "In spite of lack of educational advantages, nearly everybody can read and write, and all are very religious. As alcoholic liquors are not openly sold on the Labrador coast, cases of intoxication are exceedingly rare, and many of the younger people do not know the taste of alcohol. On the whole, these people compare favorably with those of more civilized regions, being frugal, moral, willing, good-tempered, and naturally intelligent. Their only fault, want of thrift and providence, is largely due to their mode of living, absence from any market of competitive labor, and the system of credit and debt under which they live."

In the spring and summer this sparse population has a large accession owing to the temporary presence of a host of fishermen from Newfoundland in search of seals or cod. The census of I89I gave their number as over I3,000, including the women and children who go with them. A large proportion of these, however, were on the gulf shore. In the spring time, March and April, they go in large steamers for the capture of seals on the ice; in the summer they are there in their schooners or in rude shelters on the land for cod; and in the early fall they secure herring. Very few of those who go down the Atlantic shore ever get beyond Nain or Port Manvers. One venturesome man alone maintains a fishing station at Cape Chidley all the year round, and goes to it every summer in his steamer. These Newfoundlanders are almost exclusively of English descent, with a queer, oldtime flavor to their speech, with an almost fanatic formal 


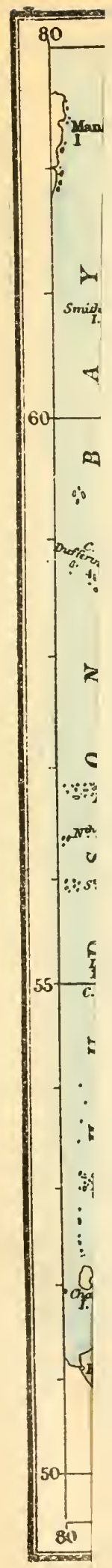





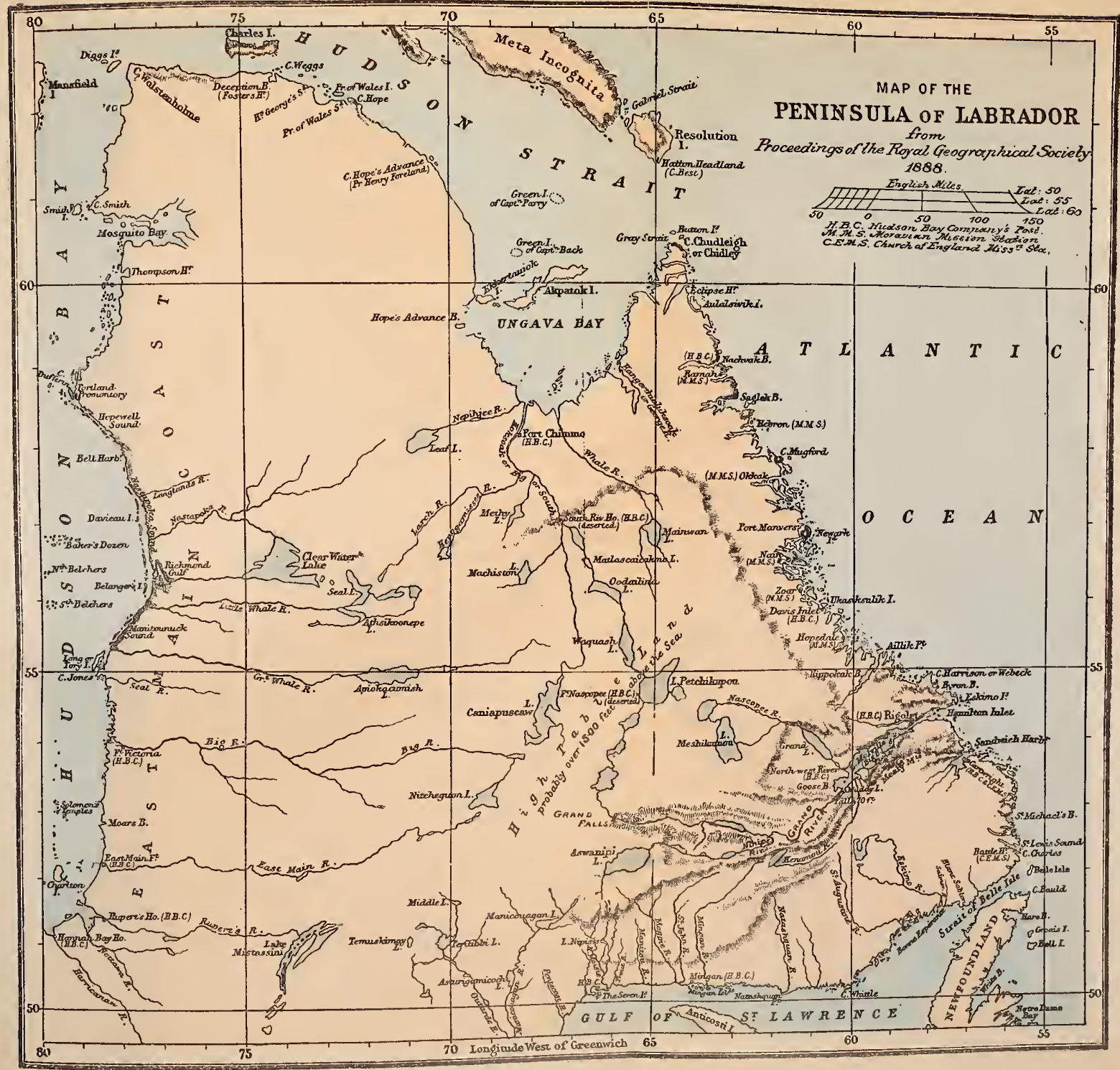


piety and respect for the Sabbath, and with a rather unsavory reputation for wrecking their vessels in order to collect the insurance on them. In the latter respect, however, it is doubtless the few whose misdeeds darken the reputation of the many.

General Conditions of Life.-Along the southern part of the coast these numerous visitors and the regular fortnightly trips of the mail steamer in summer give fairly good communication with the outside world. But both mail and fishermen venture only a part of the way, and those who live farther north see only the rare vessels of the missionaries and of the trading company. The land is too cold and barren to permit any occupations other than those of the hunter, the fisherman, and the trader. The conditions of life are therefore extremely simple, and are naturally in many respects hard and often pitiful. The winters are long and cold, while fuel and food to contend with their severity are scanty and difficult to obtain. The struggle for bare subsistence gives at the best so narrow a margin of surplus that a bad season, or the loss of the supporting members of a family, occasions frequent cases of absolute destitution. Neighbors are few and far away. During the long periods when no work is possible, with little stimulus in the way of books or games, there must be a great dreariness to life; and dreariness usually involves much of moral and intellectual debasement.

Ignorance of hygienic and medical principles leads to a great amount of suffering. Accidents often happen and are always serious. Many a gunshot wound that under proper treatment might have been easily healed has left the only provider for a family a permanent cripple. At least one 
case is known oi a iather chopping off with an ax the legs of his child. because they had become gangrenous as a result of a frost-bite. Wounds, epicemics, and diseases of all tinds are terrible mistortunes. and the loss of life, the blindness and crippling. the suffering and destitution, that result from them are considerabie. Conditions in these respects are improving, howerer, through influences yet to be mentioned.

There is still another uniortunate condition that leads to much hardship. A large proportion of the people are practically slares to the traders. Who charge outrageous prices ior supplies and give small retums for tish and furs. The winter s prowisions are oiten secured only at the price of the next season" entire catch of fish. It naturally iollows that efrort is discouraged. and the people become continually more and more buried in debt. with all the demoralizing consequences of such a concition.*

Thus, aiong with the more attractive phases presented by this pioneer like. there is a large admixture of misiortune and diffculty. A great deal oi the latter is not incapab.e of improvement. and there are several infuences that tend to raise conditions to a betier level. The Moravian Missions and the Hudson's Bay Company are civilizing iorces. But their trading policy is one that increases rather than relieves the debt-slavery. Moreover. these missions are confined to the Estimo. and do not reach the other settlers. The most promising and interesting ieature connected with human existence in Labrador is furnished by the personality of Dr.

* This condition of debt-s'arery and its evil resu'ts are mertioned by sereral observers. Sieazas (Icbrodor, I824) speaks of the credit system as a great source o: misery to the Indians. Compare Low, loc c\%"., p. 42 I. 4 I. 
Grenfell, and the work of the mission of which he is superintendent. This is the Labrador Medical Mission, a branch of the Mission to Deep Sea Fishermen.

The Labrador Medical Mission.--Nothing could be more practical and truly helpful than the way this mission sets to work. It is purely non-sectarian and reaches and is warmly welcomed by Catholics and Protestants alike. Its aim is not primarily the preaching of religion, though strong religious influences of the best sort emanate from it in the most effective way possible, through the example and unselfish helpfulness of its tireless workers. The direct object at which it aims, and toward which it is making large progress, is the uplifting of the people, both native and white, to a higher grade of hygienic, social, economic, intellectual, and moral development.

The first task attempted by this mission was that of providing medical and surgical aid. In this direction it has accomplished a great deal. It has now two hospitals with doctors and nurses on the Labrador coast, one at Battle Harbor and one at Indian Harbor. These are insufficient for all needs, and a third will soon be established. Besides these, a floating hospital is maintained on the "Strathcona,"*

* The following description of this steamer, from the London Graphic of July 27 th, I take from the organ of the Mission to Deep Sea Fishermen, Toilers of the Deep, September, I901, p. 223:-

"The S. S. 'Strathcona' is a steel steamer with sufficient sail area to enable her to be handled without her propeller, being ketch-rigged after the manner of English trawlers. She is eighty-four tons capacity, and is fitted with a hospital amidships. She was designed and built at Dartmouth, England, and came out under her own steam to Newfoundland. Though a small boat for so long a journey, she only took ten and a half days from the Fastnet Light to North Newfoundland, and so economical is she with coal that her deck cargo of coal almost sufficed to cross the Atlantic with, in spite of the heavy westerly winds she had to encounter 
a fine steamer recently given to the mission largely through the generosity of Lord Strathcona, of Canada, who was himself once an agent of the Hudson's Bay Company in Labrador. In this steamer Dr. Grenfell patrols the coast of Newfoundland and Labrador during the summer, carrying aid to all in need of his services, and transporting to the shore hospitals the cases that require it. During the winter navigation is impossible, but the hospitals are kept open and a doctor from them travels by dog sledge about the country. About a thousand cases, counting both in and out patients, have been cared for in the two hospitals each year, and another thousand on the steamer. Last year the number was 8oI on shore and I,072 on the ship, together with 150 by aid of a launch. Numbers like these show how great and indispensable a blessing this service is to fishermen, settlers, and natives.

In another way Dr. Grenfell gives promise of greatly benefiting these people. Realizing their unfortunate slavery to the traders and the unhappy effect of this hopeless loss of

on the passage. She is designed to act under the management of the Royal National Mission to Deep Sea Fishermen as a floating hospital, moving from place to place along the bleak coast of Labrador. No medical man dwells anywhere along that vast coast line, and its scattered people, who amount to several thousand, have no skilled help in accident or illness, except what this boat affords. The 'Strathcona' is admirably adapted for her work. She is fitted with all the necessities for modern surgery, including electric light and a fine X-ray instalment, so that in the frequent accidents that a fishing and hunting life expose the people to they may have the best assistance science can afford. In her first season, last year, over a thousand people sought assistance on board her. The little steamer lies up all winter in the ice, as the sea in these regions freezes over from December to June. A doctor is kept there by the Mission in a small hospital on a central part of the coast, and with his dogs and sleigh he travels from settlement to settlement. The ship has now just refitted and sailed for the coast." 
independence, he is attempting to alter the economic conditions of the coast. For this purpose he establishes cooperative stores with reasonable prices to compete with the extortions of the traders. With flour at \$12 a barrel, pork at $\$ 40$, brown sugar at 20 cents a pound, and other things in proportion, and with low returns for his own produce, the settler cannot be independent. The new stores are cutting these prices to a more reasonable level, and at the same time affording better facilities for disposing of the fish and securing better prices for them. A new industry made possible by the mission is contributing to improvement in the same line. The mission steamer and the hospitals consume much wood as fuel, and wood is needed for buildings and other purposes. This can be prepared to a large extent during the dull season of the fisheries, and thus the industry of the people is fostered and their incomes increased. The mission is now trying at a considerable cost to establish a saw mill, and also to extend the number and success of the stores and provide them with ships of their own for carrying supplies and for transporting fish to the markets.

Besides these good works, Dr. Grenfell is a father to all the orphans of the coast, and relieves all possible cases of need. He distributes books and teaches the people active games. His influence over them is enormous, as a result of his great helpfulness and interest in them. In all these various ways he is improving their social and moral, at the same time with their material, conditions.

To the members of the Brown-Harvard expedition to Labrador last summer, this mission was a revelation as to the possibilities of a wisely-conducted, practical philanthropy. It is undoubtedly the most important and promising feature 
connected with life on the Atlantic side of Newfoundland and Labrador, being an economic and moral force of the greatest significance.

\section{VII. \\ SCIENTIFIC RESULTS OF THE EXPEDITION.}

The points at which we touched on our voyages north and south were so numerous and so close together that they gave us a very thorough idea of the character of the coast we were investigating in its different parts. The structure and appearance of the country vary considerably in different regions; but probably very few of the prominent differences escaped us. We anchored at twenty-eight different places along the seven hundred miles of coast. At almost every one of these places we went ashore, either for a single evening's observations, or often during several days while immediate further progress, for one reason or another, was impossible. We got acquainted also with six localities in Newfoundland in a similar way. At some places we covered a considerable inland territory in our investigations. Thus at St. Lewis Sound we went in a rowboat several miles up one of the rivers; at Aillik several of us took a long walk, extending almost to the head of Mokkovik Bay; at Port Manvers two of the party were encamped for a month; between Hebron and Nachvak two of us covered the entire intervening country on foot; and at Nachvak we made a thorough exploration of the shores, and walked several miles inland to the north.

We were thus enabled to accomplish a very creditable amount of scientific observation along the lines for which we 
were equipped. The work undertaken by Dr. Daly in particular was exceedingly careful and thorough, and his observations contain much that is new and valuable. Our results have not yet been completely worked out, so that it is possible to give of some of them only an incomplete summary. Our very numerous oceanographic data have hardly yet been touched, and the examinations of botanical specimens, especially of the cryptogams, are not yet finished. I shall give in a few brief paragraphs an outline of our results, so far as we know them, and then append the special reports on botany, ornithology, and geology, the two latter by Mr. Bigelow and Dr. Daly respectively. More extended reports will be published later in appropriate places.

(a) Meteorology.-Regular observations were made of air-pressure, humidity, and temperature, of the state of clouds, fog, and sunshine. The results of these observations have already been given in Section II. Their scientific value is unfortunately not large, because of some degree of irregularity in time of observations, of inaccuracy in records, and of inadequacy of apparatus. The regular observations made by the missionaries at some of their stations are of much greater value. These of ours can serve only to give an approximately correct idea of the conditions under which our voyage was made.

(b) Geography.-We made thorough acquaintance with the scenery, structure, topography, and life of probably most of the typical sections of the Atlantic coast. Although all the country we visited is well known to many individuals, and we made no really new discoveries, yet much of it has not found its way into scientific or popular description. We ascended one mountain that probably has never before been 
climbed, and our determination of its height makes of it the most elevated measured height in Labrador. We also named a few hitherto unlabeled mountains. The names that we particularly desire to see retained are these: (I) Mt. Elizabeth; this rises to the height of 2,800 feet, directly behind the Hudson's Bay Company's post at Nachvak, to the north and northwest of it. (2) Mt. Ford (3,900 feet), north and east of the latter. Both of these descend close to the waters of Nachvak Bay, on its northern shore, and are bordered on the west by the Goratsuk* valley. (3) Fall Mountain (3,500 feet); directly north of Mt. Ford, separated from the latter by the Shenukatik $\uparrow$ valley, and marked by a prominent waterfall on its southern face. (4) Mt. Faunce $(4,400$ feet); running off from near the summit of Fall Mountain toward the north, and connected with the latter by a narrow neck. (5) Mt. Eliot (estimated from the summits of Mts. Ford and Faunce as exceeding 5,000 feet); immediately east of Mts. Fall and Faunce, its peak lying in close proximity to that of the latter. (6) Brave Mountain (estimated as 3,700 to 3,800 feet); the highest peak of the group just west of the Bishop's Mitre at Cape Mugford; known sometimes to fishermen as "the Cod-bag." (7) Mt. Packard, the highest peak of the Kiglapait group. (8) The Torngat Mountain Range, a name to be applied to the entire system of mountains extending from Hebron to Cape Chidley.

(c) Photography.-Our photographs of the country and its people are many of them excellent, adding somewhat to accurate knowledge of the appearance of those regions.

\footnotetext{
* Or, Kogârsuk.

$\dagger$ Or, Sennerkitte.

\$The Kaumajet Mountain Group.
} 


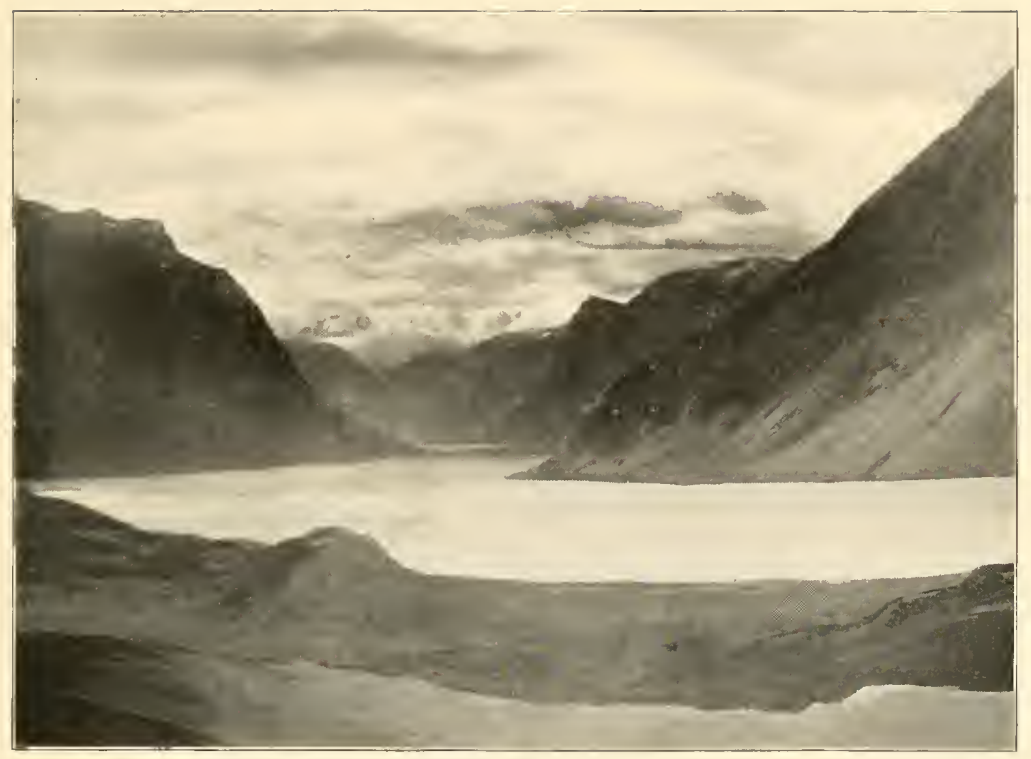

The Tallek; the South Arm of Nachrak Bay.

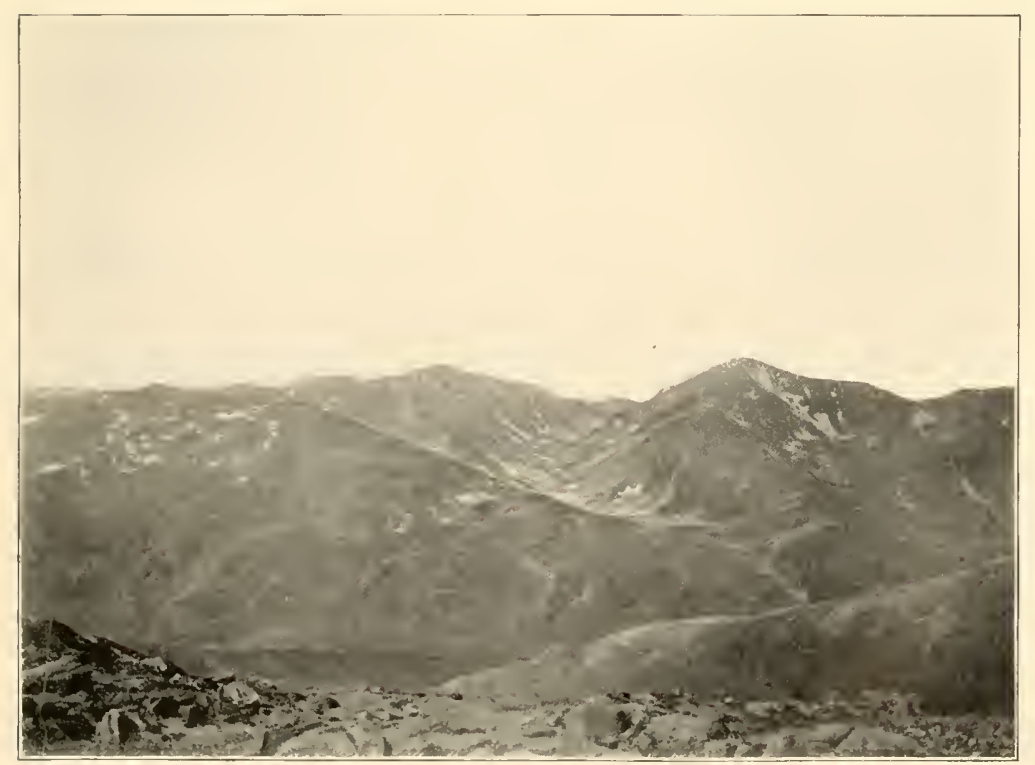

Mounts Fall, Fannce, and Eliot, as seen from the Summit of Mit. Ford. 

(d) Anthropology.-We made no contributions to knowledge in this line, but brought back with us a few articles illustrative of the present and past life of the Eskimos. To the Peabody Museum of Harvard University we presented a large and unusually interesting ancient stone lamp and a pair of fire-stones; and to the Anthropological Museum of Brown University a number of medicine-charms (said by Mr. Ford to have been presented to him by an Eskimo chief, Idualuk, from Akpatok Island, who at one time practiced cannibalism), and of grave relics, the latter including ancient stone lamps, cooking pots, knives and scraping tools, bird-darts, harpoon points, etc. The firestones are of a type new to us. They are two small, round stones of soft material, in which are embedded great numbers of minute fragments of iron pyrites. In use, according to Mr. Townley, the missionary at Hebron, who gave them to us, these stones are knocked together rapidly over a quantity of the cotton from a plant common in that country (Eriophorum, of which there are several species). Fine particles, warmed by the knocking process, fall from the stones into the cotton, which is then rubbed and blown into a blaze.

(e) Psychology.-While our stay was too short and our acquaintance with the people of the coast too superficial to permit of the gathering of any new facts of value in regard to their character and mental habits, yet from observation and conversation we gained a fairly good impression of the general nature and conditions of life there; and I have endeavored to give expression to this impression in the preceding section.

(f) Entomology.-There was no one in our party 
fitted to make studies in this line; consequently, we collected but very few specimens. One among them, however, turned out to be of interest. Dr. Packard reports upon it as follows: *

"Last summer, Prof. E. B. Delabarre, during his expedition to Northern Labrador, observed and collected some locusts, and kindly presented me with three specimens. One is from Nachvak, collected at a point two miles inland from the harbor, and two others at Cape Mugford, directly on the coast, at a point 300 to 400 feet above the level of the sea. The locusts were common locally, in spots. Dr. Scudder has kindly identified them as Melanoplus extremus junius. This is its first occurrence in the Labrador peninsula, the species occurring throughout British America and on the summit of Mt. Washington, N. H."

(g) Botany.-Botanical collections were made in a great many localities, and many records were made of the growth in localities whose varieties were not fully collected. Though the writer can lay no claim to skill in this science, yet it was possible for him to identify a large number of the more common plants; and whenever there was any doubt, specimens were preserved. The plants of this collection have been submitted to various authorities for determination. A list of them, containing very nearly three hundred names, to which the unexamined mosses are yet to be added, is given in the next section. Most of these have been reported previously as occurring in Labrador. A considerable addition is made by us, however, to the list of definite localities; and over twenty species of phenogamous

* "Occurrence of Melanoplus extremus in Northern Labrador." By A. S. Packard, Psyche, April I90I, p. I9I. 
plants are now reported for the first time from the Labrador coast. One of the latter has never before been known east of Manitoba; four are reported by us further north and one further south than their previously-announced limits; nine are new to the coast, but have been found previously in other parts of the Labrador peninsula; while two others have been reported thus far only vaguely from the "coast," without definite locality. Of plants previously recorded from definite localities, two have their known limits now extended somewhat to the north, and one to the south; while nearly fifty have been reported previously by a single anthority only, and are now confirmed. Of the mosses, nine are new to the Labrador peninsula, and eleven are now first given definite locality on the coast; while nearly half the specimens are yet to be examined. Seven new hepatics are named, three of them, as yet, doubtfully. Five lichens are new to the country. Of the fungi, all, so far as can be determined from the authorities consulted, are new. For greater detail concerning these matters, reference must be made to the following section.

(h) Ornithology.-Henry W. Bigelow kept a careful list of all the birds he saw, and of the localities where they occurred. His month on shore at Port Manvers made possible an exhaustive study of that locality. None of his birds are new, but several are rare on the Labrador coast. His report will be found in Section IX.*

(i) Economic Mineralogy.-Adams and McCornick gave particular attention to the search for mineral deposits

* A still later report by Mr. Bigelow, identical in its list of birds with the one given in Section IX, will be found in $A u k$, 1902, Vol. XXVII, pp. 24-3I. 
of economic value. Most of their results in this line were of a negative nature. Probably the great mass of the country would not repay further investigation. It contains large quantities of iron ore, some copper, some mica, and some asbestos. It is not probable that any of these could be worked to advantage. Our conclusion was that the only localities that would be worth prospecting further are the vicinity of Nain, and some 300 square miles about Mugford and Nachvak. In the former place precious labradorite occurs, doubtless in other situations than those already discovered. In the latter region the structure of the country is such as to admit the possibility of other valuable finds. Pure graphite has been discovered about Nachvak Bay (see Daly, Geology of the Northeast Coast of Labrador, p. 234).

(j) Ocennography.-Dr. Daly made studies of the Labrador current; sounded and charted Nachvak Bay, finding it a typical fiord, I Io fathoms at the deepest part, and, therefore, the deepest measured bay in Labrador; and made almost daily observations of the temperature and salinity of the sea-water at different depths. Among his results were the determination of a temperature of $29.6^{\circ} \mathrm{F}$. at the bottom of the Straits of Belle Isle, and of $29^{\circ} \mathrm{F}$. in the depths of Nachvak Bay. These studies were carefully made and will be valuable; but their results have not yet been suffciently computed for any report upon them at present. Besides their value as mere oceanographic data, they also furnish material to some extent for study of conditions of life among the cod, a matter of practical importance in which Dr. Daly was largely interested.

(k) Geology.-Dr. Daly was a tireless worker in this field. He devoted attention to many different lines of study, 
and made discoveries that will form large contributions to geological knowledge of Labrador. Among the many special subjects which he investigated were the following:*

(I) Phenomena of former submergence and subsequent uplift of the coast. This has occurred since the glacial epoch, and not to the same extent on different parts of the coast. There is a maximum of uplift in the vicinity of Hopedale (390 feet), whence its amount diminishes steadily toward the north, being 250 feet at Nachvak, and toward the south to a minimum about Hamilton Inlet (26o feet). From the latter it again increases southward to another maximum in Newfoundland, attaining 575 feet at St. John's. The determination of these facts has involved:

First, a study of raised beaches and other elevated results of the former contact of land and sea. The heights of a great many of these were measured, and an attempt to correlate them led to the opinion that they were not formed at corresponding heights in the different localities by relatively long pauses in the process of uplift, as has been surmised; but that their particular heights are due to local conditions of exposure and rock-resistance, and need not correspond in height in the different localities.

Second, the discovery of a criterion for determining the upper limit of former stumergence. This was found in the boundary between the boulder-strewn upper and the boulder-free lower zone, the former having evidently never

* This outline was given to me by Dr. Daly immediately after our return from Labrador, and is subject to any corrections that may appear in his own account of his results. These have now been given in his "Geology of the Northeast Coast of Labrador," Bulletin of the Museum of Comparative Zoölogy at Harvard College, Vol. XXXVIII, February, I892, pp. 205-270. 
been subjected to sea-action since the boulders were deposited during the glacial epoch. This criterion was independently discovered by Dr. Daly, though he finds that it is not the first time that it has been used.

Third, the measurement of the upper limit of submergence. This was accomplished at almost all the localities we visited, with the results outlined above.

(2) Phenomena of glaciation. In this field many new discoveries were made, including:

First, large numbers of heretofore unobserved glacial striæ and grooves.

Second, a considerable number of terminal and lateral moraines, whose existence in Labrador had been doubted.

Third, an upper limit to the extent of general glaciation among the higher mountains of the north. Above 2, Ioo feet there are no traces of alteration by the ice-sheet.

Fourth, numerous new localities where lunoid markings occur, and an adequate theory of their origin, together with definite proof of their connection with the movements of the ice in the glacial epoch.

Fifth, a great many fine examples of hanging valleys in the vicinity of Nachvak-an effect of glacial action not previously known to exist in Labrador.

Sixth, the determination of the direction of movement of the main ice-sheet in the different localities; and evidence that in the vicinity of Nachvak the glaciers followed the trend of the local valleys, not covering the tops of the mountains.

(3) The discovery of sedimentary rocks in localities where none had been known previously; as, for example, the breccias of Pomiadluk Point and the broad region of slate, sandstone, and conglomerate on either side of Ramah. 
(4) A collection for further study of all the eruptive rocks found on the coast. These include also specimens of the unique volcanic bombs occurring at Kirpon in Newfoundland.

(5) An interpretation of the scenery, with reference to:

First, rock-structure; this included the determination of the strike-lines of the rocks, resulting in the discovery that the coast-line follows the strike on the Atlantic border, and thus corroborating the theory that Labrador has nothing to do with the Appalachian system.

Second, submergence in its effects on a glaciated landscape.

Dr. Daly himself reports on these matters in greater detail in Section X.

\section{VIII. \\ REPORT ON BOTANY.}

Vegetation in Labrador pushes up in great abundance with the first disappearance of the snows. Throughout the summer and early autumn all the country is thickly covered with vigorous plant life and adorned with a great multitude of flowers from which it gains a large variety in coloring. Only where snow-drifts linger, or where bare rock masses protrude, or on the higher slopes and summits, are these growths absent. Near the coast the growth is never high. Extensive evergreen forests exist in the interior, even as far north as the latitude of Nachvak, according to George Ford of that place. But in the mountainous region bordering on the sea trees grow only in sheltered nooks and valleys, and 
rarely in large groups except fairly well in from the coast.* We found, for instance, spruces growing to Io feet in height a little way up the St. Charles River, and it is reported that far up St. Lewis Inlet they are large enough for ship-timber. In the ravines on the shore of Aillik Bay and in a low, flat valley at its head, we noticed considerable groups of trees, including willows ro feet and spruce 30 feet high. Still further inland, along the shores and near the head of Mokkovik Bay, there were somewhat extensive thick groves in which spruce attained the height of perhaps 50 feet. Back of the mission station at Hopedale is a large grove of larch; and at Nain another of various evergreens. These were the only places where we encountered trees of any size. Elsewhere we found only scattered, stunted trees, or scrub growths that were very rarely thick enough to cause any difficulty in walking. Black and white spruce, dwarf birch, and various willows were the most common forms, with larch, juniper, balsam fir, and alder also occurring. Hebron is, apparently, the northern limit of evergreens near the coast, for north of it we saw none of them at all, even on our walk a considerable distance inland. Alder, birch, and willows still grew vigorously, the latter attaining the height of seven or eight feet in moist hollows near Nachvak Bay.

The great mass of the vegetation of Labrador consists of low forms. It grows so thickly and vigorously in the thin soil, however, that the country never gives the inpression of being lifeless and barren. In the far south, especially on moist lowlands, Sphagnum is often a prevailing growth. But aside from its rather rare supremacy, al-

* See Low, Annual Report, Geol. Surv. Can., VIII, 3I L; quoted in full in Section $V$ of this report. 


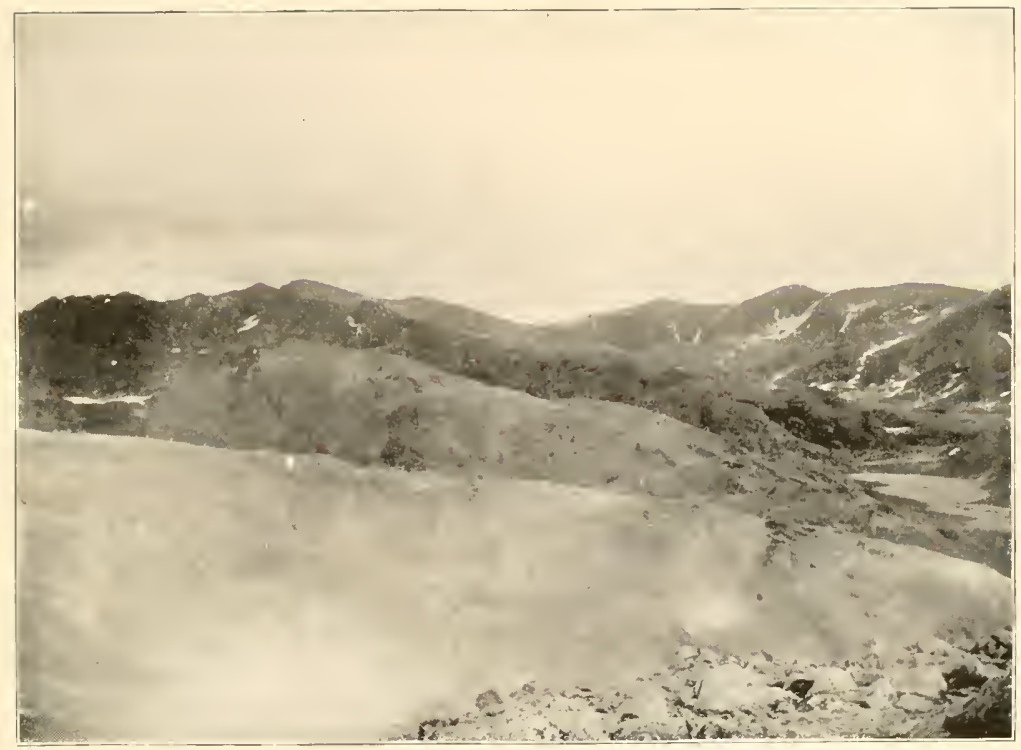

Vicw to the Southeast from the Summit of Mt. Faunce.

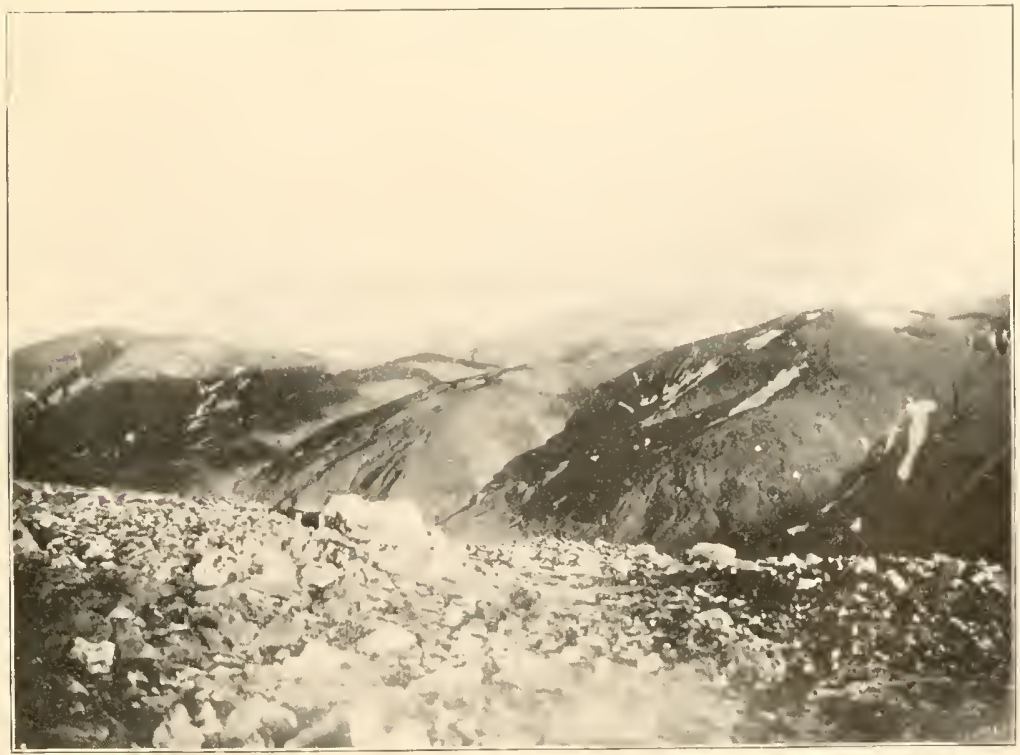

Tiew to the South from the Sumnit of Mt. Faunce, 

most everywhere we went we found the curlew-berry (Empetrum nigrum) and the so-called caribou-moss (Cladonia, really a white lichen) together forming an almost continuous green and gray sward, touched with red in the autumn. The berries of the curlew are exceedingly numerous, and those of the previous season still cling thickly to the vine among the green new ones, and even until the latter begin to ripen in the middle of August. In the midst of this continuous curlew and moss grow occasional clumps of grasses of many kinds, and a great variety of flowering plants. Perhaps the most common of the latter are the Ericacce. Some of them are berry-bearing, with inconspicuous flowers, particularly the blueberry (Vaccinium Pemsylvanicum and $V$. uliginosum), the mountain cranberry (V. Vitis-Idca), and the bearberry (Arctostapliylos alpina). Others have more prominent flowers, such as the omnipresent Labrador tea (Ledum), together with the somewhat less universal Loiseleuria and Bryanthus. These are all exceedingly abundant in the southern half of the peninsula, but extend variously far to the north. The white clusters of the Ledum and the purple umbels of the Bryanthus are very conspicuous. In the autumn, the red-turning leaves of the Arctostaphylos are the most attractive of the season's colorings. There is also a large number of other plants that are constantly met with, though few of them are so nearly omnipresent and continuous as are most of those already mentioned. The bakeapple or cloudberry (Rubus Chancemorus) grows thickly as far north as Hebron, but very thinly beyond. We could find but very few of its ripe berries in Labrador, though in Newfoundland they seem to be common. Associated with its single white flowers are frequently seen the showy, rose- 
colored ones of the arctic raspberry (Rubus arcticus). This also, so far as our experience could determine, had about the same limits and was equally rare in fruit. Bunchberry (Cormus Canadensis) is likewise very common, especially in the south, and grows in thick groups. Dense tufts of the white-flowered Diapensia Lapponica and of the beautiful moss-like pink Silene acaulis greet the eye continually. Astragalus and Oxytropis, Dryas, a great variety of saxifrages, Sedum, Pedicularis, the violet-like Pinguicula, and many inconspicuous Cruciferce and Caryophyllacea complete the list of forms more universally present in the early part of the season.

After the beginning of August, when we had reached a higher latitude, the character of the vegetation changed considerably. Caribou moss, curlew-berry, blueberry, and Arctostaphylos still remained the most continuous growths. But the flowers began to change to more autumnal forms. The arctic golden-rod (Solidago Virga-aurea and S. macrophylla) appeared abundantly. The large, showy pink flowers of the Epilobium and the thick pink heads of Lychnis were very prominent. Yellow Arnica alpina and delicate blue harebells (Campanula) were common. A yellow poppy (Papaver nudicaule) with early deciduous petals was not infrequent on the hill-tops. A strikingly beautiful flower, though a rare one, was the small twin-flower (Linnca borealis). Fungi, including Boleti, Russulc, and various agarics, also become very abundant toward the close of the summer; they were fairly numerous in the north, and the moist woods about Nain and Hopedale were full of them.

Along the shore, in addition to many of the above varieties, several other plants were of very frequent occur- 
rence. Seaside sandwort (Arenaria peploides), sea-lungwort or ice-plant (Mertensia maritima), Potentilla anserina and tridentata, two large Umbelliferce (Archangelica and Colopleurum), and one or two species of plantain (Plantago) we found almost everywhere, even to the far north, though only one or two of them occurred quite as far as Nachvak; while iris and beach-pea (Lathyrus maritimus) were also very abundant, but were confined to much more southerly limits.

The thoroughness of our examination of the coast was favorable to a fairly exhaustive study of the Labrador flora. This feature was offset, however, to a certain extent by my own inexpertness in the botanical field; and for this reason it is probable that many interesting plants escaped my notice. Of the more common and easily recognized varieties I preserved no specimens, because of the difficulty of making and caring for a large collection in our limited quarters. In almost all cases of doubt, however, and in many cases where there was none, I brought home specimens for identification. The names given on my own authority alone are comparatively few, and are with few exceptions those of plants in regard to which there can be little or no uncertainty.

The largest part of the credit for the list which I am able to present is due to those on whom has fallen the work of identification of specimens. Prof. W. W. Bailey, of Brown University, undertook the examination of all the phenogamous plants, with the exception of the willows; and his careful work has been further revised by Prof. B. L. Robinson and Mr. M. L. Fernald, of Harvard University, of whose kindly and able assistance we wish to make grateful acknowledgment. The willows were named by Prof. W. W. Rowlee, of Cornell University. The mosses were submit- 
ted to Mr. J. F. Collins, of Brown University, who is able, as yet, to report on only a portion of them; these, however, are the only portions of my collection in regard to which this report is incomplete. The lichens have been examined and identified by Professor Clara E. Cummings, of Wellesley College. Unfortunately, a large portion of the fungi collected were imperfectly preserved and could not be named. The list of them here given represents, therefore, very inadequately their actual variety in Labrador. I am indebted to Prof. W. G. Farlow, of Harvard University, for their names. To all of these men I wish to express my sincere appreciation of their interest and help.

For a knowledge of the localities from which the various species of phenogamous plants here enumerated have been reported previously, I have consulted the following authorities:

(I) Robert Bell: "Observations on the Geology, Mineralogy, Zoölogy, and Botany of the Labrador Coast, Hudson's Strait and Bay." Geol. and Nat. Hist. Surv. of Can., Report of Progress, DD, I884. To this are added two names given in a similar report the following year.

Bell's list, the plants of which were identified by Prof. J. M. Macoun, contains seven columns, of which only three apply to Labrador proper. His columns 4 (Cape Chidley) and 5 (Nachvak, Ford's Harbor, and Nain) are the only ones here considered, column 6 containing only species in the collection of Weiz, more fully reported by Packard.

(2) A. S. Packard: The Labrador Coast. New York, I89I.

Prof. Packard's list aims to enumerate all the localities reported by all previous observers. The list was rompiled by Prof. Macoun. 
(3) Henry G. Bryant: "A Journey to the Grand Falls of Labrador." Geog. Club, Phila., Bulletin No. 2, March, I894.

(4) A. P. Low: "Explorations in the Labrador Peninsula." Geolog. Surv. Can., Part L, Annual Report, Vol. VIII, I896.

The list here given was compiled by Prof. Macoun. It contains four columns, of which only the first applies to the coast of Labrador, and includes all previous reports from that region, but without definite mention of locality. His other three columns include only plants found further west, in the interior, and for the most part in portions of the peninsula now included in Quebec and not in Labrador proper.

(5) A. C. Waghorne: The Flora of Nerufoundland, Labrador, and St. Pierre et Miquelon. St. John's, I893, I895, I898.

This list aims to bring up to its final date all previous local references, but includes only phenogamous plants as far as Plantaginacex in Gray's order of families.

(6) M. L. Fernald and J. D. Sornborger: "Some Recent Additions to the Labrador Flora." Reprinted from The Ottawa Naturalist, Vol. XIII, July, I899.

(7) John Macoun: Catalogue of Canadian Plants. I $883-92$.

In regard to all species not previously reported from Labrador, or in case of which I find only one or two previous local references, I have consulted Britton and Brown's Illustrated Flora of the Northern States and Canada (New York, 1896-98), and Gray's Synoptical Flora of North America, so far as it is yet completed. I count as not previously reported even those stated by these authorities 
as occurring in Labrador, inasmuch as many so reported were observed in Canadian portions of the Labrador peninsula, unless in the above lists they are given definite locality within the limits of Labrador proper as these limits are now defined, i.e., from Blanc Sablon north to latitude $52^{\circ}$, thence along the height of land to a point on Ungava Bay, a little south of Cape Chidley, and thence following the coast around the latter back to Blanc Sablon.

None of the fungi here definitely or approximately named have been previously reported in the above-named lists. Of the mosses, eleven are new to the Labrador coast, and five others have been reported heretofore from one locality only. All seven of the hepatics here named are now reported for the first time, although three of these names can be given as yet only provisionally. Five of the lichens are apparently new to Labrador.

Among the phenogamous plants there is a considerable number that are of especial interest. Twenty-three of them are new to the Labrador coast. Two of these (Pyrola chlorantha and Salix uva-ursi) have been reported already indefinitely from the "coast," but this may refer sometimes to that part of the coast that belongs to Quebec. Nine are new to the coast, but have been found previously in other parts of the Labrador peninsula. These are: Oxytropis podocarpa, Saxifraga Hirculus, Gentiana propinqua, Abies balsamea, Juncus castaneus, Luzula hyperborea, Eriophorum alpinum, Catebrosa aquatica, Poa nemoralis. Six others also are new under names here given, but may probably have been reported before under the name of another species or variety, namely: Stellaria humifusa var. ovalifolia, Epilobium angustifolium forma stenophylla, Colopleurum actcifolium, 
Pyrola rotundifolia, Salix Gronlandica, Salix Labradorica. Six are entirely new to Labrador; one of them (Carex filifolia) has never been known east of Manitoba; one (Carex compacta) now appears southward of its usual limits, Greenland and Arctic America; four (Dicentra Canadcnsis, Polygonum littorale, Festuca rubra, Lycopodium lucidulum) are now extended to the north of their previous limits.

Of those which were already known on the Labrador coast, a few appear in localities considerably beyond the ones where they have been found before. Thus, for Poa alpina, Cape Chidley or Nain was previously the southern limit, but it is now found on Hare Island, almost in the extreme south; while two (Calmagrostis Canadcnsis, Hierochloe borealis), which were before unknown north of Hamilton Inlet or Hopedale, are now found as far north as Port Manvers or Nachvak. Besides these, there are among the phenogamous plants about fifty that have been reported previously only from a singe locality, or by a single authority.

In all, about 500 specimens are included in the collection. These have yielded the list given below, which includes not far from 300 names, of which 45 are from identifications made by myself alone, unconfirmed by specimens preserved. The latter will be easily detected in the list from the lack of numbers referring to specimens, and cannot be considered so authoritative as the others.

In the list that follows, an asterisk (*) preceding a name means that the plant has not been previously definitely reported from the Labrador coast; a dagger $(\dagger)$ means that it has been previously reported only from a single locality or by a single authority.

In the local references, first are given the localities of all 
the specimens in my collection, following the number of the specimen. Most of these references are from definite localities; a few are recorded merely as from Southern Labrador, and of these the majority were collected in the vicinity of St. Lewis Sound or of Seal Islands. Such terms as "HebronNachvak" mean that the plant occurs at one or the other, or between, the two places. Specimens from Mt. Faunce were collected between 3,500 and 4,400 feet above sea-level at our most northern point. After the initials E. B. D. are given the localities where the plant occurs according to my own observation, unsupported by collected specimens. Finally, after the word "Previously," come former references, the authorities being abbreviated as follows: B :, Bryant; all these are from the basin of the Grand or Hamilton River. BM :, Macoun's list in columns 4 and 5 of Bell's report. F:, Fernald and Sornborger. L:, Macoun's list in column $\mathrm{I}$ of Low's report. M :, Macoun's catalogue. P:, Macoun's list in Packard. W :, Waghorne. Later references to the same locality are not given when taken from an earlier source; and references merely to the "coast of Labrador" or to "Labrador" are rarely given when definite localities can be named, because it is often uncertain whether those terms refer to Labrador proper.

The dates of collection or observation of the plants, together with the comparative position of the stations, can be determined by reference to the list of stations given in Section II.

No attempt is made to enumerate all Labrador plants, the list being confined to those observed or collected on this expedition. 


\section{A. PHENOGAMOUS PLANTS.}

Ranunculaceæ :

Coptis trifolia, Salisb. (Goldthread). E. B. D.: Great Caribou Island, Rodney Mundy Island, Jigger Island, Ford Harbor. Previously: W: Forteau (Butler); Battle Harbor and other places.

$\dagger$ Ranunculus hyperboreus, Rottb. (Northern Crowfoot). (142) Hopedale. Previously : W: Cape Chidley (Cat. III, 480); doubtful specimen from Pack's Harbor. E. B. D.: This plant is well-known at Hopedale, but was called R. pygmæus by Dr. Hettasch there.

Ranunculus nivalis, L. (55) Hebron-Nachvak. Previously: P. Hopedale (Weiz). BM: Cape Chidley.

$\dagger$ Ranunculus pygmæus, Wahl. (53) Hebron-Nachvak; (25) Mt. Faunce. F. B. D.: Cape Mugford. Previously: BM: Cape Chidley; attributed to Hopedale by Packard (Weiz), but this is probably the $\mathbf{R}$. hyperboreus above. P: Coast of Lab. (Pursh).

Papaveraceæ :

Papaver nudicaule, L. (Arctic Poppy). (90) Port Manvers; (35) Nachvak. F. B.D.: Hebron-Nachvak. Previously: P: Hopedale Islands (Weiz); BM: Cape Chidley.

Papaver sp. (23) Mt. Faunce.

\section{Fumariaceæ :}

*Dicentra Canadensis, DC. (Squirrel Corn). (295) St. Charles River. No previous record of any Fumariaceæ. This specimen has the leaves only.

\section{Cruciferæ :}

Arabis alpina, L. (Mountain Cress). (80a) Port Manvers or Mugford; (78) Mugford; (52) Hebron-Nachvak. Previously: BM: Cape Chidley. P: Coast of Labrador (Kohlmeister); Forteau (Butler); Hopedale Islands (Weiz). W: Battle Harbor.

Cardamine pratensis, L. (Cuckoo Flower, Ladies' Smock). (56) Hebron-Nachvak. Previously: BM: Cape Chidley. P: Hopedale (Weiz).

Cochlearia sp. (50) Hebron-Nachvak.

The species of Cochlearia are almost impossible to determine. Several are reported from Labrador, two by Packard (Weiz) from Hopedale, all others from south of Hamilton Inlet.

†Draba aurea, Vahl. (93, 94) Port Manvers. Previously: P: Hopedale (Weiz).

Draba incana, L. (Whitlow-grass). (186) Southern Labrador; (250) Pottle's Cove; (150) Rodney Mundy Island; (22) Mt. Faunce. E. B. D. : Pomiadluk. Previously: P: Coast of Lab. (Pursh); Hopedale (Weiz); Nachvak (Bell). W: Battle Harbor, Snack Cove, 
Square Islands, L'anse au Clair. Some of these references apply to var. confusa, Poir.

†Draba nivalis, Lilj. (fide B. L. R.) (43) Hebron-Ramah. Previously: F: Cape Chidley, Okkak.

Draba sp. (161) Rodney Mundy Island.

\section{Violaceæ :}

Viola blanda, Willd. (White Violet). E. B. D.: Aillik-Mokkovik. Previously: P: Hopedale (Weiz). W: Battle Harbor.

Viola canina, L., var.? E. B. D.: Mosquito Bight, common; Ford Harbor. Previously: BM: Nachvak-Nain. P: Hopedale (Weiz). W: Forteau (Butler); Sandwich Bay (Shears).

\section{Caryophyllaceæ:}

Arenaria Grœnlandica, Spreng. (Greenland Sandwort). (153) Pomiadluk; (123) Ford Harbor. E. B. D.: Hebron-Saglek (probably). Previously: BM: Nachvak-Nain. P: Hopedale (Weiz). W: Sandwich Bay (Shears); Venison Tickle.

Arenaria peploides, L. (Seaside Sandwort). (220) Southern Labrador. E. B. D.: Common on the shore everywhere, as far north at least as Hebron; specially noted at Great Caribou Island, Pottle's Cove, Jigger Island, Aillik and Mokkovik, Ford Harbor, Iterungnek. Previously: P: Hopedale (Weiz). W: Forteau (Butler); Seal Islands, Snack Cove, Turner's Head.

$\dagger$ Arenaria Sajanensis, Willd. (33) Nachvak. Previously: W : Cape Chidley (C. H. Geo. S. Can., V. 5) .

Cerastium alpinum, L. (Mouse-ear Chickweed). (188) Southern Lab.; (249) Pottle's Cove; (177) Rodney Mundy Island; (14) Nachvak; (21) Mt. Faunce. E. B. D.: Common; noted also at Aillik Bay, Ford Harbor, Iterungnek, Saglek. Previously: BM : NachvakNain. P : Hopedale Island (Weiz) ; Forteau (Butler). W : Sandwich Bay (Shears) ; Battle Harbor. M : Ford's Harbor, Cape Chidley (Bell).

Lyehnis alpina, L. (88) Port Manvers; (62) Hebron-Nachvak. E. B. D.: Iterungnek, Ramah-Nachvak, Nachvak. Previously: BM : Nachvak-Nain: P : Coast of Lab. (Morrison) ; Hopedale (Weiz). W: Snack Cove.

Lychnis apetala, L. (47) Ramah. Previously: BM : Cape Chidley. P : Coast of Lab. (Morrison).

† Sagina procumbens, L. ? (178) Rodney Mundy Island ; (117) Ford Harbor. Previously: F: Hebron.

Silene acaulis, L. (Moss Campion) (191) Southern Lab.; (246) Pottle's Cove. E. B. D. : Common throughout the region; specially noted at Great Caribou Island, Seal Island, Rodney Mundy Island, Ford Harbor, Saglek Bay. Previously: BM: Cape Chidley, NachvakNain. P: Hopedale (Weiz). W: Battle Harbor, L'anse au Loup. 
Stellaria borealis, Bigel. (Northern Stitchwort). (304) St. Charles River; (156) Jigger Island. Previously: P: Hopedale (Weiz). W: Battle Harbor, Venison Tickle.

Stellaria humifusa, Rottb. (219) Southern Lab.; (156a) Jigger Island; (51, 54a) Hebron-Nachvak. E. B. D. : Great Caribou Island, Rodney Mundy Island; Iterungnek? Previously: BM: Nachvak-Nain. P: Hopedale (Weiz); Seashore Lab. (Pursh). W: Battle Harbor and several places along the coast.

* Stellaria humifusa, Rottb. var. ovalifolia, Fenzl. A specimen; so named by Mr. Collins, was found by him among the mosses given him for identification. Its exact locality cannot be given.

Stellaria longipes, Goldie. (247, 257) Pottle's Cove, (120) Ford Harbor. E. B. D.: Jigger Island. Previously: W: Battle Harbor (Bull); Sandwich Bay (Shears); Pack's Harbor, L'anse au Loup. Several varieties are given by various authorities, with localities extending to the extreme north.

\section{Portulacaceæ:}

Montia fontana, L. (Water Blinks or Chickweed). (54) HebronNachvak. Previously: P: Coast of Lab. (Gmelin). W: Battle Harbor, Emily Harbor, Cape Charles, Seal Islands, Pack's Harbor.

\section{Leguminosæ:}

Astragalus alpinus, L. (Milk-vetch). (209, 210) Southern Labrador; (258) Pottle's Cove; (7) Nachvak. All of these specimens consist of leaves only, and are named with some doubt. They are unquestionably, however, identical with what has been thus identified previously. E. B. D.: Exceedingly common at all stations throughout the entire coast region. Previously: BM: Cape Chidley, Nachvak-Nain. P: Forteau (Butler); Hopedale (Weiz). W: Battle Harbor, Sandwich Bay.

Lathyrus maritimus, Bigelow. (Everlasting Pea, Beach Pea). (206, 241) Southern Lab.; (254) ? Pottle's Cove. E. B. D.: Great Caribou Island, Jigger Island. Previously: P: Hopedale (Weiz). W: Battle Harbor, St. Michael's and other places.

Oxytropis campestris, DC., var. cœrulea, Koch. (fide B. L. R.). (175) Rodney Mundy Island. E. B. D.: This, or something similar, at Brig Harbor Island, Ford Harbor, Iterungnek-Saglek. Previously: BM: Cape Chidley, Nachvak-Nain. P: Forteau (Butler); Hopedale (Weiz); Square Island (Allen). W: Battle Harbor, Sandwich Bay, Grosswater Bay.

* Oxytropis podocarpa, Gray. (49) Hebron-Nachvak. No definite previous reference. P. speaks of it as in the Herb. Gray; M, refers it to "Labrador" on the authority of Gray.

Rosaceæ:

Alchemilla vulgaris, L. (Lady's Mantle). (195) Southern Lab.; 
(77) Mugford. Previously: P: Hopedale (Weiz). W: Battle Harbor, L'anse au Loup, Blanc Sablon.

Amelanchier Canadensis, var. oligocarpa, T. \& G. (Shad-Bush, Juneberry, Indian Pear). F. B. D.: Great Caribou Island, AillikMokkovik. Previously: W : Deep Water Creek, Pack's Harbor. Low speaks of its occurrence in the interior northward to Big and Hamilton Rivers.

Comarum palustre, L.? (Potentilla palustris, Scop.). (181) Rodney Mundy Island. F. B. D.: Saglek Bay? Previously : P: Hopedale (Weiz). W: not uncommon along the coast of Southern Lab.

Dryas octopetala, L., probably var. integrifolia, C. \& S. (199) Southern Lab.: (72) Mugford; (15) Nachvak. E. B. D.: Port Manvers, Iterungnek-Saglek. Previously: BM: Cape Chidley, Nachvak-Nain. P: Hopedale (Weiz); Point Amour (Butler). W: Battle Harbor. F: Ramah.

Potentilla anserina, L. (Silverweed). (205) Southern Lab. E. B. D. : Great Caribou Island, Jigger Island, Aillik-Mokkovik, Ford Harbor and vicinity, Saglek Bay. Abundant on the shore. Previously: BM: Nachvak-Nain. P: Hopedale (Weiz). W: Battle Harbor and other places.

†Potentilla nivea, L. (147) Pomiadluk. Previously: P: Hopedale (Weiz). M: Labrador (Hooker).

Potentilla rubens, Vill. (P. maculata, Poir.) (244) Pottle's Cove. E. B. D.: Iterungnek-Saglek? Previously: BM: Nachvak-Nain. P: Hopedale (Weiz). W: Long Point. M: Cape Chidley (Bell).

Potentilla trideptata, Ait. (Three-toothed Cinquefoil). E. B. D.: Rodney Mundy Island, Jigger Island, Ford Harbor, Iterungnek. Previously: BM: Nachvak-Nain. P: Hopedale (Weiz). W: Many places on the Labrador.

Pyrus Americana, DC., var. (American Mountain Ash). E. B. D.: Great Caribou Island, Aillik Bay. Previously: P: var. microcarpa, Hopedale (Weiz).

Rubus arcticus, L. (Arctic Raspberry. Dewberry, Eye-berry). (190) Southern Lab.; (259) Pottle's Cove; (141) Hopedale; (119) Ford Harbor. E. B.D.: Common at least as far north as Hebron. Specially noted at Rodney Mundy Island, Jigger Island, Aillik-Mokkovik, Iterungnek. Number of petals very variable, from 4 to 8 , usually 6 . Apparently rarely fertile, none of its fruit being found by us. Previously: This or var. grandiflorus: BM: Nachvak Nain. P: Hopedale (Weiz). W: Straits of Belle Isle, Indian Harbor, Holton.

Rubus Chamæmorus, L. (Bake-apple, Cloud-berry). (192, 203) Southern Lab.; (217) St. Lewis Sound, Seal Islands. E. B. D.: Very common at all stations as far north as Hebron; rare beyond. Petals and calyx-lobes very variable, from 4 to 6 . Apparently rarely fertile. 
Previously: BM: Nachvak-Nain. P: Straits of Belle Isle (St. Cyr); Hopedale (Weiz). W: very common (Macoun). Low: in the swamps everywhere throughout Labrador to beyond the tree limit. M: abundant in Labrador, etc. (Fowler's Cat.).

Rubus strigosus, Michx. (Red Raspberry). E. B. D.: Aillik-Mokkovik; Port Manvers? Previously: W: frequent in many places from the Straits to Hamilton Inlet. F: Mallijak in Hamilton Inlet.

Rubus triflorus, Richardson. (Dewberry, Eye-berry, Plumboy). E. B. D.: Rodney Mundy Island? Aillik-Mokkovik? Previously: P: Forteau (Butler). W: Capstan Island and several places in the Straits and northward.

Rubus sp. (149) Rodney Mundy Island.

Sibbaldia procumbens, L. (260) Pottle's Cove; (71) Mugford. Previously: BM: Nachvak-Nain. P: Hopedale (Weiz). M: Cape Chidley (Bell).

Saxifragaceæ:

Parnassia parviflora, DC. (65) Saglek Bay; (36) Nachvak. Previously: W: L'anse au Mort, Holton, Forteau, Long Point.

Ribes lacustre, Poir. (Swamp Gooseberry). E. B. D.: Great Caribou Island? Previously: W: L'anse au Clair, L'anse au Mort. F: Red Bay.

Ribes prostratum, L'Her. (Fetid Currant). E. B. D.: Mosquito Bight? Previously: P: Hopedale (Weiz). W: S. Michaels, L'anse au Clair.

Sazifraga aizoides, L. (59) Saglek-Ramah (Sorviluk River). Previously: BM: Nachvak-Nain. P: southeast coast of Lab. (Butler); Hopedale (Weiz). W: L'anse au Mort. M: Cape Chidley (Bell).

†Saxifraga Aizoon, Jacq. (143, 145) Pomiadluk; (73) Mugford; $(4,12)$ Nachvak. F. B. D.: Saglek Bay. Previously: P: Coast of Lab. (Morrison); Hopedale (Weiz).

Saxifraga cæspitosa, L. (185) Southern Lab.; (20) Mt. Faunce. E. B. D.: This or a var. at Pottle's Cove, Ford Harbor, Saglek Bay. Previously: W: Battle Harbor. M : Cape Chidley (Bell). P : var. Gronlandica, Hopedale (Weiz) ; Forteau (Butler); Nachvak (Bell).

Saxifraga cernua, L. (144) Pomiadluk. E. B. D.: Saglek Bay? Previously : BM : Nachvak-Nain. P: Hopedale (Weiz) ; Coast of Lab. (Pursh). M: Cape Chidley (Bell).

*Saxifraga Hirculus, L. (196) Southern Lab.; (84) Port Manvers.

Saxifraga nivalis, L. (24) Mt. Faunce. Previously: BM : (var.) Nachvak-Nain. P : Hopedale (Weiz) ; Coast of Lab. (Pursh). W : Bolster Rocks (Bull). M : Cape Chidley (Bell).

Saxifraga rivularis, L. (48) Hebron-Nachvak. E. B. D. : Saglek Bay. Previously : BM : Cape Chidley. P : Hopedale (Weiz). W : Battle Harbor, Holton. M : Nachvak (Bell). 
†Saxifraga tricuspidata, Retz. (32) Nachvak. E. B. D. : Saglek Bay. Previously: BM : Nachvak-Nain. P : Coast of Lab. (McGill Col. Herb.).

Saxifraga sp. (197) Southern Lab. ; (70) Mugford.

\section{Crassulaceæ :}

Sedum Rhodiola, DC. (Roseroot). E.B. D. : Very variable, and perhaps several varieties or even species. Common at almost all stations as far north as Hebron. Previously : BM : Nachvak-Nain. P: Hopedale (Weiz). W: frequent along the coast. M : Cape Chidley (Bell).

Droseraceæ :

†Drosera rotundifolia, L. (Sundew). E. B. D.: Great Caribou Island, Aillik-Mokkovik. Previously : P : Coast of Lab. (Hooker); Hopedale (Weiz).

\section{Halorageæ :}

Hippuris vulgaris. L. (Mare's Tail). (134, 159) Brig Harbor Island. E. B. D.: Jigger Island; Iterungnek. Previously : BM : Cape Chidley. P: Hopedale (Weiz). W : Fox Harbor.

\section{Onagraceæ :}

Epilobium alpinum, L., var. majus, Gray. (63) Hebron-Nachvak. Previously (E. Hornemanni Reichenb.): W: Pinware, Cartwright, Forteau, Blanc Sablon, Pack's Harbor. F : Mallijak (Hamilton Inlet), Mokkovik, Ramah, Okkak.

Epilobium angustifolium, L. (E. spicatum, Lam.) (Fireweed, Willow Herb). (271) American Tickle (Seal Islands); (252) Pottle's Cove; (133) Ford Harbor. E. B. D.: This or the following common at Mosquito Bight, Aillik Bay. Iterungnek, Nachvak. Previously : BM: Nachvak-Nain. P: Hopedale (Weiz). W: southern Lab., Sandwich Bay.

*Epilobium angustifolium, Lam., forma stenophylla, Hausch. (299) St. Charles River; (97) Ford Harbor.

Epilobium palustre, L. ; var.? (269) American Tickle (Seal Islands). Previously : L : Coast of Lab. P : (E. lineare) Hopedale (Weiz). W : Pack's Harbor, Forteau, Blanc Sablon, Battle Harbor, Mullin's Cove.

\section{Umbelliferæ :}

Archangelica sp.? (298) St. Charles River; (277, 278) American Tickle (Seal Islands). F. B. D. : Abundant at Pottle's Cove, Jigger Island. Previously: (A. atropurpurea, Hoffm.) : BM : NachvakNain. P : Hopedale (Weiz). W : Battle Harbor.

*Cœlopleurum actæifolium, Coulter \& Rose (fide B. L. R.) (276) American Tickle. E. B. D. : Mosquito Bight. Previously only C. Gmelini, Ledeb.

Genus unknown : $(261,262)$ Pottle's Cove. 
Cornaceæ :

Cornus Canadensis, L. (Bunchberry). E. B. D. : Apparently several varieties: very common everywhere as far north as Ford Harbor. Previously : BM : Nachvak-Nain. P : Forteau (Butler); Hopedale (Weiz). W : Straits of Belle Isle and north. Var. suecica, L. noted by BM : Nachvak-Nain.

\section{Caprifoliaceæ:}

Linnæa borealis, L. (Twin-flower). (180) Rodney Mundy Island; (139) Hopedale; (82, 87) Port Manvers; (49a) Hebron-Nachvak. Previously: BM: Nachvak-Nain. P: Hopedale (Weiz). W: Pack's Harbor, Forteau.

Lonicera cærulea, L. (Mountain Honeysuckle). (189) Southern Lab. E. B. D.: St. Charles River, Pomiadluk, Aillik Bay. Previously: W: Indian Harbor, Battle Harbor, L'anse au Loup, Blanc Sablon.

Viburnum pauciflorum, La Pylaie. (Arrow-wood). (154) Mosquito Bight. Previously: F: Red Bay, Webeck, Mokkovik, Okkak.

\section{Compositæ:}

Achillea millefolium, L.; perhaps var. nigrescens, Meyer. (Yarrow). F. B. D.: Pottle's Cove, abundant; Jigger Island. Previously: BM: Nachvak-Nain. P: Hopedale (Weiz).

Antennaria alpina, DC. (Everlasting). (83) Port Manvers. E. B. D.: Some species of Antennaria also at Ford Harbor. Previously : P: Coast of Lab. (Kohlmeister); Hopedale (Weiz). M: Cape Chidley (Bell).

†Antennaria hyperborea, Don. (83a) Port Manvers. Previously: F: Ramah; formerly by Kohlmeister and at Okkak.

Arnica alpina, Murr. (76) Mugford; $(5,11)$ Nachvak. E. B. D.: Common at all points from Port Manvers to Nachvak. Previously: BM: Cape Chidley. P: Coast of Lab. (Torr. and Gray); Hopedale Islands (Weiz). M: Nachvak (Bell).

Artemisia borealis, Pall. (Wormwood). (125) Ford Harbor; (61) Hebron-Nachvak. E. B. D.: Ramah. Previously: varieties only reported by P: Hopedale Islands (Weiz); F: Ramah. M: Coast (Kohlmeister).

Aster radula, Ait. (274) Hopedale (Sept.). Previously: W: Battle Harbor, L'anse au Loup. Var. stricta by P: Hopedale (Weiz);
W: Square Islands, Capstan Island.

†Crepis nana, Richardson. (58) Ramah. Previous1y: F: Ramah. Erigeron uniflorus, L. (Fleabane). (74) Mugford; (31) Nachvak. E. B. D.: Iterungnek-Saglek. Previously: BM: Cape Chidley, Nachvak-Nain. P: Hopedale (Weiz); coast of Lab. (Kohlmeister).

Hieracium vulgatum, Fries. (Hawkweed). (92) Mugford. Pre- 
viously: P: Hopedale (Weiz); coast of Lab. (Kohlmeister). F: Ramah.

†Petasites palmata, Gray. (Sweet Coltsfoot). (281) Pomiadluk. F. B. D.: Aillik Bay, Iterungnek, Saglek. Previously: P: coast of Lab. (Hooker); Hopedale Islands (Weiz).

Senecio pauciflorus, Pursh. (Groundsel, Ragwort). (75) Mugford. E. B. D.: Ramah-Nachvak. Previously: (S. aureus, L., var. borealis, T. \& G.): BM: Nachvak-Nain. P: Hopedale Islands (Weiz).

†Senecio vulgaris, L. (267) St. Francis Harbor; (275) Hopedale (Sept.). Previously: F: Hopedale.

Solidago macrophylla, Pursh. (Golden-rod). (283) Southern Lab. (285) Hare Island; (253) Pottle's Cove; (67) Hebron; (28) Nachvak. Previously: BM: Nachvak-Nain. P: Hopedale (Weiz). W: Forteau, L'anse au Clair, Battle Harbor, Deep Water Creek, Venison Tickle.

Solidago Virga-aurea, L. (151) Pomiadluk; (109)? Ford Harbor. E. B. D.: This or the previous also at Rodney Mundy Island, Aillik Bay, Hebron, Iterungnek, Saglek; common. Previously: (var. alpina): BM: Nachvak-Nain. P: Hopedale (Weiz).

Taraxacum dens-leonis, Desf. (Dandelion). (152) Mosquito Bight; (126) Ford Harbor. E. B. D.: Pottle's Cove, Jigger Island, HebronIterungnek, Ramah-Nachvak. Previously: (T. officinale): W: Battle Harbor and other places. F: Ramah. Varieties reported by BM: Cape Chidley, Nachvak-Nain; P: Hopedale (Weiz).

Genera unknown: (232) Seal Islands; (256) Pottle's Cove.

\section{Campanulaceæ:}

Campanula sp. (Harebell). E. B. D. : Common from Port Manvers northward. Probably one or more of the following species. Previousiy: (C. rotundifolia): W: Battle Harbor, Straits of Belle Isle. (C. rotundifolia var. arctica): P: Forteau (Stearns); Hopedale (Weiz). (C. uniflora): BM: Cape Chidley. P: Hopedale (Weiz). (C. Scheuchzeri var. heterodoxa): BM: Cape Chidley, Nachvak-Nain. M (III, 560): This is to be referred to C. rotundifolia.

\section{Ericaceæ:}

Andromeda polifolia, L. (198) Great Caribou Island. Previously: P: Hopedale (Weiz). W: Indian Harbor, Square Islands, etc.

Arctostaphylos alpina, Spreng. (Alpine Bearberry). (187) Southern Lab.: (169) Rodney Mundy Island; (2) Nachvak. These specimens have leaves only, and are therefore named with some doubt; but are certainly identical with what has previously been so identified. F. B. D.: Very common at all stations throughout the coast region. Berries without much flavor and not used by the natives. Previously: BM: Cape Chidley, Nachvak-Nain. P: Hopedale (Weiz). W: Battle Harbor, L'anse au Loup. 
Bryanthus taxifolius, Gray. (214, 216, 238) Southern Lab. E. B. D. : Common at least as far north as Saglek. Specially noted at Great Caribou Island, Sloop Harbor (near Seal Islands), Pottle's Cove, Rodney Mundy Island, Ford Harbor, Iterungnek-Saglek. Previously: BM: Nachvak-Nain. P: Hopedale (Weiz). W: Battle Harbor, Seal Islands, L'anse au Clair.

Cassandra caliculata, Don. (Leather-leaf). (221) Southern Lab. E. B. D.: Great Caribou Island; abundant at Sloop Harbor (Sea1 Islands). Previously: P: Coast (Hooker); Square Island Harbor (Mann). W: Battle Harbor.

Cassiope hypnoides, Don. (101) Island near Ford Harbor. E. B. D.: Iterungnek-Saglek. Previously: BM: Cape Chidley. P: Hopedale (Weiz). M: Nain (Bell).

Cassiope tetragona, Don. (57) Hebron-Nachvak. ㅍ. B. D.: Not uncommon all the way from Hebron to Nachvak. Proviously: P: Hopedale (Weiz); coast (Kohlmeister); Nain, Nachvak (Be11).

Kalmia angustifolia, L. (Sheep Laurel), (226) St. Charles River. F. B. D.: Sloop Harbor (Seal Islands); rare. Previously: P: Coast (Morrison). W: West St. Modest, Chatham, Battle Harbor.

Kalmia glauca, Ait. (Pale Laurel). (227) St. Charles River; (176) Rodney Mundy Island. F. B. D.: Great Caribou Island, Sloop Harbor (Seal Islands), Ford Harbor. Previously: BM: Nachvak-Nain. P: Hopedale (Weiz). W: Battle Harbor and a few other places.

Ledum latifolium, Ait. (Labrador Tea). (171, 172, 173) Rodney Mundy Island; (19) Nachvak. E. B. D.: see Ledum sp., below. Previously: BM: Nachvak-Nain. P: Hopedale (Weiz); coast (Morrison).

Ledum palustre, L. (240) Southern Lab.; (164) Rodney Mundy Island. F. B. D.: see Ledum sp., below. Previously: BM: Cape Chidley, Nachvak-Nain. P: Hopedale (Weiz); coast (Morrison). W: Seal Islands, Pack's Harbor, Snack Cove.

Ledum sp. F. B. D.: Ledum is exceedingly common at all places on the coast. L. latifolium is the more abundant southward, L. palustre toward the north. Either the L. palustre is very variable, or an intermediate species exists along with the latter. In appearance it certainly seems distinct from the other two: its leaves are intermediate between the oblong leaves of the latifolium and the linear shape of the palustre; its capsule is short-oval; its number of stamens varies within the same cluster of flowers from 5 to II, mostly from 7 to 9 . Its distribution is the same as that of L. palustre. This may be the $\mathbf{L}$. palustre var. dilatatum (Wahl) of Macoun (II, 3OI), having broader leaves and sometimes short oval capsule, approaching L. latifolium; and reported by him only from the Pacific coast. 
Loiselearia procumbens, Desv. (Alpine Azalea). (218, 239) Southern Lab. E. B. D.: Great Caribou Island, Pottle's Cove, Rodney Mundy Island, Brig Harbor Island. Common in the more southern, rare in the more northern localities. Previously: BM: NachvakNain. P: Hopedale (Weiz). W: Battle Harbor, Seal Islands.

Moneses uniflora, Gray. (Pyrola uniflora, L.). (136) Hopedale. Previously: P: Hopedale (Weiz). W: Turner's Head, Hamilton Inlet, Venison Tickle, St. Michael's, L'anse au Clair.

*Pyrola chlorantha, Swartz. E. B. D.: Port Manvers. Previously: Coast (Morrison, Richardson, Gray).

*Pyrola rotundifolia, L. (Wintergreen, Shin-leaf). (8.5 Port Manvers.

Pyrola rotundifolia, L., var. pumila, Hook. (fide B. L. R). (9) Nachvak. E. B. D.: Hopedale, Ford Harbor, Iterungnek-Saglek. Previously: BM: Cape Chidley, Nachvak-Nain. P: Hopedale (Weiz). W: Battle Harbor.

Rhododendron Lapponicum, Wahl. (60) Hebron-Nachvak. Previously: BM: Nachvak. P: Hopedale (Weiz).

† Vaccinium Canadense, Kalm.? (228) St. Charles River. Previously: B: Hamilton River.

Vaccinium Pennsylvanicum, Lam., var. angustifolium, Gray. (Blueberry; Hurts). (228)? St. Charles River. E. B. D.: Great Caribou Island, Rodney Mundy Island. Previously: P: Hopedale (Weiz); Nain (Lundbery). W: Snack Cove, Sandwich Bay.

Vaccinium uliginosum, L. (Blueberry). E. B. D.: Great Caribou Island, Rodney Mundy Island, Brig Harbor Island, Ford Harbor, Mugford, and abundant all the way from Hebron to Nachvak. Previously: BM: Cape Chidley, Nachvak-Nain. P: Hopedale (Weiz). W: Blanc Sablon, Deep Water Creek, Seal Islands, Hamilton Inlet.

Vaccinium Vitis-Idæa, L. (Mountain Cranberry, Redberry). (222) Southern Lab.; (235) Pottle's Cove; (167) Rodney Mundy Island. E. B. D.: Abundant everywhere as far north as Hebron. Previously: BM: Cape Chidley, Nachvak-Nain. P: Hopedale (Weiz). W: Abundant and widely distributed.

Vaccinium sp. (168) Rodney Mundy Island.

\section{Diapensiaceæ:}

Diapensia Lapponica, L. (204) Southern Lab.; (174)? Rodney Mundy Island. E. B. D.: Common almost everywhere throughout the coastal region. Previously: BM: Cape Chidley, NachvakNain. P: Hopedale (Weiz).

Plumbaginaceæ:

Armeria (statice) vulgaris, Willd. (Common Thrift, Sea Pink). (130) Ford Harbor; (102) Island near Ford Harbor; (10, 18) 
Nachvak. E. B. D.: Common everywhere north of Ford Harbor. Previously: BM : Cape Chidley, Nachvak-Nain. P: Hopedale (Weiz). Primulacer:

Primula Mistassinica, Michx. (155) Jigger Island. Previously: P: Forteau (Butler); Hopedale (Weiz). W: Battle Harbor.

Primula farinosa, L. (Bird's-eye Primrose). (245) Pottle's Cove. Previously: BM: Nachvak. P: Hopedale (Weiz). W: Sandwich Bay, Battle Harbor, Long Point (Hamilton Inlet), L'anse au Clair.

Trientalis Americana, Pursh. (Star-flower). E. B. D.: Great Caribou Island, Pottle's Cove, Mosquito Bight, Aillik Bay, Ford Harbor, and Iterungnek-Saglek. Previously: P: Coast (Hooker); Hopedale (Weiz); W: Appears to be quite common everywhere.

\section{Gentianaceæ:}

* Gentiana propinqua, Rich. (64) Near Saglek Bay, on north bank of river flowing into Kajuktok, southerly slope, about 35 o feet above sea level.

Monyanthes trifoliata, L. (Buckbean). E. B. D.: Near head of Mokkovik Bay. Previously: P: Coast (Morrison); Hopedale (Weiz). W: Holton.

Pleurogyne rotata, Griseb. (268) American Island (Seal Islands); (273) Hopedale (Sept.). Previously: P: Coast (Gray). W: Battle Harbor, Sandwich Bay, Hamilton lnlet.

\section{Borraginaceæ:}

Mertensia maritima, Don. (Sea Lungwort). (297) St. Charles River; (255) Pottle's Cove. E. B. D.: Common on the shore; noted at Jigger Island, Aillik-Mokkovik, Nachvak. Previously: BM: Nachvak-Nain. P: Hopedale (Weiz). W: Straits of Belle Isle, Indian Harbor, St. Michael's.

\section{Scrophulariaceæ:}

†Bartsia alpina, L. (88) Port Manvers; (17) Nachvak. Previously: P: Coast of Lab. (Kohlmeister). M: Nachvak (Bell).

Castilleia pallida, Kunth, var. septentrionalis, Gray. (Painted Cup). E. B. D.: Pomiadluk, Ford Harbor, Iterungnek-Saglek. Previously: BM: Nachvak-Nain. P: Hopedale (Weiz).

$\dagger$ Euphrasia latifolia, Pursh. (30) Nachvak. Previously: F: Mokkovik, Hopedale.

Euphrasia sp. (34) Nachvak. E. B. D.: Some species, perhaps latifolia, perhaps officinalis, noted at Hopedale, Ford Harbor, Port Manvers, Iterungnek, Nachvak. Previously: (E. officinalis): BM: Nachvak-Nain. P: Hopedale (Weiz). W: L'anse au Clair, Battle Harbor, Fox Harbor.

Pedicularis euphrasioides, Steph. (242, 279, 280) Southern Lab. (170) Rodney Mundy Island; (95) Port Manvers. E. B. D: Brig Harbor Island, Ford Harbor, Iterungnek-Saglek. Previously: BM: 
Nachvak-Nain. P: Hopedale (Weiz). W: Sandwich Bay (Quinton); Holton (How), M: Coast (Kohlmeister).

Pedicularis flammea, L. (243) Southern Lab. E. B. D.: Pottle's Cove, Iterungnek-Saglek. Previously: BM: Cape Chidley, Nachvak-Nain. P: Hopedale (Weiz); coast (Kohlmeister).

Pedicularis Grœnlandica, Retz. (96) Port Manvers. E. B. D.: Pomiadluk, Iterungnek-Saglek. Previously: BM: Nachvak-Nain. P: Hopedale (Weiz).

†Rhinanthus Crista-galli, L. (Yellow Rattle). E. B. D.: Hopedale; Iterungnek-Saglek? Previously: P: Hopedale (Weiz).

Veronica alpina, L. (Speedwell). (89) Port Manvers, IterungnekSaglek. Previously: BM: Cape Chidley. P: Hopedale (Weiz); Nain (Lundberg).

\section{Lentibulariaceæ:}

†Pinguicula villosa, L.? (166) Rodney Mundy Island; (6, 13) Nachvak. Previously: P: Hopedale(Weiz). M: Labrador (Gray).

Pinguicula sp. (163) Jigger Island; (146) Pomiadluk. E. B. D.: Two species noted, a smaller at Pottle's Cove, Brig Harbor Island; a larger in abundance at Pomiadluk; both at Ford Harbor; one of them at Saglek Bay. Previously: (P.alpina): P: Hopedale (Weiz). (P. vulgaris): BM: Nachvak-Nain. P: Hopedale (Weiz). W. Forteau, Battle Harbor, Seal Islands, Snack Cove, Holton.

\section{Plantaginacer:}

Plantago maritima, L. (Seaside Plantain). (224) St. Charles River; (157) Pomiadluk; (128) Ford Harbor. E. B. D.: Probably this species also at Aillik-Mokkovik, Saglek Bay. Previously: BM: Nachvak-Nain. P: Hopedale (Weiz).

Polygonaceæ:

†Macounastrum (Kcnigia) Islandicum, Small. (100) Island near Ford Harbor. Previously: P: Hopedale (Weiz).

Oxyria digyna, Hill. (Mountain Sorrel). (91) Port Manvers; (29) Nachvak. Previously: BM: Cape Chidley, Nachvak-Nain. P: Hopedale (Weiz).

*Polygonum littorale, Link. (129) Ford Harbor.

Polygonum viviparum, L. (194) Southern Lab.; (296) St. Charles River; (248, 263) Pottle's Cove. E. B. D.: Rodney Mundy Island, Hopedale, Ford Harbor, Port Manvers. Previously: BM: Cape Chidley, Nachvak-Nain. P: Hopedale (Weiz).

Rumex sp. (282) Southern Lab.; (118) Ford Harbor.

\section{Santalaceæ:}

†Comandra livida, Rich. (225) St. Charles River. Previously: P: Hopedale (Weiz); coast (Morrison). 


\section{Betulaceæ:}

Alnus viridis, DC. (Mountain Alder). E. B. D.: Aillik Bay, Mokkovik Bay, Ford Harbor, Iterungnek-Saglek, Nachvak. Previously: BM: Nachvak-Nain. P: Coast of Lab. (Morrison). M: Ford Harbor (Bell).

†Betula nana, L. (Dwarf Birch). (223) Southern Lab.; (229) Seal Island; (337) Pottles Cove. F. B. D.: This or B. glandulosa is common everywhere throughout the coastal region; was seen all the way from St. Lewis Inlet in the extreme south northward to Nachvak. Previously: B. nana and B. glandulosa are given by BM as synonymous and recorded from Nachvak-Nain. No other definite record except of glandulosa by F: Hopedale, Square Island.

\section{Salicaceæ:}

Note:-Some of these were identified by Professor Bailey, but most of them were sent to Professor Rowlee, of Cornell. The initials of the person who is responsible for the name of the specimen are therefore given in each case after the name. In regard to the specimens submitted to him, Professor Rowlee reports: "The willows of northeastern North America and Greenland have not been thoroughly worked out yet, and considerable confusion exists as to their limits, especially in the group including $\mathbf{S}$. Grœnlandica and $\mathbf{S}$. Brownii. Mr. Rydberg has recently described S. atra and S. Labradorica, but I am not convinced yet that they are specifically distinct. I have therefore adopted the more conservative view. $\mathrm{He}$ also has substituted the name $\mathbf{S}$. anglorum for Brownii,--another move that there is still question about."

Salix argyrocarpa, Anders. (W. W. R.). (307) Great Caribou Island. Previously: BM: Nachvak-Nain. P: Forteau (Allen).

Salix Brownii, (Anders) Lundst. (W. W. R.). (184) Southern Lab.; (324, 328 to 335 inclusive) Pottle's Cove. Previously: F: Hopedale, Red Bay, Chateau Bay, Indian Harbor; reported by Macoun from "Labrador (Morrison)" and "Nachvak and Ford's Harbor (Bell)," but included in subsequent lists as S. arctica. M. (V, 356, I890), calls it S. Brownii, Bebb., with synonym S. arctica; and gives among his localities also Cape Chidley (Bell).

†Salix candida, Willd. (W. W. B.). (207) Southern Lab. Previously: P: Forteau Bay (Allen).

*Salix Grœnlandica, (Anders) Lundst. (W. W. R.). (183) Southern Lab.; (165, 233, 234) Seal Islands.

† Salix herbacea, L. (W. W. B.). (66) Various places. E. B. D.: Very common and unmistakable throughout the coast region. Noted specially at Great Caribou Island, Ford Harbor, Port Manvers, Iterungek; seen often in many other places, but not recorded. Previously: BM: Cape Chidley, Nachvak-Nain. P: Coast (Morrison). 
*Salix Labradorica, Reydb. (S. Brownii ; see Bull. N. Y. Bot. Garden, vol. I, No. 4, p. 274.-W. W. R.). (208) Southern Lab.

†Salix phylicifolia, L. (W. W. R.). (336) Pottle's Cove. Previously: P: Nain and Ford's Harbor (Bell).

*Salix uva-ursi, Pursh. (W. W. B., fide Fernald). (182) Southern Lab.; (230) Seal Island. E. B. D.: Great Caribou Island, Ford Harbor. Previously: P: Coast (Kohlmeister); Dead Islands (Allen).

†Salix vestita, Pursh. (W. W. R.). (140) Aillik Bay; (347) Pomiadluk. Previously: BM: Nachvak-Nain. P: Coast (Kohlmeister).

\section{Empetraceae:}

Empetrum nigrum, L. (Crowberry, Curlew-berry). (215) Southern Lab. E. B. D.: The most abundant phenogamous plant of Labrador ; found in large quantities at all places visited. Its very numerous berries are not attractive when raw : the skin is tough, and the contents are only a mass of large dry seeds and a watery almost tasteless juice. But when cooked and sweetened the toughness of skin and seeds disappears, and it develops a delicious flavor. In spite of its exceeding abundance, the only previous references in authorities consulted are : Low : abundant throughout the semi-barren and barren regions of the peninsula, growing freely on the coast and inland. BM : Nachvak-Nain. P: Hopedale (Weiz). M: Cape Chidley (Bell).

\section{Coniferæ :}

*Abies balsamea, Miller ? (Balsam Fir). E. B. D. : Pottle's Cove ; this has been recorded previously only from the interior (Low ; but see also Bell, Geol. Surv. Can., I884, p. I3 DD) ; and as I brought no specimen of it, I cannot now feel absolutely sure of the identification.

†Juniperus communis, L., var. alpina, Gaud. (Juniper, Dwarf Cedar). E. B. D. : Pottle's Cove, Rodney Mundy Island. Previously : P : Coast of Lab. (Hooker). M : Labrador (Lawson \& How).

Larix Americana, Michx. (Larch, Tamarack, etc). E. B. D.: Great Caribou Island, Pomiadluk, Aillik-Mokkovik, Hopedale. Previously: BM: Nachvak-Nain P: (Hooker). Low : probably the hardiest tree of the sub-arctic forest belt: it grows everywhere throughout the Labrador Peninsula, and is probably next in abundance to the black spruce. F: Red Bay; grows considerably north of Nain; an abundant tree.

†Picea alba, Link. (White Spruce). E. B. D.: Great Caribou Island, Rodney Mundy Island, Pomiadluk. Previously : P : (Hooker). F:Tub Harbor. Low : found everywhere throughout the wooded area of the peninsula, but is not everywhere common; . . . its distribution appears to depend altogether on the soil. 
†Picea nigra, Link. (Black Spruce). E. B. D.: Great Caribou Island, St. Charles River, Pottle's Cove, Rodney Mundy Island, Aillik-Mokkovik, Ford Harbor, Nain. Previously : P : (Hooker). F : Chateau Bay. Low : the most abundant tree of Labrador and probably constitutes over ninety per cent of the forest.

Orchidaceæ :

$\dagger$ Habenaria dilatata, Gray. E. B. D.: Aillik, Mokkovik. Previously : P : Hopedale Islands (Weiz).

†Habenaria obtusata, Rich. E. B. D. : Aillik Bay. Previously : F : Indian Harbor.

\section{Iridaceæ :}

Iris sp. E. B. D. : Great Caribou Island, Sloop Harbor (Seal Islands), Rodney Mundy Island, Jigger Island, Hopedale. Previously : P : I. Hookeri at Hopedale Island (Weiz). F: I. versicolor at Battle Harbor.

\section{Liliaceæ :}

Clintonia borealis, Raf. E. B. D. : Great Caribou Island. Previously : F : Chateau Bay, Northwest River, Pitts Arm, Henley Harbor, Red Bay.

†Smilacina trifolia, Desf. (201) Southern Lab. E. B. D. : Great Caribou Island, Pottle's Cove. Previously : F : Battle Harbor, Tub Harbor.

Streptopus sp. (193) Southern Lab. F. B. D.: Great Caribou Island, Brig Harbor Island, Mosquito Bight, Aillik Bay. Previously: (S. roseus) : P : Hopedale (Weiz). (S. amplexifolius) : F : Red Bay, Indian Harbor, Hopedale, Mallijak.

Tofieldia palustris, Hudson. (158) Brig Harbor Island; (98) Island near Ford Harbor. E. B. D.: Iterungnek-Saglek. Previously: BM : Nachvak-Nain. P: Hopedale (Weiz); coast (Hooker).

Juncacer:

*Juncus Castaneus, Smith? (39) Nachvak. Previously: P: Ungava Bay (Barnston).

Juncus trifidus, L. (107) Ford Harbor. Previously: F: Ramah, Carroll Cove. B: Grand River.

†Luzula arcuata, Meyer. (310) Hebron-Nachvak. Previously: BM: Nachvak-Nain. P: Ungava Bay (Barnston). M: Cape Chidley (Bell).

*Luzula hyperborea, R. Br. (26) Mt. Faunce: 3,500 to 4,400 feet above sea level.

\section{Cyperaceæ:}

*Carex compacta, R. Br. (311) Hebron-Nachvak. Previously: M: Cape Chidley (Bell); but not included in his later list in Low unless as C. rotundata (Wahl). 
*Carex filifolia, Nutt. (38) Nachvak. "Apparently first station east of Manitoba" (Fernald).

+Carex rariflora, Smith. (fide Fernald). (284, 289, 291) Hare Island (St. Lewis Inlet). Previously: F: Hopedale, Webeck Harbor.

†Carex rigida, Good. (C. vulgaris, Fries, var. hyperborea, Boott.). (339) Southern Lab.; (313) Brig Harbor Island; (104, 108, 115) Ford Harbor; (69) Hebron; (40) Hebron-Nachvak. Previously: BM: Cape Chidley, Nachvak-Nain.

*Eriophorum alpinum, L. (338) Southern Lab.; (318) Jigger Island; (114)? Ford Harbor.

*Eriophorum polystachyon, L. (340) Southern Lab.; (346) Locality unknown; (323) ? Port Manvers. Previously: P: var. angustifolium at Hopedale (Weiz).

Eriophorum sp. E. B. D.: One or more species grow freely from Hebron northward.

Scirpus cæspitosus, L. (303) St. Charles River. Previously: BM : Nachvak-Nain. P: Hopedale (Weiz).

Scirpus sp. (236) Seal Islands.

\section{Gramineæ:}

†Agrostis sp. (110) Ford Harbor. Previously only A. rubra, L., by F: Hopedale, Hebron.

†Calamagrostis Canadensis, Beauv. (113) Ford Harbor. Previously: B: Grand River.

Calamagrostis sp. (292) Hare Island; (321) Port Manvers; (309) Nachvak.

*Catabrosa aquatica, (L.). Beauv. (Aira aquatica, L.). (272) American Island (Seal Islands).

$\dagger$ Elymus arenarius, L. (E. mollis, Trin.). (325) Pottle's Cove. Previously: BM: Nachvak-Nain.

†Festuca brevifolia, R. Br. (314) Brig Harbor Island. Previously: BM: Nachvak-Nain.

*Festuca rubra, L. (288) Hare Island; (103) Ford Harbor. Britton $\&$ Brown refer this to Labrador, but I find no other reference to any part of the Peninsula.

†Hierochloe alpina, Roem. \& Schl. (105, 116) Ford Harbor; (42) Hebron-Nachvak. Previously: BM: Cape Chidley, NachvakNain. P: Ungava Bay (Barnston).

†Hierochloe borealis, Roem. \& Sch1. (345) Aillik Bay; (30a) Nachvak. Previously: F: Mallijak (Hamilton Inlet).

†Poa alpina, L. (286) Hare Island; (80) Port Manvers or Mugford; (112) Ford Harbor; (312) Hebron-Nachvak. Previously: BM: Cape Chidley. M: Nain (Bell). 
†Poa glumaris, Trin. (344) Aillik Bay. Previously: F: Nain; southern coast.

†Poa laxa, Hænke. (327) Pottle's Cove; (111) Ford Harbor. Previously: F: Ramah.

*Poa nemoralis, L. (319) Jigger Island.

Poa sp. (287) Hare Island; (106) Ford Harbor.

$\dagger$ Phleum alpinum, L. (322) Port Manvers. Previously: F: Ramah.

$\uparrow$ Trisetum subspicatum, Beauv., var. molle, Gray. (315) Mugford; (79) Mugford or Port Manvers; (41, 44, 45, 46) HebronNachvak. Previously: BM: Cape Chidley, Nachvak-Nain.

Genus unknown: (300, 301, 302, 305) St. Charles River.

Equisetaceæ:

Equisetum sylvaticum, L. (237) Seal Island; (81) Port Manvers or Mugford; (251) Pottle's Cove. F. B. D.: Rodney Mundy Island. Jigger Island. Previously: BM: Nachvak-Nain. P: Hopedale (Weiz).

Filices:

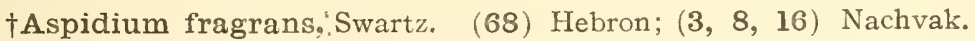
Previously: BM: Cape Chidley.

†Aspidium spinulosum, Swartz. (293,294) Southern Lab. Previously: B: Grand River. F. reports var. dilatatum as probably the commonest form of the species in Labrador.

Phegopteris Dryopteris, Fée. (290) Hare Island. Previously: F: Webeck Harbor, Tub Harbor, Mokkovik. B: Grand River.

†Phegopteris polypodioides, Fée. (179) Rodney Mundy Island. Previously: F: Battle Harbor, Webeck Harbor.

†Woodsia Ilvensis, R. Br. (148) Jigger Island; (135) Aillik Bay; (37) Nachvak. Previously: F. Ramah.

\section{Lycopodiaceæ:}

$\nmid$ Lycopodium alpinum, L. (316) Mugford. Previously: F: Davis Inlet.

†Lycopodium annotinum, L. (343) Southern Lab. Previously: B: Grand River. F reports var. pungens from Hopedale, Chateau Bay, Red Bay.

*Lycopodium lucidulum, Michx. (341) Southern Lab. (320) Jigger Island.

†Lycopodium Selago, L. (342) Southern Lab.; (317) Jigger Island; (308) Nachvak. Previously: BM: Cape Chidley. P: Nain and Ford Harbor (Bell). 


\section{B. MOSSES AND HEPATICS.}

Note.-The; examination of these plants is still incomplete. $\mathbf{M r}$. Collins reports on them as follows: "Specimens collected (mostly without fruit) II4; specimens determined, about 85 ; species determined, 29. Thirteen of these have already been reported from several localities on the Labrador coast, Five of them have been reported from one locality only. Of the remaining eleven, two (Dicranum fuscescens, Polytricum piliforum) have been indefinitely reported from "Labrador;" five (Brachythecium salebrosum, Conostomum boreale, Dicranum Bergeri, Pogonatum capillare, Polytricum commune, are very common throughout North America and are reported from both Greenland and Newfoundland, and it would be very surprising if they did not occur on the Labrador coast, although there is no previous record of them; three others are entirely new : Mnium punctatum elatum is known in Miquelon, but the type has been reported also from the Labrador coast; Barbula ruralis is known previously only from further north and west; Splachnum Wormskjoldii seems to be a very good find, having been known heretofore only from high northward-Smith Sound $\left(78^{\circ}-82^{\circ}\right.$ N.), Greenland, Norway, Lapland, Spitzbergen, and N. Asia; and finally one (No. 26b, see below), if a variety of Pogonatum urnigerum, is here found much farther north and at a higher altitude than previously known. Most of the undetermined specimens are apparently more or less common species (or duplicates), although, from a hasty perusal, a few of them may prove interesting, as I cannot place them without further study."

For the determination of previously recorded localities, "Paris: Index Bryologicus (I894-I900)" has been consulted, in addition to the authorities already referred to. Specimens recorded below merely as from the "Atlantic coast of Labrador" were gathered in a variety of places and seemed to the collector to be so common and widely distributed that no more definite local references were made.

\section{Musci:}

Andreæa petrophila, Ehrh. (1) Atlantic coast of Labrador; (30) Mt. Faunce. Previously: M: Deep Water Creek, Venison Tickle, Battle Harbor, Bolster Rocks (Waghorne).

Aulacomnium palustre, (L) Schwaegr. (44, a form, 62, 90, 94) Atlantic coast of Labrador; (32a, 35b, 70, 73, 77b) Nachvak. Previously: M: Battle Harbor, Cape Charles, Fox Harbor (Waghorne); Whale Island, Chateau Bay (Allen).

Aulacomnium turgidum, (Wahlen.) Schwaegr. (116a) Atlantic coast of Labrador. Previously: M: Seal Islands, Battle Harbor (Waghorne).

*Barbula ruralis, (L) Hedw. (20) Pottle's Cove. 
*Brachythecium salebrosum var. palustre, Schpr. (?114) Atlantic coast of Labrador.

Ceratodon purpureus, Brid. (78b, 79) Atlantic coast of Labrador. Previously: M: Squaw Head, Venison Tickle (Waghorne).

*Conostomum boreale, Swartz. (72) Nachvak.

*Dicranum Bergeri, Bland. (83a) Atlantic coast of Labrador.

*Dicranum fuscescens, Turn.; (or possibly D. congestum.-J.F. C.) (13b, 50b) Atlantic coast of Labrador.

†Grimmia apocarpa, (L) Hedw. (107b) Atlantic coast of Labrador. Previously: M: Battle Harbor (Waghorne).

†Hylocomium splendens, (Hedw.) Bry. Eur. (2l) Pottle's Cove. Previously: M: Battle Harbor (Waghorne).

†Hypnum cordifolium, Hedw. (16) Hopedale. Previously: M: Battle Harbor (Waghorne).

Hypnum revolvens, Swz. (54, 113) Atlantic coast of Labrador. Previously: M: Battle Harbor, Square Island (Waghorne).

Hypnum Schreberi, Willd. (45b, 51, 61, 63b, 64a, 87a) Atlantic coast of Labrador. Previously: B: Hamilton River; M: Deep Water Creek, Battle Harbor (Waghorne).

Hypnum stramineum, Dicks. (12, 57a) Atlantic coast of Labrador. Previously: M: Cape Chidley (Bell); Indian Harbor, Venison Tickle (Waghorne).

Hypnum uncinatum, Hedw. (7,57c) Atlantic coast of Labrador. Previously: M: Cape Chidley (Bell); Square Island, Seal Islands, Battle Harbor (Waghorne).

* Mnium punetatum var. elatum, Schpr. $(17,24)$ Rodney Mundy Island. Previously: (Mnium punc. non var.) M: Battle Harbor (Waghorne).

Pogonatum alpinum, Roehl. (89) Atlantic coast of Labrador. Previously : M : Little Bay Islands, Western Cove, Cape Charles, Deep Water Bay (Waghorne).

*Pogonatum alpinum var., or P. urnigerum, (Beauv.) var. (26b) Mt. Faunce. "It seems to be a form of one of these. It is, however, very different from either in their typical form, especially in regard to size of plant, and size and margin of leaves. I am somewhat more inclined to think it a variety of $P$. alpinum now than I was at the first examination. I am unable (or have been so far) to find a description of any variety of either species which seems to fit your plant. In the absence of fruit, I am afraid it will be somewhat difficult to say with any degree of certainty of which it is a form, unless an authentic specimen can be found somewhere that exactly fits it."-(J. F. C.)

*Pogonatum capillare, Brid. (27) Mt. Faunce. 
*Polytricum commune, L. (15) Ford Harbor; (59, 63d) Atlantic coast of Labrador.

Polytricum juniperinum, Willd. (78a) Atlantic coast of Labrador ; (74) Nachvak. Previously: B : Grand River; BM: Cape Chidley, Nachvak-Nain ; M : Little Bay Islands (Waghorne).

*Polytricum piliferum, Schreb. (107a) Atlantic coast of Labrador. †Polytricum strictum, Banks. (9, 10a, 45c, 50a, 58, 80a, 85b, 99) Atlantic coast of Labrador; (23a) Brig Harbor Island; (35a, 77a) Nachval. Previously: M : Nain (Bell).

Racomitrium canescens, Brid. (34b) Nachvak. Previously: M : Seal Island, Venison Tickle (Waghorne).

†Racomitrium lanuginosum, (Hedw.) Brid. (22b) Brig Harbor Island; $(25,28,29 a, 31 b)$ Mt. Faunce ; 63a, 67, 86a) Atlantic coast of Labrador. Previously : M : near Venison Tickle (Waghorne).

Sphagnum acutifolium, Ehrh. $(65,106)$ Atlantic coast of Labrador. Previously: M: Cartridge Bight, Seal Islands, Spence's Cove (Waghorne).

*Splachnum Wormskjoldii, Hornem. (111b, 112) Seal Island.

Tetraplodon mnioides, (L. f.) Bry. Eur. (109, 110, 11la) Seal Island; (101) Atlantic coast of Labrador. Previously: M: Paroquet Island (Allen); Indian Harbor, Venison Tickle, Battle Harbor, Seal Island (Waghorne).

\section{Hepaticæ :}

Note.-None of these are reported by the previously-named authorities, nor by W. H. Pearson in his List of Canadian Hepatice (1890). All the specimens recorded below are from the Atlantic coast of Labrador, but no more definite locality can be given.

* Blepharostoma trichophyllum, Dum. (3a, 4a.)

*Fimbriaria tenella, Nees. (4c.)

*Jungermannia ventricosa, Dicks. (13a.)

*Lepidozia setacea, Mitt. (? 3b.)

* Marsupella emarginata, Dum. (? 88b.)

*Nardia crenulata, Lindb. ( ? 4b.)

$*$ Ptilidium ciliare, Nees. $\quad(2,6,60,80 b, 86 c$. $)$

\section{LICHENS.}

[Note.-The following report on lichens is by Miss Clara E. Cummings, Associate Professor of Cryptogamic Botany at Wellesley College, who kindly undertook the task of identification. Those recorded from "no definite locality" were gathered at various places on the Atlantic coast of Labrador, between St. Lewis Sound and Hebron.-E. B. D.] 
The latest publication on the lichens of Labrador is the pamphlet entitled Labrador, published by Dr. F. Arnold at Munich in 1896. This is based on the work of Meyer (I), Schlechtendahl (2), Breutel (3), Tuckerman (4), Wainio (5), and Eckfeldt (6), and on specimens collected by the Rev. Mr. Waghorne and communicated to Dr. Arnold by Mr. J. W. EckfeIdt.

(I) Meyer, Ern., De plantis Labradoricis libri tres, 1830. (2) Schlechtendahl, D. F. L. v, Ueber die Flora von Labrador, in Linncea, 1836. (3) Breutel, Flora German. Exsiccata, I832, I843. (4) Tuckerman, Synopsis N.A.L. I, I882; II, I888. (5) Wainio, Monographia Cladoniarium. I, 1876 ; II, I894. (6) Eckfeldt, J. W., An enumeration of the lichens of Newfoundland and Labrador, Bull. Torrey Bot. Club, I895.

The total number of species given in Dr. Arnold's list is one hundred and twenty-seven, besides numerous varieties and forms. The present collection of forty-three specimens includes five species which are not recorded in Dr. Arnold's list, namely, Cetraria Islandica var. platyna, Cetraria cucullata, Theloschistes polycarpus, Lecanora pallescens, and Cladonia bellidiflora var. ochropallida.

r. Cetraria arctica, (Hook.) Tuck. On Mt. Faunce, at an altitude of 3,500-4,000 ft.; also at Nachvak. The species appears in EckfeIdt's enumeration.

2. Cetraria Islandica, (L.) Ach. Mixed with Cetraria cucullata and C. nivalis. Both Arnold and Eckfeldt credit it to Labrador upon material collected by the Rev. Mr. Waghorne, and in my own herbarium I have material collected by him at Battle Harbor.

3. Cetraria Islandica, (L.) Ach., d. platyna (Ach.) Th. Fr. With the preceding species and also mixed with Cladonia rangiferina, $\mathrm{Cl}$. sylvatica and Stereocaulon tomentosum. A specimen in my herbarium was collected by the Rev. Mr. Waghorne at L'anse au Loup.

4. Cetraria Islandica, (L.) Ach., b. Delisæi (Bor.) Schaer. This variety is recorded in Eckfeldt's list, and a specimen in my own herbarium was collected by the Rev. Mr. Waghorne at West S. Modeste.

5. Cetraria cucullata, (Bell.) Ach. On Mt. Faunce, 3,500-4,000 ft. altitude, and at Nachvak, with Cetraria arctica, C. Islandica and Cladonia rangiferina. Evidently this is one of the most common species as indicated by the fragments mixed with many other lichens, though it does not appear in Dr. Arnold's list.

6. Cetraria nivalis, (L.) Ach. On Mt. Faunce, 3,500-4,00o ft. altitude; other specimens have no definite locality recorded. It occurs alone and mixed with Cetraria Islandica and species of Cladonia. It is given in Eckfeldt's enumeration, and a specimen in my herbarium was collected by the Rev. Mr. Waghorne at Battle Harbor.

7. Cetraria Fahlunensis, (L.) Schaer. The species is recorded in Eckfeldt's enumeration, and my herbarium contains a specimen collected by the Rev. Mr. Waghorne at Battle Harbor. 
8. Cetraria glauca, (L.) Ach., v. fusca (Flot.) Tuck. Recorded also in Eckfeldt's enumeration.

9. Alectoria divergens, (Ach.) Nyl. On Mt. Faunce, 3,500-4,000 ft. altitude, with Alectoria nigricans. Various specimens were collected, either growing alone or mixed with A. nigricans, Cetraria, nivalis or species of Cladonia. The species is recorded in Eckfeldt's enumeration. It also appears in Arnold's list, having been collected at Long Island. It is represented in my herbarium by specimens collected by the Rev. Mr. Waghorne at Long Island and Battle Harbor.

Io. Alectoria jubata, (L.) Ach. Recorded by Eckfeldt.

II. Alectoria nigricans, (Ach.) Nyl. On Mt. Faunce, 3,500-4,000 ft. altitude, intermixed with Cladonia, Cetraria, Alectoria nigricans and fragments of Sphærophoron. Specimens were also collected for which no definite locality was given. It is given in Arnold's list as having been collected at Blanc Sablon and at Capstan Island. Eckfeldt records it under the synonym Alectoria ochroleuca (Ehrh.) Nyl., var. nigricans, Ach.; and Tuckerman as A. ochroleuca (Ehrh.) Nyl., "a. rigida, Fr., nigricans, Ach.

12. Alectoria ochroleuca, (Ehrh.) Nyl., c. sarmentosa (Ach.) Nyl. Var. at Mokkovik. Recorded by Eckfeldt and represented in my herbarium by a specimen collected by the Rev. Mr. Waghorne at Battle Harbor.

13. Theloschistes polycarpus, (Elrh.) Tuck. Mt. Faunce, 3,5004,000 ft. altitude. New to Labrador.

I4. Parmelia saxatilis, (L.) Fr. This species is given in Eckfeldt's enumeration and is in my herbarium from Battle Harbor, Labrador, collected by the Rev. Mr. Waghorne. Dr. Arnold reports its occurrence at Capstan Island and at L'anse au Clair.

15. Parmelia saxatilis, (L.) Fr., d. omphalodes Fr. Given in Eckfeldt's enumeration and in my herbarium from Battle Harbor, collected by the Rev. Mr. Waghorne.

16. Parmelia physodes, (L.) Ach., b. obscurata, Ach. Given in Eckfeldt's enumeration. A very variable form. In some specimens the lobes of the thallus are very long and narrow, as in var. vittata, in others wide and ventricose-inflated, as in var. enteromorpha, while in still others the lobes are extremely abbreviated and closely massed.

17. Umbilicaria cylindrica, (L.) Delis. The specimens are well fruited. The species is recorded by Tuckerman and Eckfeldt. Collected also at West S. Modeste by the Rev. Mr. Waghorne, and represented in my herbarium. No. 1136 in Breutel's Exsiccata under Gyrophora.

18. Umbilicaria proboscidea, (L.) DC. Mt. Faunce, 3,500-4,000 ft. altitude. The specimens were fertile. Recorded also by Eckfeldt; recorded by Arnold as occurring at Forteau under the synonym Gyrophora.

19. Umbilicaria hyperborea, Hoffm. Fertile. The species is listed by Eckfeldt, and also represented in my herbarium by a specimen 
from Blanc Sablon collected by the Rev. Mr. Waghorne. Arnold lists it as collected at L'anse au Loup.

20. Umbilicaria vellea, (L.) Nyl. Nachvak. Only sterile specimens. Given in Eckfeldt's enumeration.

2I. Nephroma arcticum, (L.) Fr. Specimens fine and well fruited. Recorded by Eckfeldt; also in Arnold's list as collected by Herzberg in Labrador, and as represented in Breutel's Exs. 204.

22. Solorina crocea, (L.) Ach. Only sterile fragments. Recorded by Tuckerman as occurring in Labrador; also given in Eckfeldt's enumeration.

23. Placodium elegans, (Link.) DC. One sterile specimen. Also recorded by Eckfeldt.

24. Lecanora pallescens, (L.) Schaer. Fruit immature, and therefore the determination is somewhat uncertain. New to Labrador.

25. Pertusaria dactylina, (Ach.) Nyl. Recorded by Eckfeldt and also by Arnold as having been found at L'anse au Mort and L'anse au Loup.

26. Stereocaulon tomentosum, Fr. Mt. Faunce, 3,500-4,00 ft. altitude; also various specimens with no definite locality. Evidently quite common. Recorded also by Eckfeldt.

27. Stereocaulon denudatum, Floerk. Nachvak, Mt. Faunce, 3,500-4,000 ft. altitude. Both this and the preceding species were sterile. Given in Eckfeldt's enumeration.

28. Sphærophoron fragile, (Crantz.) Pers. Several specimens, all sterile, differing considerably in appearance. In the typical form the branches of the thallus are spreading and open, but one specimen has the lobes of the thallus very much abbreviated and closely cæspitose. Recorded in Eckfeldt's enumeration.

29. Sphærophoron coralloides, Pers. On Mt. Faunce, 3,500-4,000 ft. altitude, all the specimens sterile; also at Brig Harbor, July 26, 1900; and other specimens with no definite locality. Given in Eckfeldt's enumeration; also in Arnold's list as found at Long Island and at L'anse au Loup.

30. Cladonia pyxidata, (L.) Fr., var. pocillum (Ach.) Flot. No definite locality given. Recorded in Arnold's list as collected by Herzberg at Okak; also given in Eckfeldt's enumeration.

3I. Cladonia gracilis, (L.) Willd., var. choridalis (Floerk.) Schaer. Represented by six specimens, three of which were collected at Nachvak. The specimens vary considerably in size, those from Nachvak being rather short and compact. All the specimens are sterile. Also recorded in Eckfeldt's enumeration.

32. Cladonia rangiferina, (L.) Web. Emend. Mixed with Cetraria nivalis, C. cuculatta, C. Islandica, etc. Everywhere; specially noted at 
Aillik-Mokkovik, Hebron-Iterungnek, Nachvak. Recorded in Arnold's list as collected by Herzberg at Okak. Given in Eckfeldt's enumeration.

33. Cladonia sylvatica, (L.) Hoffm., a. sylvestris, Oed. Nachvak. Given in Arnold's list as Cl. sylvatica. Collected by Herzberg at Okak.

34. Cladonia alpestris, (L.) Rabenh. Everywhere; specially noted at Aillik-Mokkovik, Hebron-Iterungnek. Recorded by Arnold as collected at Blanc Sablon. Given in Eckfeldt's enumeration as Cl. sylvatica var. alpestris.

35. Cladonia uncialis, (L.) Web. No definite locality recorded. Growing with Cetraria nivalis. Wainio states that it was collected in Labrador by Morrison.

36. Cladonia coccifera, (L.) Willd. At Aillik-Mokkovik. Specimens fertile and rather reduced in size. Given in Arnold's list as collected by Herzberg.

37. Cladonia bellidiflora, (Ach.) Schaer. At Aillik-Mokkovik. Specimens are well-fruited. Recorded by Tuckerman as occurring in Iabrador. Given in Arnold's list as collected by Herzberg at Okak, and as appearing in Breutel's Exs. Io3, collected by Henne; also as collected at West S. Modeste. A specimen in my herbarium was collected by the Rev. Mr. Waghorne at L'anse au Clair.

38. Cladonia bellidiflora, (Ach.) Schaer., e. ochropallida, Flot. With the preceding. A very delicate specimen.

39. Cladonia deformis, (L.) Hoffm. No definite locality recorded. Given in Eckfeldt's enumeration without locality. All the specimens are sterile.

40. Cladonia reticulata, (Russell) Wainio. Some of the specimens are very large and much inflated and these are less reticulate than the smaller specimens. Listed by Dr. Arnold on the authority of Tuckerman, who credits the specimen to Mr. W. A. Stearns.

4I. Lecidea albocoerulescens, (Wulf) Schaer., var. flavocoerulescens, Schaer. A small sterile specimen may perhaps be referred here. Eckfeldt records the occurrence of this variety in Labrador.

42. Iuecidea platycarpa, Ach. On rock with the following species.

43. Buellia geographica, (L.) Tuck. Pottle's Cove. On rock. Listed by Dr. Arnold under the synomyn Rhizocarpon geographicum, L.

\section{FUNGI.}

Note.-The fungi were collected along the coast, mainly from Mokkovik, Hopedale, Nain and Nachvak. The remarks in quotation-marks below are from Professor Farlow's notes on the specimens. The only fungi previously reported from Labrador in the lists consulted as named above are: Lycoperdon, Russula, Agaricus, and seven minute species, all given in Bell's list. 
D denotes identification from description.

S " " " " " preserved specimen.

$\mathrm{X}$ “ " " by E. B. D. only.

${ }_{4}$ S. *Boletinus decipiens, Pk. (Boletus decipiens, B. \& C.) “This is Boletus decipiens, I think. The species is really a Boletinus rather than a Boletus. It is not very well known."

${ }_{3}$ S. *Boletus scaber, Fr.? "This is near B. scaber."

IS, 2D. *Boletus variegatus, Swartz. E. B. D.: Noted at Ford Harbor and common all the way between Hebron and Nachvak.

X. Boletus sp. E. B. D.: One or more species noted at Pottle's Cove (two specimens), abundant at Ford Harbor, very abundant at Port Manvers, at Nachvak, and on the return at Nain and Hopedale.

6S. *Collybia lacerata, Lasch.

${ }_{5} \mathrm{~S}$. * Cortinarius sp.

7D. *Cortinarius sp. "A Cortinarius, but no mortal knows the species of that genus." E. B. D.: From Port Manvers, Iterungnek-Saglek.

8D. *Entoloma clypeus, vel aff. E. B. D.: From Port Manvers, Iterungnek-Saglek.

6D. *Hypholoma sp. "The fungus is apparently a Hypholoma, but I do not recognize the species." From Port Manvers.

${ }_{7} \mathrm{~S}$. *Inocybe sp. "An Inocybe not to be named except on microscopical examination."

2S. *Lactarius vellerius, Fr.; " probably."

8S. Lactarius sp. "A small Lactarius, perhaps near L. vietus. It needs to be compared with other species as to microscopic character."

9S. *Lenzites abietina, Fr.

X. *Iycoperdon saccatum, Vahl., probably. Ford Harbor, Iterungnek.

X. *Lycoperdon sp. Port Manvers, Iterungnek.

$\mathrm{X}$. *Peziza? In hot-house at Ramah.

IoS. *Russula lepida, Fr.? " This appears to be R. lepida, but notes on appearance when fresh are needed." Seen at Mugford, Iterungnek, Nachvak.

IoD\&c. Russulæ. " The Russulæ cannot be named without more notes and specimens." Seen in considerable quantity at same places as the last; also at Port Manvers, Nain, Hopedale. 
IX.

\title{
REPORT ON ORNITHOLOGY.
}

\author{
By Henry B. Bigelow.
}

[NotE. -Mr. Rigelow sent his list to the editor with the following words of explanation: "I am enclosing the list of Labrador birds, for which you asked. I suppose you want it condensed, and have made it in fact little more than a list of names. with brief notes on their relative abundance and distribution. I have given no introduction at all, as I suppose your paper will describe the nature of the country so fully as to make one superfluous."

This list was prepared earlier than that published by Mr. Bigelow in $A u k$, January, 1902. The latter has not the same numbering as this, and contains a few additions and corrections. Added are : Botaurus lentiginosus, Tringa alpina pacifica, Spinus pinus, Sylvania pusilla, Sylvania *anadensis. The following changes are made: No. 28 to Aythya marila; 30 to Somateria borealis; 51 to Lagopus albus; 64 to Passerculus sandwichensis labradorius; 75 to Parus atricapillus; 76 to Turdus aliciæ. Numbers 28,35 and 64 are apparently without previous record from this coast.-E. B. D.]

I. Urinator imber. "Loon." Rather uncommon. We met them singly or in pairs in the bays and fiords in August and September. Not found nesting.

2. Urinator lumme. Red-throated Loon. "Wabby." Reported by the settlers as common. We saw only a few, in September.

3. Fratercula arctica. Puffin. Common. One of the more characteristic sea-fowl, of local abundance. Near their rookeries they were very abundant during July. In August they were more generally distributed. We saw comparatively few north of Cape Harrigan.

4. Cepphus grylle. Black Guillemot. Pigeon. Very abundant all along the coast. The most numerous of all the water fowl, after the kittiwakes. Breeding commonly on the smaller islets. Much used by the settlers as an article of food.

5. Uria troile. Murre. Common, but much less so than formerly, owing to "eggers." Breeding still in considerable colonies. Comparatively scarce north of Cape Harrison, though reported to be abundant along the northern coast later in the fall.

6. Uria lomvia. Brünnich's Murre. Rather less common than the last. We saw none north of Hamilton Inlet.

7. Alca torda. Razor-billed Auk. Common, particularly so about Hamilton Inlet, and just north of Belle Isle. At Port Manvers we saw only a few. In July we usually found them in the loose floe-ice.

* The omission of capitals in proper names is in accordance with the wishes of the author. 
8. Alle alle. Dovekie. Reported abundant in fall and winter. I saw only one specimen, off Cape Harrison on Sept. I8th.

9. Stercorarius pomarinus. Pomarine Jæger. Much less common than the two following.

I0. Stercolarius parasiticus. Parasitic Jæger.

II. Stercorarius longicaudus. Long-tailed Jæger. Both this and preceding common, of about equal abundance. Usually with flocks of kittiwakes.

12. Rissa tridactyla. Kittiwake. Most abundant sea-bird. Found everywhere in great numbers.

I3. Larus glaucus. Ice Gull, Burgomaster, Glaucous Gull. More and more common the further north we went. Abundant at Port Manvers. Not seen south of Cape Harrison.

I4. Larus marinus. Black-backed Gull. Abundant. Breeds commonly, though not in colonies.

I5. Larus argentatus smithsonianus. Herring Gull. Common all along the coast.

I6. Larus delawarensis. Ring-billed Gull. I took one young bird at Port Manvers on Sept. 6th. No others seen.

17. Larus philadelphia. Bonaparte's Gull. Rather common about Belle Isle late in September. Not seen further north.

18. Sterna paradisæa. Arctic Tern. A few seen about Belle Isle in July and again late in September.

19. Fulmarus glacialis. Noddy. Rather common off shore with the shearwaters.

20. Puffinus major. Greater Shearwater. Common off shore in large flocks.

2I. Puffinus stricklandi. Sooty Shearwater. Common with the preceding.

22. Oceanodroma leucorhoa. Leach's Petrel. Common, breeding locally in considerable numbers south of Hamilton Inlet. We saw none further north.

23. Sula bassana. Gannet. A few seen in July and September about Belle Isle.

24. Phalacrocorax carbo. Cormorant. A few seen about Belle Isle. None further north.

25. Phalacrocorax dilophus. Double-crested Cormorant. A few seen about Belle Isle, none further north.

26. Merganser serrator. Red-breasted Merganser. Common. Breeding all along the coast.

27. Anas obscura. Black Duck. Rather uncommon on the coast.

28. Aythya marila nearctica. Greater Scaup Duck. One specimen from Dr. Grenfell, shot at Nain, October, I899. 
29. Glaucionetta clangula americana. American Golden Eye. Rare; one near Paul's Island, August I ith.

30. Somateria mollissima borealis. Greenland Eider. Abundant north of Hamilton Inlet.

3r. Somateria dresseri. American Eider. Common on the more southern coast.

32. Oidemia americana. Black Scoter. Common in the fiords in September.

33. Oidemia deglandi. White-winged Scoter. Common along the coast and in the fiords in September.

34. Oidemia perspicillata. Surf Scoter. Common along the coast and in the fiords in September.

35. Anser albifrons gambelli. White-fronted Goose. One specimen from Dr. Hettasch, Hopedale, May, I900.

36. Branta canadensis. Canada Goose. Abundant along the coast in spring, common in fall from September 2oth.

37. Branta bernicla. Brant. Rare. One specimen from Dr. Grenfell, Nain, October, 1899 .

38. Crymophilus fulicarius. Red Phalarope. Not uncommon off shore.

39. Phalaropus lobatus. Northern Phalarope. Common, breeding commonly along most of the coast.

40. Gallinago delicata. Snipe. Rare. Two or three at Cape St. Francis Harbor late in September.

4I. Tringa maculata. Pectoral Sandpiper. Abundant at Manvers and Hopedale in August and September.

42. Tringa fusicollis. White-rumped Sandpiper. Abundant along the shore in August and September.

43. Tringa minutilla. Least Sandpiper. Rather common, breeding locally.

44. Ereunetes pusillus. Semi-palmated Sandpiper. Common, breeding locally. Young found on July 18 th, at Seal Island.

45. Calidris arenaria. Sanderling. Rather scarce. August and September.

46. Totanus melanoleucus. Greater Yellow-legs. Rather scarce, in August and September. Not found breeding.

47. Actitis macularia. Spotted Sandpiper. Very numerous, breeding almost everywhere.

48. Numenius borealis. Eskimo Curlew. Barely a remnant of their former numbers. Nearly exterminated. A few were seen during September, perhaps eight or ten.

49. Charadrius dominicus. Golden Plover. Rather Common. Sev- 
eral small flocks observed on and after August 2oth. Manvers and southward to Belle Isle.

50. Afgialitis semipalmata. Semipalmated Plover. Common, breeding along the whole coast.

5r. Lagopus lagopus. Willow Ptarmigan. Rather common from Hamilton Inlet north to Manvers.

52. Lagopus rupestris. Rock Ptarmigan. Common from Cape Harrigan northward. Beyond Okkak the rock ptarmigan probably belonged to the sub-species "reinhardti."

53. Archibuteo lagopus sancti-johannis. Rough-legged Hawk. Very abundant everywhere. Breeding commonly.

54. Falco rusticolus obsoletus. Labrador Gyrfalcon. Scarce. One at Port Manvers, September 5th.

55. Falco peregrinus anatum. Duck Hawk. Rather common at Port Manvers and northward.

56. Asio accipitrinus. Short-eared Owl. Rather common on the coast in September.

57. Otocoris alpestris. Horned Lark. Abundant everywhere. A very characteristic bird.

58. Perisoreus canadensis nigricapillus. Labrador Jay. Common locally as far as Port Manvers, where it was abundant.

59. Corvus corax principalis. Raven. Common from Hamilton Inlet northward. South of that, scarce.

6o. Pinicola enucleator. Pine Grosbeak. Common wherever we found woodlands, as far north as Mokkovik.

6I. Acanthis linaria. Redpoll. Everywhere common.

62. Plectrophenax nivalis. Snow Bunting. Abundant from August I5th on, especially at Manvers.

63. Calcarius lapponicus. Lapland Longspur. Abundant after August 3oth. Very numerous at Port Manvers.

64. Ammodramus sandwichensis savannah. Savannah Sparrow. Locally common. Abundant at Manvers from August 24th to September 5 th.

65. Zonotrichia leucophrys. White-crowned Sparrow. The most abundant land bird everywhere.

66. Spizella monticola. Tree Sparrow. Rather uncommon, though not rare.

67. Junco hyemalis. Junco. Not common. A few near Mokkovik early in August.

68. Melospiza lincolni. Lincoln's Sparrow. Common in the more southern region, as far as Hamilton Inlet. Breeds. 
69. Passerella iliaca. Fox Sparrow. Very common as far as Mokkovik. Breeds abundantly.

70. Dendroica coronata. Myrtle Warbler. Locally common to Mokkovik.

7r. Dendroica striata. Black-poll Warbler. Abundant as far as Hopedale. A very characteristic bird.

72. Seiurus noveboracensis. Water Thrush. Not uncommon as far as Mokkovik.

73. Anthus pensilvanicus. Titlark. Very abundant everywhere in the more barren regions and on the islands.

74. Regulus satrapa. Golden-crown Kinglet. Rather common in wooded places. North to Mokkovik.

75. Parus hudsonicus. Hudsonian Chickadee. Rare. Two or three at Manak.

76. Turdus aliciæ bicknelli. Bicknell's Thrush. One taken near Battle Harbor.

77. Turdus ustulatus swainsoni. Olive-backed Thrush. Rather common wherever there were trees, as far as Mokkovik.

78. Merula migratoria. Robin. Rather uncommon. Common at Manvers September 6th to 8th.

79. Saxicola œnanthe. Wheatear. The agent at Nachvak had nests of this bird, which he had taken.

\section{$\mathrm{X}$. \\ REPORT ON GEOLOGY. \\ BY REGINALD A. DALY, PH. D.}

The "Paradise of Geologists" is undoubtedly the great arid belt of the United States. The interpretation of the structure and history of the earth's crust is there possible with a degree of rapidity and an amount of assured detail which are scarcely possible in any other region of the globe. A chief cause for this facility of study is to be found in a very general lack of forest and even of the soil-cap, which so seriously interfere with the work of the observer elsewhere. This same condition is supplied also in the 
coastal belt of northeastern Labrador, and it is largely owing to the relative barrenness of this region that we were able to win geological results worthy of record even under such unpromising circumstances as those described in the log of the "Brave." To be sure, the numerous delays that were found necessary during the cruise formed a very considerable advantage to the geologist of the party, unwelcome as they generally were to his friends on board. At every anchorage something could be done toward sampling the problems which this coast has to offer. In every case, with no forest to obscure the view, attention could be quickly called to novelties, whether dike, lava flow, intrusive boss, peculiar schist, noteworthy structure, elevated beach or sea-cave. For this reason, the questions concerning the history and composition of the coastal belt grew in number and significance as we made our hasty reconnaisance, although most of them would be, of course, more or less distinctly in mind before one set out on the trip.

Composed as it is for the most part of the crystalline complex, presumably Archæan, which shows great diversity of structural trends where it has been studied by Low in the interior of Labrador, and by many others in its southern and southwestern extensions in Canada, it was not to be expected that the northeastern coast-line would show the same average parallelism to the strike-direction of the schists as appears in the relation of the coast-line from the Carolinas to the Straits of Belle Isle. I was, therefore, not a little interested to find that, at some twenty-five different points from the Straits to Nachvak Bay, there is a decided correspondence in the attitude of the bedded rocks. Their edges are directed approximately northeast-southwest, giv- 
ing a "Labrador trend" which meets the "Appalachian trend" nearly at right angles in the vicinity of Belle Isle. The Archrean plateau would seem, then, to be rather definitely rimmed for a distance of seven hundred miles on this northeast coast by the axis of the old mountain system. It is probable that the average direction of the present coastline and of the adjacent continental shelf has thus been roughly determined by a principal and fundamental line of mountain-folding.

So ancient is this orographic system that most of its height has long since been lost. Only in the belt stretching one hundred and fifty miles from the Johannisberg at Hebron to the cliffs of Cape Chidley is there a strong reminder in the existing relief of the Pre-Cambrian alpine chain. Orographically, though not structurally, this belt is a distinct unit and may be differentiated as the "Torngat" Range. The need of a special name for the range is evident to one who sees the great contrast between its lofty, rugged, oftentimes serrate topography, and that of the lower, monotonously rolling, hummocky plateau to the south. I have, therefore, adopted, with a slight modification of spelling (therein following the early missionaries, Kohlmeister and Kmoch), the name which Weiz gave to a part of the range.

A collection of the more typical rocks of the crystalline complex was made. Not the least interesting addition to this petrographical booty was the gabbro from which the famous iridescent feldspar "labradorite" was first obtained nearly a century ago. So far as I am aware, the beautiful specimens which may be seen in all the principal museums of the world have, without exception, been obtained from 
the glacial erratics which are plentifully strewn along the coast in the vicinity of Nain. The opportunity of collecting from the rock in place at Mr. Taber's quarry was highly prized. The microscopical and chemical diagnosis of this and other rocks in our summer's collection is not yet completed.

The Kaumajet mountain group not only affords some wonderfully beautiful scenic effects, but is to the geologist instructive as well. Ogua'lik, Cape Mugford, the Bishop's Mitre, are all part of an extensive area of slates, sandistones, conglomerates, limestones, and, much surpassing these in thickness, lava flows, volcanic tufts and breccias,-a series of well-bedded rocks which rest directly on the truncated edges of the gneisses of the crystalline complex. This "unconformity" between the gently dipping younger formation of sombre hue and the light gray gneissic basement is truly spectacular. The slightly sinuous line of contact between the two formations may be followed for miles on the bold cliffs in and about Mugford Tickle. It represents an ancient land-surface, buried now under twenty-five hundred feet of marine and volcanic strata of unknown but certainly great age. From this thick rock-blanket, atmospheric and glacial erosion have carved the picturesque Kaumajets as we see them to-day, while the same agencies have fashioned even more fantastic peaks and valleys in the gneissic basement at the Nanuktuks, where the rock-cover has been completely swept away.

During our two-weeks' stay at Nachvak Bay, I was able to construct a sketch-contour map of the inlet. and by a series of soundings to demonstrate that it is a true fiord and one of the best types in eastern America. With a maximum 
depth of 100 fathoms, it is not deep as fiords go, but the interruption of its bottom seaward slope by two rock-sills within the "Narrows" and the existence of a similar shoal outside show this bay to be of the same nature as the typical inlets of Norway, Greenland, or Alaska. The best interpretation of such an arrangement of bottom slopes would attribute them and the broad U-shaped cross-section of the fiord to glacial erosion. A corroboration of this view was found in a number of "hanging valleys" which are drained into the bay. It is now the fashion to regard these as indicating a power of excavation possessed by valley glaciers which was considered as highly improbable by most geologists only five years ago. One of these side-valleys is "hanging" some I,200 feet above the bottom of its trunk valley, Nachvak Bay, and at the junction of the two occurs the finest cascade in the region.

At Nachvak I was able to confirm Dr. Robert Bell in the proof that the glaciers of the ice epoch were only local in its closing stages, and that an overwhelming general glaciation of the Torngats, such as occurred in the White, Green, and Adirondack mountains, did not take place in the last glacial epoch. The ice of that period moved seaward from the névé of the interior of Labrador through the transverse valleys and passes of this range, and seldom, if ever, submerged the mountains above the 2, Ioo contour.

The glacial strix of the coast are scarcely more numerous than the "lunoid furrows" which had been discovered there by Professor Packard. Their characteristics led me to a somewhat new interpretation of these markings, which, however, I shall not detail here. They agreed with the strix in showing that the ice-movements of the last 
glacial epoch were radially outward from the centre of discharge, viz.: the southwestern portion of the peninsula. Baron De Geer has shown that with a similar dispersal of ice from the centre of the Scandinavian sheet, there may be correlated differential elevation of northwestern Europe in post-glacial times. This uplift of the continent has been greatest at the centre of radiation, and, in general, becomes progressively less with increasing distance from that centre. If, as seems natural, we may assume that the currents within the ice-cap moved from the centre outwards because the cap was thicker there than on the edges, it is legitimate to follow De Geer in forming his explanatory hypothesis of the correlation between ice-radiation and post-glacial elevation. Uplift has been most pronounced where the earth's crust has lost the greatest load by the melting of the ice-cap; less and less pronounced along the radii leading from the region of greatest thickness of ice. The earth's crust is, then, elastic, and sensitive to a load relatively so insignificant as a regional glacier.

De Geer saw that it would help his case if he could find a second example. He discovered that North America, while in the main telling the same story, could not furnish so complete a homologue on account of the lack of information regarding the maximum amount of post-glacial uplift in Newfoundland and Labrador. I was able to determine with a small margin of error the position of the highest postglacial shore-line from St. John's to Nachvak Bay, a distance of I, IOo miles. The result is to supply so much of a gap in the information necessary to test De Geer's theory; and, in the main, the theory is strengthened by this addition to the list of observations on crustal movements. Incidentally, 
barometric readings gave the elevations of a large number of raised beaches, sea-caves, etc., all exposed on the bare slopes with marvelous distinctness.

Some 300 observations of surface and subsurface temperatures of the coastal waters were made, and in many cases the densities were taken as well. These observations have not, as yet, been subjected to the necessary corrections nor has their significance been wholly determined.

A detailed account of my summer's results on the geology and physical geography of Labrador will shortly appear in a Bulletin of the Museum of Comparative Zoölogy, Harvard University. 



